\title{
〔第21回電気泳動学会春季大会講演抄録〕
}

\section{1. 尿中腎組織成分の臟器局在性について}

\section{成田 光陽・若新 政史 若新 洋子・東条 静夫 \\ (千葉大・医・第 1 内科)}

最近私共は尿蛋白分析の一環として, 尿中腎組織成分 の検索にこいて報告して来たが，その際かかる成分の他 䐃器成分之の類似性について 2,3 の質問が出されている ので，今回はそれらの質問に答觉る意味もあり，且つこ れらの成分の分析を行なう一段階として尿中腎組織成分 の他臟器との関連性について検討したので報告する.

方法としては度々のべて来た如く, 正常人尿約 $40 l$ を $4^{\circ} \mathrm{C}$ の条件下で $0.85 \%$ saline にて透析，Visking tube を 用いて陰圧法にて約 $1,000 \sim 1,200$ 分の 1 亿濃縮，乙れ を sample とした. 患者尿す同様操作により濃縮した.

人㛑尿細管上皮成分（RTE と略）の精製法としては正 常人腎組織（皮質）を $4^{\circ} \mathrm{C}$ の条件下で粗い mesh にて ホモジェナイズし，No. 180 の mesh を通して糸球体と 分離し, 3,000 回転, 15 分間遠心後, $0.25 \mathrm{M}, 2.2 \mathrm{M}$ の sucrose にて分離, 上方の浮上した物質を集め, trypsin 消化にて可溶性として抗原とした. この抗原を用い rabbit を免疫し抗尿細管上皮抗体を作製した．正常濃縮尿 は Sephadex G-200 にてゲル汇過を行なうと 3 個の分画 亿分かれるが，との FI, FII, F III 分画 夫々に対する抗 血清を rabbit にて作成し, 抗全濃縮尿, 抗 F I, F II, F III 血清とした.

この抗血清と各分画との関倸を見ると全濃縮尿では 2 本の沈降線を認め, うち 1 本は RTE 抗原と連続し尿成 分とはspur 形成する. 抗 FII 血清でも F II 抗原との 間に 2 本の沈降線を生じ，うち 1 本は RTE 抗原と連続 し spur を形成する．抗 F III 血清では RTE との間に沈 降線を生じな加た.

この様な正常尿中成分は患者尿中にも存在する．Ouchterlony 法にて center well に抗 RTE 血清を入れ，周 囲の well に RTE，ネフローゼ患者尿 3 名，正常血清を 入れ反応をみると, RTE, 患者尿とは 1 本の連続した沈 降線を生じ正常血清との閒には反応をみない，免疫電気 泳動上であ原点に近い部分に沈降線を生ずる。

尿成分は屡々非特異的沈降線を生ずるととがあるので, 抗血清を泳動し溝に患者尿を入れてみると，抗体領域に 沈降線を生じ抗原抗体反応による沈降物と考号られる. 以上の点より抗 RTE 及び抗正常尿血清を用いての結果 ではいずれも正常尿蛋白と尿細管上皮成分との閒には共 通成分の存在することが認められる。
さててれら尿中成分と他臟器成分との関連性について 蛍光抗体法（直接及び間接法）を用いて検討した.まず 抗 RTE 血清と人腎組織との結合では尿細管上皮内側に 明らかに特異辤光を認める. 抗正常尿血清であ尿細管上 皮に蛍光を認め共通成分の存在がわかる。との点は異種 の rat 尿細管上皮との結合をみてあ明らかに特異蛍光を もつ. 他臟器として消化管組織との結合を検討してみる 之，胃粘膜では抗尿細管上皮血清で腺組織の上皮にわず かに蛍光を認めるが，抗正常尿血清を用いてあ同様であ る。十二指腸ないし小腸を用いてみると，抗 RTE 血清 では小腸上皮辺縁に著明な蛍光を認め, これは抗正常 尿血清を用いても同様である．とれらの成績よりるると 小腸粘膜辺縁では尿細管上皮成分及び正常尿中成分の 3 者間住共通のものが存在するととがわかる．との場所は 小腸絨毛の表面即ち小皮縁部であり，電顕的には microvilli の多数存在する所である．尿細管上皮細胞の brush

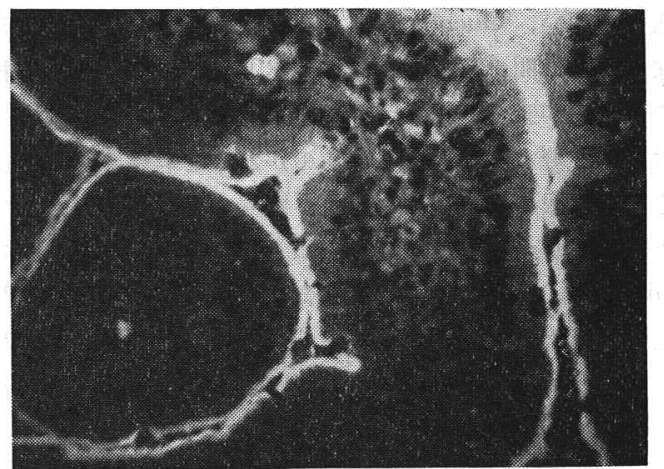

Fig. 1. Immunofluorescent pattern of normal duodenum stained with anti-human tubular epithelium rabbit serum.

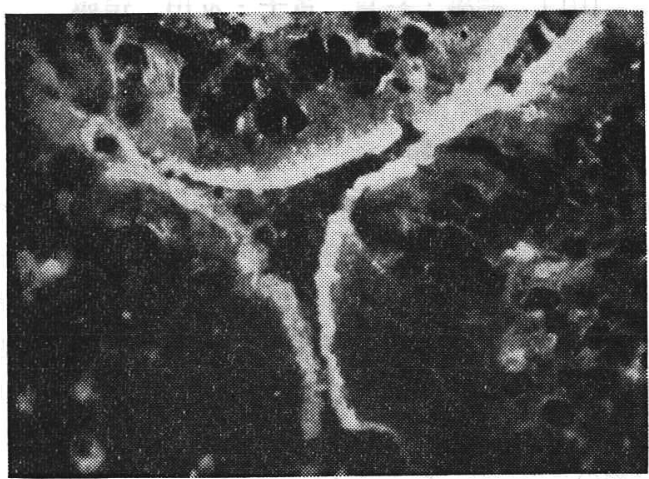

Fig. 2. Immunofluorescent pattern of normal duodenum stained with anti-human normal urine rabbit serum. 
boader 部位も電顕的には microvilli よりなっており， 構造的飞あ小腸粘膜小皮縁との類似性の強い所と考えら れ，とれら両者間に共通成分の存在するととも充分考慮 される (Fig. 1,2).

以上の成績より同様に形態学的に絨毛を有する胎盤組 織につき検討した. 人胎盤組織を抗 RTE 血清で染色し てみると，やや蛍光発色を示すが必ずしす特異蛍光とは 断定し難い．とれを抗正常尿血清で染色してみると明ら かに䋘毛の外側即ち syncytium（合胞体層）並びに結合 織の 1 部に蛍光を認める.との点は正常尿中組織成分は 尿中管上皮成分より抗原性に和いて広い物質を含むと之 を意味しており，また胎盤成分と尿細管成分との閒の共 通性は少ないととを意味している。

この点を更に確めるため, 胎盤より組織成分の分離を 試みた. 方法の概要は胎盤を mesh にて沪過, 遠心後上 清を trichlorosalicylic acid にて除蛋白後の上清を抽出 物とした，とのものを rabbit に免疫したが，との血清 と人胎盤組織との結合を蛍光抗体法でみると, syncytium 並びに絨毛の 1 部に特異的に蛍光を発する. との抗 血清を用い, Ouchterlony 法にて尿細管上皮成分と正常 尿蛋白との間の反応をみると， RTE との間には沈降線 をみないが正常尿蛋白との間には沈降線を生じ，尿中に は胎盤成分と共通性をあつものがあると考えられる．以 上我々は尿中腎組織成分の他, 臟器成分との共通性につ き検討を加えた. その結果尿細管上皮成分と小腸粘膜の microvilli，尿中物質の 3 者間には共通成分のあるととが 判明した．胎盤の䋐毛と尿細管上皮とには共通性は少な いが，尿中成分と胎盤成分との間には共通性の存在がみ とめられた。

\section{2. 尿中アミノ酸分析の検討}

\section{山口 春雄・嘉賀 章子・友田 恒典 （大阪医大・臨床病理・中検）}

\section{緒}

\section{늠}

尿中アミノ酸分析は先天性代謝異常疾患のみならず諸 種の病的状態の代謝を知るための 1 つの手段となる事は 云うまであない，血中アミノ酸值と同様尿中アミノ酸值 の分析は重要なあのであるが血中アミノ酸值に比してそ の報告は多くない，本報告では諸種の測定方法をあわせ て行ない, その長短について検討し, 又正常人尿中各ア ミノ酸の日内変動, 個人差について述べ, 又同様の検討 を正常ラットについても行ない，更に飢餓時におけるラ ット尿中アミノ酸の変動についても検討した.

\section{実験対象及びう法}

正常人，正常ラット，飢餓ラットを対象とした。

a) 高圧沪紙電気泳動法

$\mathrm{pH} 3.6$ の酢酸ピリジン緩衝液（蒸留水 99 , ピリジン 1, 酶酸 10), 汇紙は Whatman No. 1 を使用，試料塗布後 汇紙幅 $1 \mathrm{~cm}$ につき約 $5 \mathrm{~mA}$ の割で 30 分通電，乾燥後 ニンヒドリン反応を実施した。

b) 自動アミノ酸分析法

日立 KLA-3B 型の分析計を使用し，中酸性は $\mathrm{pH}$ $3.25,4.25$, 塩基性は 5.28 のクエン酸緩衝液を使用した。

c) アミノ酸窒素の測定は銅錯塩ヨード比色法にて行 なった.

d) アミノ酸標準液

ミドリ十字のアミノ酸標準液 $2.5 \mu \mathrm{mol} / \mathrm{ml}$ を 5 倍に 稀䣋して使用した.

\section{成績}

1) 方法について

まず標準アミノ酸を使用して分離を試みたととろ高圧 汇紙電気泳動法では塩基性, 中性, 酸性の 3 群にわりら れるが，中性のアミノ酸の分離が殆んど困難であったが 2 次元薄層クロマトグラフィーでは大体これらの分離は 可能であった (成績省略). 勿論定量的測定については自 動アミノ酸分析計が最もすぐれている事は云うまであな い.

自動アミノ酸分析法については尿の前処理が必要であ る. 即ち一定量の尿を苛性ソーダアルカリ性でアンモニ アを除去し，乙れを滅圧下で一旦濃縮し，塩酸酸性とし $\mathrm{pH} 2.2$ のクエン酸緩衝液で一定量とした。

2) 人尿中アミノ酸排泄の個体差

Table 1. は健常者の 24 時間尿中の各アミノ酸量, ア ミノ酸窒素量を測定した結果を示したが，A，B 健常者 間に各アミノ酸により多少異なるが相当の個人差を認め た. 又Aのみであ日により食慨その他種々の条件により

Table 1. Individual variation of urinary amino acid excretion in normal human subjects.

( $\mu \mathrm{mol} / \mathrm{Cay})$

\begin{tabular}{c|r|r|r}
\hline \multirow{2}{*}{ Variation } & \multicolumn{2}{|c|}{$\mathrm{A}$} & \multicolumn{1}{|c}{$\mathrm{B}$} \\
\cline { 2 - 4 } Amino acids & 1st day & 2nd day & \\
\hline Lysine & 1,530 & 440 & 810 \\
Histidine & 6,320 & 2,330 & 667 \\
Taurine & 1,950 & 2,230 & 1,058 \\
Glycine & 2,860 & 1,440 & 816 \\
Alanine & 950 & 610 & 312 \\
\hline
\end{tabular}


相当の差が認められた。 その他にも数種のアミノ酸, asparagin などが認められた。

又健常者についての 1 日中の各 6 時間ずつの尿につい てアミノ酸, アミノ酸窒素量を調べたが taurine (Tau.), lysine (Lys.), histidine (His.), alanine (Ala.) の順に又 8 p.m. 2 a.m. の間にその排泄量が多かった.

3）正常ラット尿中アミノ酸の変動

食慨その他を一定にするためラ゙ットについての実験を 行なった. 3 日間のアミノ酸窒素量を測定したが Fig. 1. の如く大きな変動を認めなかった.

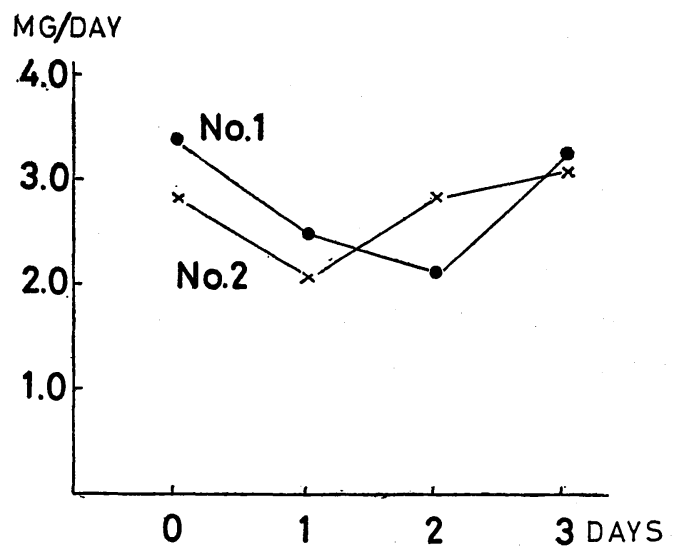

Fig. 1. Daily variation of urinary amino acid-N excretion in normal rats.

アミノ酸の種類についてもアミノ酸窒素と同じ傾向を 示した. 即ち Fig. 2. の如く排泄量の多い Tau., Gly., Ala., asparagin (Asn.) その他についてあ大きな日差を認 めなかった。

4）飢餓ラットの尿中アミノ酸の変動

3 匹のラットについて 8 日間の飢餓実験の結果は Fig.

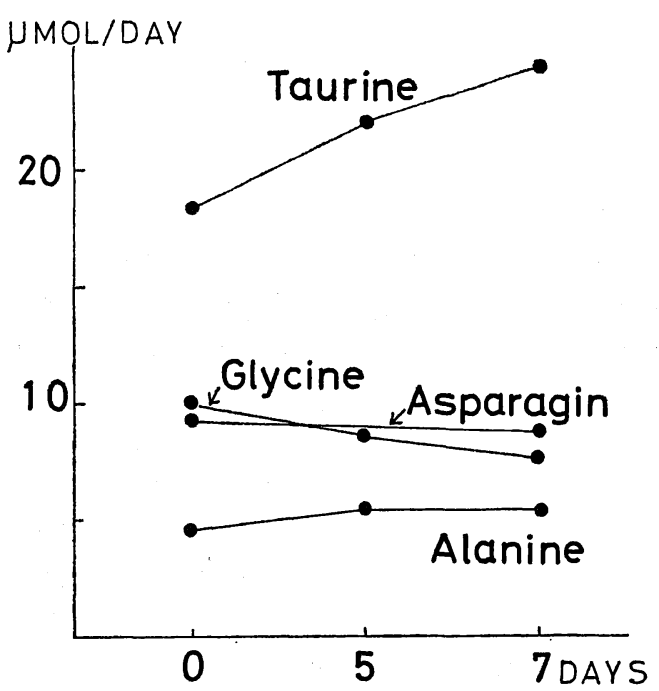

Fig. 2. Daily variation of urinary amino acid excretion in normal rats.

3. 亿示す如く，ラットにより少し type の異なるものも あったが，日数の経過ととあに明らかにアミノ酸窒素の 減少をみた。

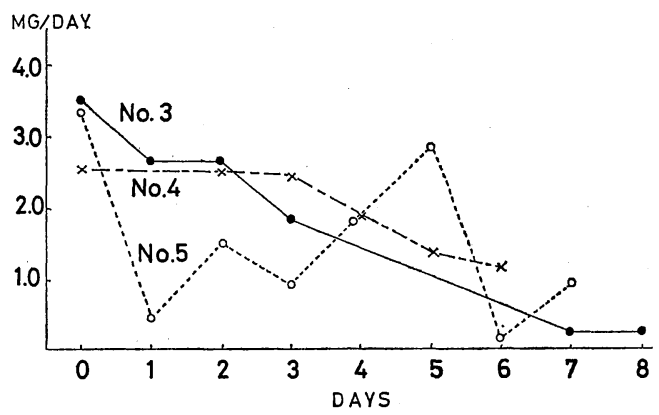

Fig. 3. Urinary anino-N excretion in fasting rats.

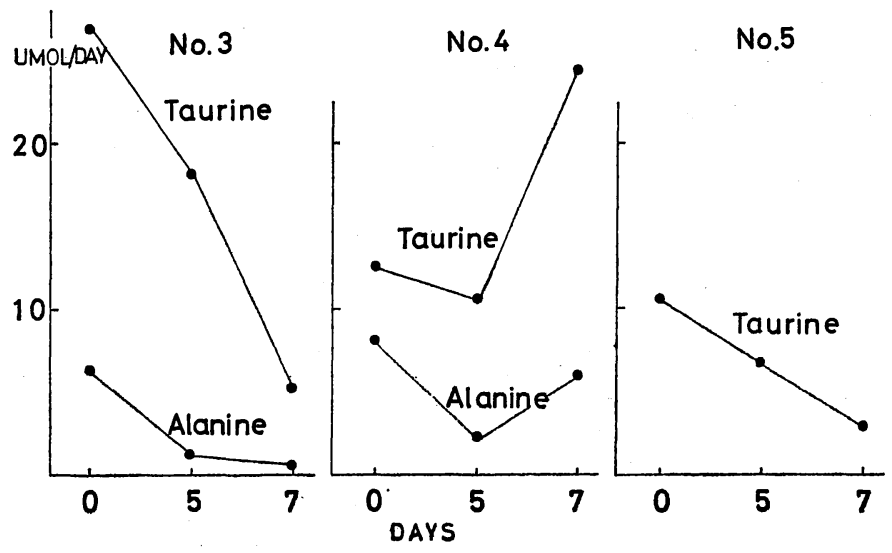

Fig. 4. Urinary amino acid excretion in fasting rats. 
アミノ酸の種類では Fig. 4. の如く, 例えば Tau., Ala. の排泄量は 1 例を除き明らかに減少傾向を示し，アミノ 酸窒素と同じ変動傾向を示した.

\section{総括}

高圧汇紙電気泳動法と自動アミノ酸分析法について我 々の経験から長短をみると, 勿論定量的目的には自動ア ミノ酸分析計に及ぶすのはないが，時間がかかる点とど の臨床検查室であ簡単に行なう事が出来ない点が問題で あり，との点定性的方法であっても簡易に出来るのは高 圧汇紙電気泳動法や各種クロマト法と考元られる。

又アミノ酸のみならずアミンの分析には高圧汇紙電気 泳動法の方が各種呈色試薬を使用して同定が可能であり， 我々はアミンの同定法に広くこれを応用している ${ }^{1)}$.

尿中アミノ酸排泄は 1 日中であかなりの変動があり, その濃度, 絶対量についても変動が観察されたのである から尿中アミノ酸濃度を論ずる場合 24 時間尿について 検討すべきであろう. 又同一人についても食餌の影響等 によって差があるからその変動についても考慮せねばな らない。

食餌の影響について検討中であるが今回は動物実験に て飢餓ラットの尿中アミノ酸濃度を検したが，アミノ酸 窒素の減少及び Tau., Gly., Ala. の著明な減少を認めた. 各種栄養状態之血液或は尿中アミノ酸值については多く の報告があり，最近では Landau $^{2)}$, Grimble $^{3)}, \mathrm{Adibi}^{4)}$ らの報告ああるが必ずしあ同一の成績ではなく，尚今後 くわしく検討すべき問題であると考えられる.
文献

1) 友田恒典他: 臨床病理, 13,637 (昭40).

2) Landau, R.L. et al.: J. Lab. Clin. Med., 72, 986 (1968).

3) Grimble, R.F. et al.: Lancet, 1, 918 (1970).

4) Adibi, S. A. et al.: J. Lab. Clin. Med., 77, 278 (1971).

\section{3. 頭部外傷時における䍔液蛋白の検討}

\section{友寄 英雄}

(久留米大・医・第 1 外科)

馬場 繁行

（久留米大・医・脳神経外科）

私共は頭部外傷の急性期及び亜急性期における髄液中 蛋白, 特に $\operatorname{IgA}, \operatorname{IgM}, \beta$-lipoprotein, fibrinogen につい て検討した。

とれ等の蛋白の検出には免疫電気泳動法及び Ouchterlony 法を用い，抗血清には Behringwerke 社製品を 使用した.

先ず，脳神経系疾患を有しない正常人 20 例の髄液に ついてとれらの IgA, IgM, $\beta$-lipoprotein 及び fibrinogen の有無を検討した芹, 免疫電気泳動法では上記の蛋白は 認められなかった. Ouchterlony 法についても同様に検 討した所, 13 例中 2 例 $(15.3 \%)$ に IgA を認めたが，他 の IgM, $\beta$-lipoprotein 及び fibrinogen は認められなか った.

Table 1. Disappearance of C.S.F. proteins after head injury.

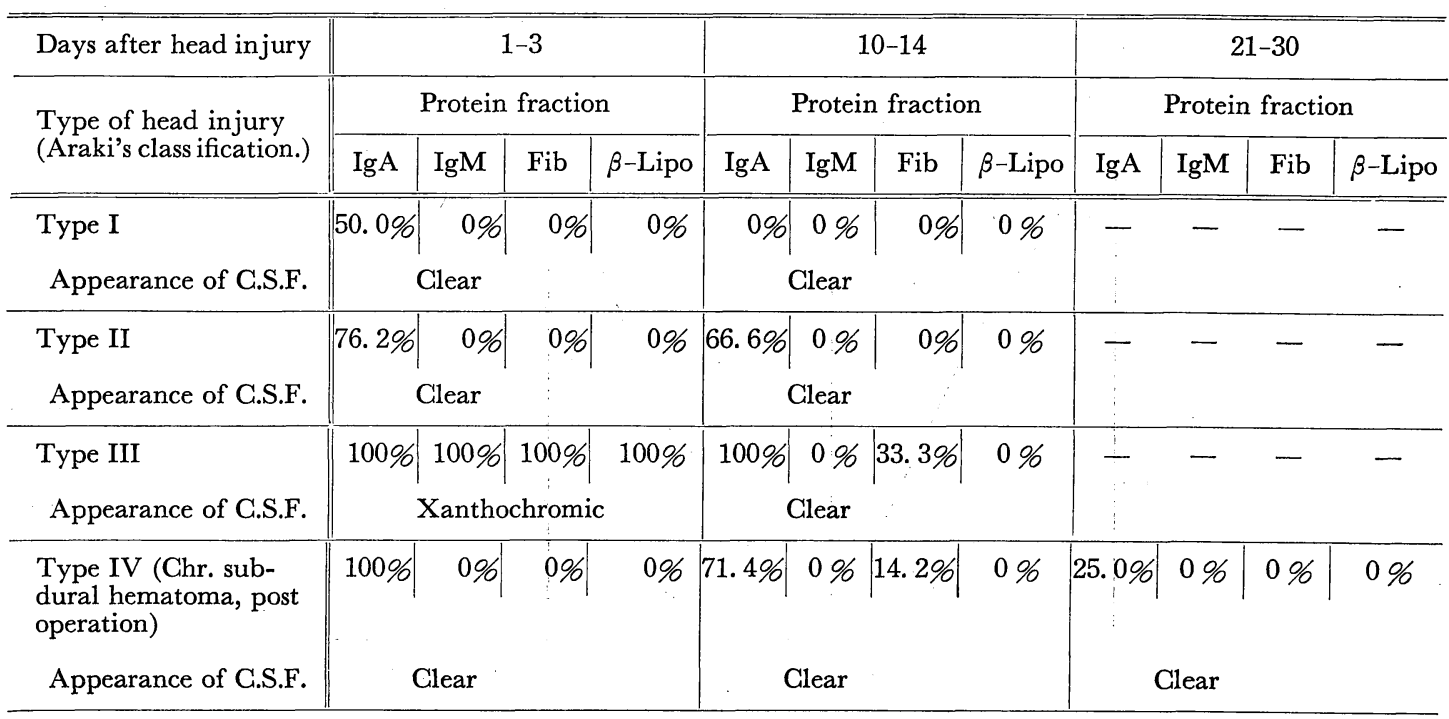

Ouchterlony method was used for the detection of protein fractions. 
そこで頭部外傷を荒木の分類に従い臨床的に第 I 型 (頭部外傷単純型), 第 II 型 (脳振盪型), 第 III型 (脳挫傷 型）及び第IV型（頭蓋内出血型）に分類し，それぞれ受 傷第 $1 \sim 3$ 病日を急性期, 第 $10 \sim 14$ 病日を亜急性期と し又 1 部では 21 日〜 1 ケ月後に区分し，それぞれ髄液 の採取を行なった。

その結果, 各頭部外傷型群の髄液蛋白の出現に Table 1.の様な変化を認めた。

すなわち頭部外傷 I 型群の急性期では IgA 6 例中 3 例 (50\%) 亿認めたが垔急性期では消失した.

頭部外傷 II 型群の急性期では 16 例中 12 例 (76.2\%) に IgA を認めたが，亜急性では $66.6 \%$ とわずかに減小し た. 又 $\operatorname{IgM}, \beta$-lipoprotein 及び fibrinogen については 頭部外傷 I 型群と同様に認められなかった。

頭部外傷 III型群では急性期の髄液は xanthochromia であり, IgA, IgM, $\beta$-lipoprotein 及び fibrinogen とも に 7 例中 7 例 $(100 \%)$ に認めた。亜急性では $\operatorname{IgA}$ はなお $100 \%$ に出現しているが fibrinogen は $33.3 \%$ に減少し, IgM, $\beta$-lipoprotein は出現しなかった。

頭部外傷IV 型群の慢性硬膜下血腫例では手術後早期に は IgA が 6 例中 6 例 (100\%) に認められたが. 時日を経 るに従い減少を示した。

以上の結果から IgA は正常人髄液中にあ微量ながら 存在し, 頭部外傷急性期においては髄液中に増加し易い ととを確認した。

特に臨床的には脳に器質的変化を伴わないとされてい る頭部外傷単純型や脳振盪型の急性期髄液中に $\operatorname{IgA}$ が 増加の傾向を示す事は臨床的にも興味深い.

\section{4. 赤血球電気泳動に関する研究} 一赤血球の大きさ, medium の 粘度, 誘電率の影響—

\section{戸塚 忠政・草間 昌三 \\ 田中貴・小野 隆彦}

(信州大・医・第 1 内科)

赤血球の大きさや， medium の粘度，誘電率により， 易動度やら電位, 電荷密度がどうかわるかを実験した。

\section{実 験 方 法}

泳動装置は Zeiss の cytopherometer に我々の工夫した 自動撮影装置をつけたあのであり，粘度の測定は Ostwald 型粘度計を用い，誘電率の測定は卓上型誘電率計 を用いた。 赤血球はO型で EDTA を用い採血後, medium で 1 回洗って泳動した. Medium のイオン強度は
0.043 で $\mathrm{pH} 7.2,2 \mathrm{~mA}, 22^{\circ} \pm 0.5^{\circ} \mathrm{C}$ ですべて測定した. 凝集赤血球は $\mathrm{A}$ 型赤血球にO 型血清を 32 倍に稀䣋した あのを加え, medium で 1 回洗って泳動した. $\zeta$ 電位の計 算は Pollack, W. らの式 $\zeta(\mathrm{mV})=\frac{1.006 \times 10^{7} \times \eta_{\mathrm{r}} \mathrm{U}}{\mathrm{D}}$ を 我々の測定条件に換算して用い，電荷密度の計算は $\mathrm{Ab}-$ ramson の式 $\sigma=\sqrt{\frac{N D K T}{2000 \pi}} \sqrt{\sum \mathrm{C}_{\mathrm{i}}\left[\exp \left(-\mathrm{Z}_{\mathrm{i}} \mathrm{e} \zeta / k \mathrm{~T}\right)-1\right]}$ を用いた。

\section{結果}

$3 \%$ ブドウ糖水溶液 3 容と standard saline phosphate solution（以下 S.S. と略す） 1 容の混合溶液中での泳動 では, 易動度Uの平均值は $1.470 \pm 0.049 \mu / \mathrm{sec} / \mathrm{V} / \mathrm{cm}$ で, 赤血球直径の平均は $8.0 \mu$ であった. この medium の比粘度 $\eta_{\mathrm{r}}$ は 1.048 , 誘電率 $\mathrm{D}$ は 80.0 である. これ より とは $20.84 \mathrm{mV}$ となり, 電荷密度 $\sigma$ は 3142.1 $\mathrm{ESU} / \mathrm{cm}^{2}$ となった. $5.4 \%$ ブドウ糖水溶液 3 容と S.S. 1 容の medium では, Uは $1.459 \pm 0.029$, 直径の平均值

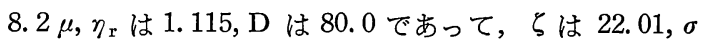
は 3330.3 となった. $10 \%$ ブドウ糖水溶液 3 容に S.S. 1 容の medium ではUは $1.389 \pm 0.070$, 直径の平均值

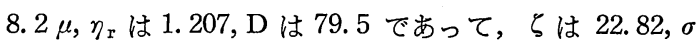
は 3460.4 となった. 次に medium の D を変えるべく デキストランを加えてみた. 平均分子量 228,000 の高分 子デキストラン $5 \%$ 水溶液 6 容に $5.4 \%$ ブドウ糖水溶 液 9 容と S.S. 5 容を加えた medium では, Uは $1.199 \pm$ 0.071 , 直径平均值 $8.2 \mu, \eta_{\mathrm{r}}$ は $1.839, \mathrm{D}$ は 78.0 であっ た. らは $30.60, \sigma$ は 4774.7 となった. 以上の 4 種類の medium では，個々の赤血球とその易動度を対比させた が，両者に相関を認めなかったので，赤血球を抗体を用 いて凝集させ，凝集塊の易動度を測定してみた。 $5.4 \%$ ブドウ糖水溶液 3 容に S.S. 1 容の medium で, 単一の 赤血球の易動度の平均值は $1.433 \pm 0.044$ であり，凝集 塊は $1.341 \pm 0.062$ であった。

\section{考察}

赤血球の大小により易動度が変るかどうかは, 1930 年代に Abramson らにより変化がないと結論されたが, 当時は写真撮影の応用はなかった. 我々は撮影により, ひとつひとつの赤血球との易動度を対比させたが，やは り一定の関係を認めるととができなかった.しかし凝集 塊のように極端に大きくなると, 易動度が低下するとと が観察されたが，とれには粘性抵抗や静止面や表面積等 の因子が作用しているあのと考えられる。

Medium の粘度は，易動度に対する影響はそれ程大き 
くはなく，く電位計算に対しては，大きく影響するとと がわかった．更にそのらより電荷密度を計算してあ同様 に大きな影響を受けた。 とのととは, medium の bulk viscosity がそのまま赤血球作用しないのであろうと考 えられる. Medium の誘電率については, Pollack らは デキストランで上昇したと報告しているが，我々は高分 子と低分子デキストラン水溶液で誘電率の上昇は認めな 加た。とれが，彼らとは測定器も測定周波数も異なる 点に起因するの加今後も追求して行きたい.

\section{結語}

1. 赤血球は個々の大きさと易動度とは関係はないが， 凝集塊は易動度を低下させる。

2. Medium の粘度はそれ程易動度に影響しない。

3. ブドウ糖やデキストランは水の誘電率をあまり変 化させないが，粘度は大きく変える。

4. $\zeta$ 電位之電荷密度の計算には medium の粘度が大 きく影響する。

\section{5. ヒトリンパ球の細胞電気泳動的研究}

\section{橋本 信也・佐々木勝久・鈴木 啓司 斉藤 裕子・前納 宏章・阿部 正和} (東京慈恵医大 $・$ 第 4 内科)

細胞電気泳動法を用いて細胞膜の表面荷電を測定する ことは, 細胞膜の構造や機能の解明飞役立つあのと思わ れる.とくに抗原抗体反応の場としての細胞膜の変化の 研究に本法を導入するととは興味深いととである。近年, リンパ球と免疫との関係について多くの報告が行なわれ ているが, 細胞電気泳動的考察については未だ十分な知 見がえられていない，今回，我々はまず正常ヒトリンパ 球と，少数例の病的白血球の電気泳動易動度定測定し検 討した。

用いた細胞電気泳動装置は杉浦研究所製, 細胞電気泳 動度測定顕微鏡 I 型である。泳動管を $25^{\circ} \mathrm{C}$ 亿維持する ため，ポンプにより恒温槽から水流を循環させている. 泳動管はU字型のガラス管よりなり，中央に直角に顕微 鏡を配置し，ガラス管内に細胞浮遊液を入れる。緩衝液 は M/10 veronal, $\mathrm{pH}$ 7.0, イオン強度 0.157 で泳動条件 は $3.5 \mathrm{~mA}, 35 \mathrm{~V}$ で静止面に浮遊した細胞が 1 目盛移動 するのに要した時間（秒）を測定する．細胞電気泳動易 動度は Donryu rat 赤血球の電気泳動易動度 $(1.15 \mu / \mathrm{sec} /$ $\mathrm{V} / \mathrm{cm}$ ，国立癌センター山田喬博士による）と比較する。 細胞は 1 検体につき 20 ケ測定し， 1 個の細胞は電流の 方向を変えるととにより，別々に測定し平均をとった．
リンパ球の分離は我々が既に histocompatibility test と しての microdroplet lymphocyte cytotoxicity test K用

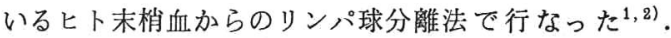
ナイロンファイバー・カラム法，3％ゼラチン法いず れあ，純度，viabilityにそれ程差はないが，細胞電気泳 動に用いるリンパ球調製む，3\% ゼラチン法で十分行 ないうることが判った。

ヒト正常末梢血リンパ球の cytopherogram を Fig. 1., Fig. 2. 亿示す. 第 1 例は $1.066 \mu / \mathrm{sec} / \mathrm{V} / \mathrm{cm}$, 第 2 例は 1.073 , 第 3 例は 0.927 , 第 4 例は 0.868 , 第 5 例は 0.975 , 第 6 例は 0.803 であるが，ここで判ることは，ヒト末梢 血リンパ球の電気泳動易動度に巾のあるととである，例 えば第 5 例は平均電気泳動易動度は 0.975 であってもそ の分布は 0.68 から 1.29 までに広がり, リンパ球の不均 一性を示唆するものと思われる. 同様にしてえられた 18 例の正常ヒトリンパ球の電気泳動易動度を Fig. 3., Table 1. 亿示す. 平均電気泳動易動度は $0.949 \mu / \mathrm{sec} / \mathrm{V} / \mathrm{cm}$ で, その S.D. $=0.174$ である. とれを諸家の報告と比較し てみると，Ruhenstroth-Bauer らは，1.009，Bart らは 0.93 あるいは $1.61,1.67$ と報告しており，我々の結果

\section{\#1 $1.066(\mu / \mathrm{sec} / \nabla / \mathrm{cm})$}

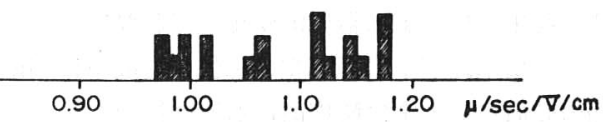

\#2 1.073

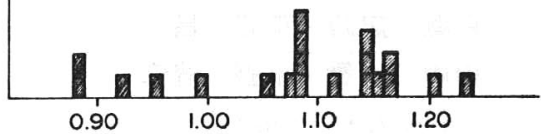

\# 30.927

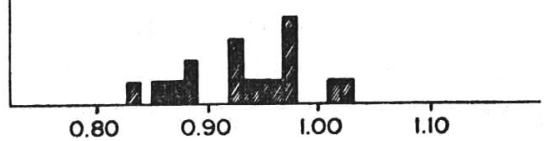

Fig. 1. Cytopherograms of 3 cases of normal human peripheral lymphocytes. 


\section{\# $4 \quad 0.868$}

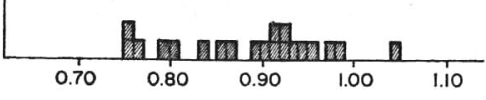

\# $5 \quad 0.975$

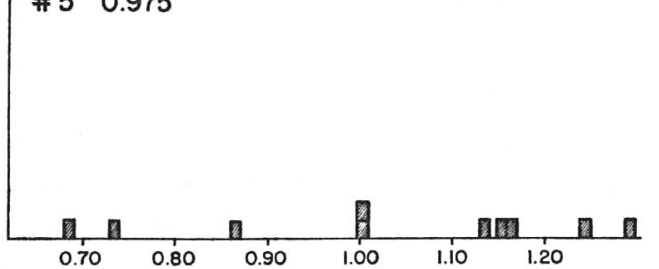

\# 6.803

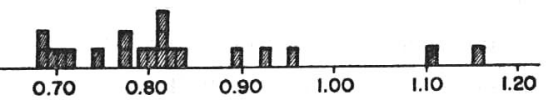

Fig. 2. Cytopherograms of 3 cases of normal human peripheral lymphocytes.

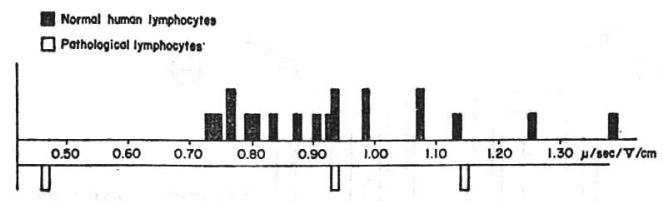

Fig. 3. Electrophoretic mobility of normal human lymphocytes.

Table 1. Electrophoretic mobility of normal human lymphocytes.

\begin{tabular}{c|c|c|c|c|c||c|c|c|}
\hline No. & $\begin{array}{c}\text { Mobi- } \\
\text { lity }\end{array}$ & S. D. & No. & $\begin{array}{c}\text { Mobi- } \\
\text { lity }\end{array}$ & S. D. & No. & $\begin{array}{c}\text { Mobi- } \\
\text { lity }\end{array}$ & S. D. \\
\hline 1 & 1.066 & 0.073 & 8 & 1.380 & 0.17 & 15 & 0.786 & 0.096 \\
2 & 1.073 & 0.097 & 9 & 0.837 & 0.11 & 16 & 0.703 & 0.094 \\
3 & 0.927 & 0.052 & 10 & 1.250 & 0.21 & 17 & 0.902 & 0.11 \\
4 & 0.868 & 0.076 & 11 & 0.920 & 0.12 & 18 & 0.926 & 0.072 \\
5 & 0.975 & 0.21 & 12 & 0.972 & 0.11 & 19 & 0.464 & 0.060 \\
6 & 0.803 & 0.12 & 13 & 1.130 & 0.01 & 20 & 1.150 & 0.11 \\
7 & 0.978 & 0.13 & 14 & 0.777 & 0.081 & 21 & 0.747 & 0.074 \\
\hline
\end{tabular}

Mobility and its S.D. are expressed in $\mu / \mathrm{sec} / \mathrm{V} / \mathrm{cm}$.

とほぼ一致する. 尚, 今回は少数例であるが, リンパ系 組織に病変を屯った患者の末梢りンパ球の細胞電気泳動 易動度についても調べてみた. 急性骨㵦性白血病 (62 才
女性）では 0.464 という極めて遅い易動度を示し，別の 急性骨髄性白血病 (29才女性) では 0.926 とほ活正常の

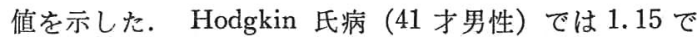
あった．とうした点については，未だ何ら結論的なとと は云元ず，例数をふやして，今後の検邻にまちたい，

\section{文献}

1) 橋本信也, 鈴木啓司, 横山三男：移植 4,61(1969).

2) 橋本信也, 鈴木啓司, 佐々木勝久, 斉藤裕子: 移植 5, 127 (1970).

\section{6. 流動パラフィンまたはデカリンを用いた セルロースアセテート膜の透明化につい $\tau$}

小川 㤎人

（国立遗伝学研・生化学遗伝部）

\section{小滝 寧男}

(東京慈恵医大・大平内科)

セルロースアセテート膜の透明化には, 流動パラフィ ンまたはデカリンが主として用いられている。その作用 は膜の気孔を満し，光の散乱を防ぐにあるとされていた から, 透明化の処理の条件について関心が薄かった.

ここでは，膜を乾燥しすぎたり，透明化処理が長すぎ ると，透明度の均一性をそとなうととを見いだしたので 報告する。

\section{実験}

実験は 2 部からなる，1つは処理時間について，他は 乾燥度に関する調查である。

用いた膜はセパラックス(製造番号 30350749)である.

1. 透明化処理時間：血清分画值を求めるときと同様 亿緩衝液，色素液および脱色液で処理してのち自然乾燥 せしめ, 流動パラフィンまたはデカリンに浸けて， 5,10 ， $20,30,40,50$ お。よ゙ 60 分目に透明度の均一性をみるた め, $1 \mathrm{~cm}$ 問隔で 5 力所の吸光度の差を求めた.

2. 膜の乾燥 : 前項と同じく前処理した膜を, $50^{\circ} \mathrm{C}$ に加温した，湿度 5 ないし $10 \%$ の空気を $2,4,6,8,10$ お よび 12 分間吹きつけて後, 透明化剂につけて, 透明度 の均一性を検定した，透明化処理時間は，前項の実験か ら, 流動パラフィン処理は 40 分, デカリンでは 10 分間 とした.

な拈，実施時の室温は $20^{\circ} \mathrm{C} \pm 5^{\circ} \mathrm{C}$, 湿度は $60 \sim 70 \%$ である。 
成績

1. 透明化処理時間：処理開始とと屯に透明度は次第 に平均化していく，しかしある時期を過ぎると，均一性 が乱れはじめる。透明度があっとあ均一となる時期は， 透明化剤によって異なり，流動パラフィンは処理開始後 40 分, デカリンでは 10 分目である.

2. 膜の乾燥 : 透明化剂の種類にかかわらず， 8 分間 熱風を吹きつけてから処理した例があっとも均一な透明 度を示す．それより乾燥時間が短くてあ長くてあ成績は 劣る.

\section{総括}

1. 透明化処理時間：いままでは膜を長時間透明化剂 の中に放置しておいても, 透明度の均一性にはさほに゙影 響がないと考えられていた。 しかし必要以上の長い処理 は好ましくないてとが判明した. 実用上すすめられる処 理時間は, 流動パラフィンで $30 \sim 50$ 分, デカリンでは 10〜20 分であろう.

2. 膜の乾燥：ことに行なわれた乾燥条件では, 透明 化剂の種類にかかわらず, 乾燥開始後 8 分間の処理例が あっとあ結果がよくこれにより乾燥が過ぎても, 不足で あ成績は劣る. 透明化前の膜は乾燥してもしすぎること はないと考えられていたが膜の乾燥度にも最適の条件が あるととが判った．なお，とこに行なわれた程度の加熱 で膜の変性は考元られない。

3. 流動パラフィンとデカリンとの透明化能に関す る比較 : 流動パラフィンに比べてデカリンは透明化を早 く完了できるし膜の乾燥条件にさほど成績が左右されな い，それゆえデカリンは多くの検体を処理できる点で優 れていよう.ただ, 処理時間が 30 分以上に及ぶと, 透 明度の均一性が悪化する点に注意しなければならない。

処理時間を長引かせないように注意すれば, デカリン が透明化冎として流動パラフィンより優れていよう.

\section{結論}

流動パラフィンまたはデカリンを用いたセルロースア セテート膜の透明化には, 処理される膜の乾燥状態や処 理時間に至適条件がある。

臨床検查室には, 処理時間の短いとと, 膜の乾燥条件 に余裕のあるととなどから流動パラフィンよりデカリン が適していよう。

\section{7. ポリビニルピロリドンを用いた電気泳動} 法による血清蛋白の分離

\section{牧正文・高原 光子・中村千恵子 \\ （日大・理工系・習志野校舎）}

本報告では, 可溶性の高分子化合物であるポリビニル ピロリドン (PVP) の濃度勾配を利用して, ヒト血清蛋 白成分を分離する新しい電気泳動分離法を紹介する. 用 いた PVP の分子量は比較的高いむので, その溶液はコ ロイド溶液を形成しており，その分子が血清蛋白のもの と近い場合には，てれが単に濃度勾配として㗢くだけで なく, いわゆる “分子篩” として作用して効果的な蛋白 質の分離が行なわれるあのである。

その方法は, Fig. 1. 化示すように，内径 $8 \mathrm{~mm}$, 高さ $30 \mathrm{~cm}$ のガラス製U字管を用い, とれに $\mathrm{pH}$ 8.6, 0.07 M の veronal buffer に $8 \%$ の濃度にPVPを溶解した溶液 を約半量流してんでから, U字管の右脚に, その上から LKB の gradient mixer を用いて, pH 8.6, 0.07 M の veronal buffer と，とれに $8 \%$ の PVP 溶解した溶液 とで作られた濃度勾配液を $14 \mathrm{~m} l$ 加えて濃度勾配層を作 る. この勾配の上部に $1 \%$ PVP 加 veronal buffer に溶

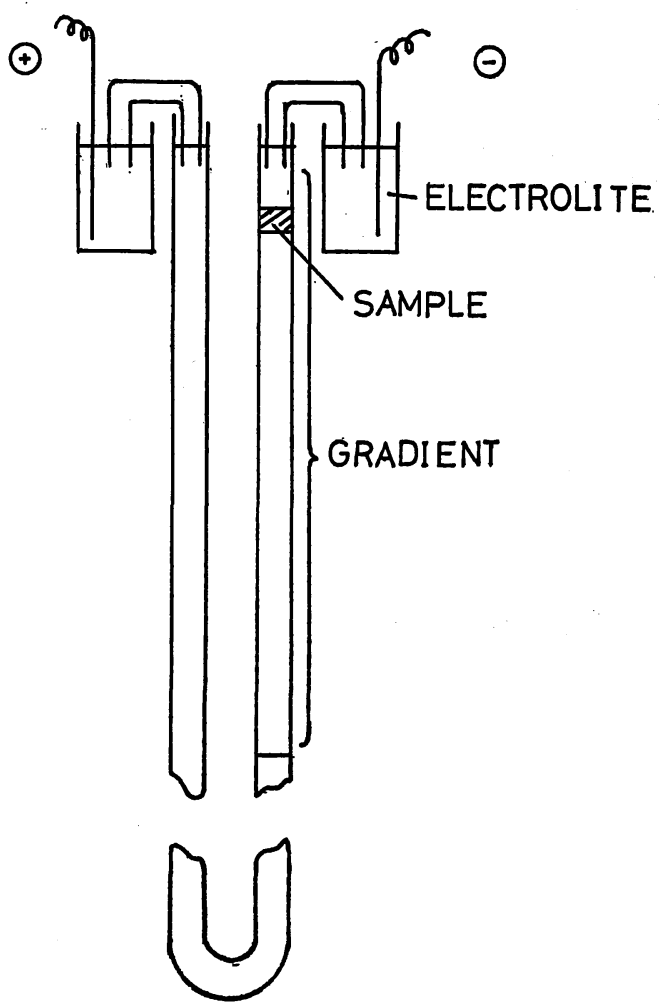

Fig. 1. The electrophoresis apparatus. 
解した血清試料を注入して分離試料とする，試料の詳細 な調製法は次の通りである.すなわち, 血清 $0.1 \mathrm{ml}$ に, $1 \% \mathrm{PVP}$ 加 veronal buffer 飞 $0.05 \%$ の濃度に BPBを 溶解した染色液 $0.2 \mathrm{~m} l$ を加えて蛋白を染色した溶液 $0.1 \mathrm{ml}$ をとって，とれに $1 \% \mathrm{PVP}$ 加 veronal buffer 0.1 $\mathrm{m} l$ を加兄て試料とする.

とのU字管を水槽中につけて温度を一定にし(約 $\left.22^{\circ} \mathrm{C}\right)$, 通常約 $350 \mathrm{~V}$ の直流電圧を $1 \sim 3 \mathrm{hr}$ 加けて泳動させる.

用いた PVP は 4 種で，分子量の小さいむのから K 15 (平均分子量 1 万), $\mathrm{K} 30$ (平均分子量 4 万), $\mathrm{K} 60$ (平均 分子量 16 万）および $\mathrm{K} 90$ (平均分子量 36 万）である. 分子量が大きくなるほど veronal buffer 汇溶解し難くな り, 溶解飞時間がかかる. K 90 の $8 \%$ の濃度のものは, ほぼ飽和に近い (Table 1.).

Table 1. The structure and molecular weight of PVP.

\begin{tabular}{|c|c|c|}
\hline The structure & No. & $\begin{array}{c}\text { Molecular } \\
\text { weight }\end{array}$ \\
\hline $\begin{array}{l}\left.\right|_{\mathrm{CH}} ^{\mathrm{CH}_{2}-\mathrm{CH}_{2}} \\
\left.\right|_{2} ^{\mathrm{CO}} \\
\cdots-\stackrel{\mathrm{N}}{\mathrm{C}} \mathrm{CH}_{2}-\cdots\end{array}$ & $\begin{array}{l}\text { K15 } \\
\text { K30 } \\
\text { K60 } \\
\text { K90 }\end{array}$ & $\begin{array}{r}10,000 \\
40,000 \\
160,000 \\
360,000\end{array}$ \\
\hline \multicolumn{2}{|c|}{$\begin{array}{l}\text { ( Serum albumin } \\
\text { ( Serum } \gamma \text {-globulin }\end{array}$} & $\begin{array}{r}70,000) \\
160,000)\end{array}$ \\
\hline
\end{tabular}

Alb (分子量 7 万),$\gamma$-glob（分子量 16 万）飞比較的 分子量が近い K 30 および $\mathrm{K} 60$ を用いた場合には，鮮鋭 な蛋日の分離が見られるが，K 15，K 90 を用いた場合に は効果的な分離は認められない，とれは分離される蛋白 質の分子量に PVP の分子量が近似している場合には, よくその “分子節作用”があらわれるととを示している.

Fig. 2. 亿は K 30, K 60 および比較対照のために PVP の代りに $8 \%$ の蔗糖の濃度勾配液を用いた場合の血清 蛋白の分離パターンを示してある.（血清蛋白の染色に用 いた BPB の過剩，すなわち free の BPB の部分の泳動 速度は, PVP 溶液中では極めて小さくなり, 先に泳動 する分離蛋白像に妨害を与えない，乙れは PVP のピロ リドン核の $\mathrm{CO}$ と色素の $\mathrm{OH}$ の間に水素結合が生ずる ためと解される.)

鷹梼の場合と比較すると, 全般的に分離峯が sharp に なっておりまた䓞糖の場合にみられなかった prealb の 部分に峯が 2 個と, alb の部分にいくつかの峯の重なり
のあるととが観測された，K60 の場合に分離峯は最も sharp になるという結果がえられた.

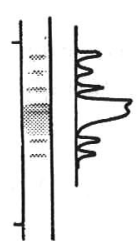

$\mathrm{K} 30$
$365 \mathrm{~V}$
$22.7^{\circ} \mathrm{C}$

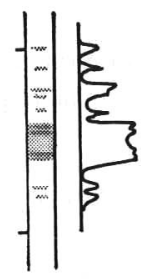

$\mathrm{K} 60$ $350 \mathrm{~V} 1 \mathrm{~h} 17 \mathrm{~m}$ $21^{\circ} \mathrm{C}$

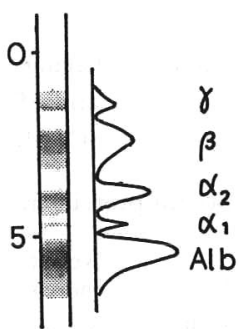

SAC $350 \mathrm{~V} 3 \mathrm{~h}$
Fig. 2. Separation of serum proteins on PVP gradient column.

\section{8. 高圧酸素環境下における血清蛋白質の変 動}

\author{
梅村 博也・久山 健 \\ (京大・医・第 2 外科)
}

上田 俊子

（京大・医・附属病院・中検）

京大医学部附属病院高圧酸素治療室で $1.5 \sim 2.0$ atmosphere absolute (ATA) の高圧酸素療法 (OHP) を施 行した 12 名の患者につき, 血液学的検查（赤血球数, 白血球数，ヘマトクリット，へモグロビン，血小板）㧊 よび血液化学検查 $(\mathrm{Ca}$, 無機 $\mathrm{P}$, 血糖, 残余垤素, 尿酸, コレステロール， アルカリフォスファターゼ， $\mathrm{LDH}$, GOT, 血清蛋白分画) を行なった.

Table 1. 飞 OHP 施行例を示した.

Table 1. List of cases studied.

\begin{tabular}{l|c}
\hline \multicolumn{1}{c|}{ Case } & No. \\
\hline Bürger's disease & 4 \\
Cerebral thrombosis & 2 \\
Head injury (III) & 2 \\
A-V malformation & 1 \\
DMP & 1 \\
Rainaud's disease & 1 \\
Radiation ulcer & 1 \\
\hline
\end{tabular}

OHP は 1.5 2 ATA で 1 時間空気加圧後に純酸素吸 入を行なった. 採血は OHP 施行前, OHP 施行中（純 酸素吸入開始後 40 分), および減圧後 20 分に行なった. 
検查項目中， OHP 施行中および施行後の值が, 施行 前值に比べて変化を示したのは血清蛋白分画值だけであ った.

Table 2. Change of serum protein fractions during and after oxygen high pressure therapy (OHP).

\begin{tabular}{l|l|ccccc|c}
\hline \hline \multicolumn{2}{c|}{ Serum protein fraction } & Alb & $\alpha_{1}$ & $\alpha_{2}$ & $\beta$ & $\gamma$ & A /G \\
\hline $\begin{array}{l}\text { During } \\
\text { OHP }\end{array}$ & $\begin{array}{l}\text { No. of cases } \\
\text { increased }\end{array}$ & 7 & 3 & 6 & 6 & 2 & 8 \\
$\begin{array}{l}\text { No. of cases } \\
\text { decreased }\end{array}$ & 7 & 11 & 8 & 8 & 12 & 6 \\
\hline After & $\begin{array}{l}\text { No. of cases } \\
\text { increased } \\
\text { OHP }\end{array}$ & 5 & 2 & 4 & 3 & 5 & 6 \\
$\begin{array}{l}\text { No. of cases } \\
\text { decreased }\end{array}$ & 7 & 9 & 7 & 7 & 7 & 6 \\
\hline
\end{tabular}

Table 4. Change of serum protein fractions during OHP.

\begin{tabular}{|c|c|c|c|c|c|c|}
\hline \multirow{2}{*}{ Case } & \multicolumn{5}{|c|}{ Serum protein fraction } & \multirow{2}{*}{$\mathrm{A} / \mathrm{G}$} \\
\hline & Alb & $\alpha_{1}$ & $\alpha_{2}$ & $\beta$ & $\gamma$ & \\
\hline \multirow{4}{*}{$\begin{array}{l}\text { Bürger's } \\
\text { disease }\end{array}$} & $\downarrow$ & $\downarrow$ & $\downarrow$ & $\downarrow$ & $\downarrow$ & $\downarrow$ \\
\hline & $\uparrow$ & $\downarrow$ & $\downarrow$ & $\downarrow$ & $\downarrow$ & $\uparrow$ \\
\hline & $\uparrow$ & $\downarrow$ & $\downarrow$ & $\uparrow$ & $\downarrow$ & $\uparrow$ \\
\hline & $\downarrow$ & $\downarrow$ & $\uparrow$ & $\uparrow$ & $\downarrow$ & $\uparrow$ \\
\hline \multirow{2}{*}{$\begin{array}{l}\text { Cerebral } \\
\text { thrombosis }\end{array}$} & $\downarrow$ & $\uparrow$ & $\uparrow$ & $\uparrow$ & $\uparrow$ & $\downarrow$ \\
\hline & $\uparrow$ & $\downarrow$ & $\uparrow$ & $\downarrow$ & $\downarrow$ & $\uparrow$ \\
\hline \multirow{4}{*}{$\begin{array}{l}\text { Head } \\
\text { injury } \\
\text { (III) }\end{array}$} & $\downarrow$ & $\downarrow$ & $\downarrow$ & $\uparrow$ & $\downarrow$ & $\downarrow$ \\
\hline & $\downarrow$ & $\uparrow$ & $\uparrow$ & $\downarrow$ & $\uparrow$ & $\downarrow$ \\
\hline & $\downarrow$ & $\downarrow$ & $\uparrow$ & $\downarrow$ & $\downarrow$ & $\downarrow$ \\
\hline & $\downarrow$ & $\uparrow$ & $\uparrow$ & $\uparrow$ & $\downarrow$ & $\downarrow$ \\
\hline $\begin{array}{l}\text { A-V mal- } \\
\text { formation }\end{array}$ & $\uparrow$ & $\downarrow$ & $\downarrow$ & $\downarrow$ & $\downarrow$ & $\uparrow$ \\
\hline DMP & $\uparrow$ & $\downarrow$ & $\downarrow$ & $\downarrow$ & $\downarrow$ & $\uparrow$ \\
\hline $\begin{array}{l}\text { Rainaud's } \\
\text { disease }\end{array}$ & $\uparrow$ & $\downarrow$ & $\downarrow$ & $\downarrow$ & $\downarrow$ & $\uparrow$ \\
\hline $\begin{array}{l}\text { Radiation } \\
\text { ulcer }\end{array}$ & $\downarrow$ & $\downarrow$ & $\downarrow$ & $\uparrow$ & $\downarrow$ & $\uparrow$ \\
\hline
\end{tabular}

血清蛋白分画に関する結果を Table 2., 3., 4. および Fig. 1. に示した.

Table 2. は各血清蛋白各分画百分率が増加したあの及 び減少したあのの例数である.

Table 3. は, Table 2. に示した各蛋白分画百分率の増 加および減少例について, 分画百分率の堌加率および減 少率を求めたものである.

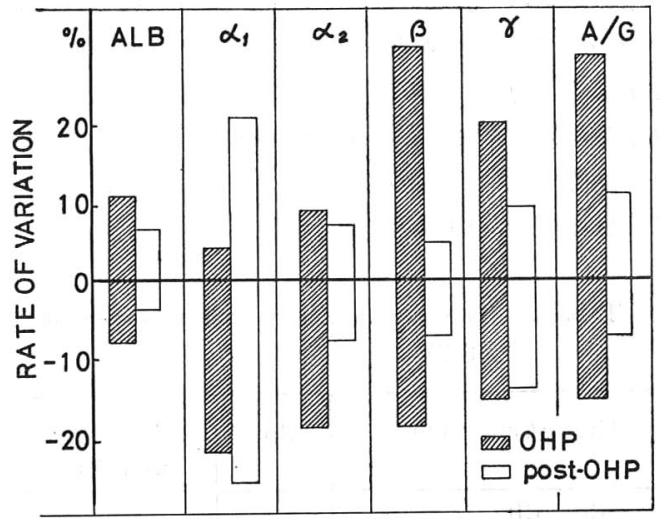

Fig. 1. Variation of serum protein fraction during and after hyperbaric Oxygen therapy.

Table 4. は各症例について, OHP 施行中の血清蛋白 分画濃度（総蛋白濃度に分画百分率を掛けてもとめたも の）の増加および減少を示したあのである. Fig. 1.は上 述と同様にしてえられた蛋白分画濃度が増加したものと 減少したものに分けて, OHP 施行中および施行後の増 加率および減少率の平均を示したものである.

これらの図および表からみられるように，OHP 施行 中および施行後の蛋白分画の全例に共通した変化は認め られなかったが， $\alpha_{2}$-glob および $\gamma$-glob 濃度は，14 例 中それぞれ 11 例および 12 例で減少を示した. この原因 については高圧酸素環境下というストレスにより生ずる 血清リポ蛋白执よび糖蛋白の減少ではないかと考えて検 討中である。

Table 3. Rate of variation of serum protein fractions.

\begin{tabular}{l|c|rrrrrr|r}
\hline \multicolumn{2}{c|}{ Serum protein fraction } & Alb & $\alpha_{1}$ & $\alpha_{2}$ & $\beta$ & $\gamma$ & A/G \\
\hline During & Average increase & 11.37 & 3.76 & 8.8 & 32.57 & 19.0 & 30.06 \\
OHP & Average decrease & 8.28 & 22.7 & 18.42 & 14.63 & 13.68 & 15.04 \\
\hline After & Average increase & 5.71 & 20.33 & 6.73 & 4.92 & 8.32 & 11.81 \\
OHP & Average decrease & 4.49 & 26.44 & 8.75 & 8.43 & 12.08 & 7.46 \\
\hline
\end{tabular}

Figures are in per cent of the control (pre OHP). 


\section{9. カルボールを用いる pre $\beta$-リポ蛋白の 1 検出法}

\section{山畑阿良太・宗像醇}

（日本医大・第 1 病院・皮膚科）

カルボールのようなフェノール核を有する物質を血清 に加えると, 脂質と結合している蛋白がてれと反応して 混濁を生じる. 実際, カルボールの食塩水溶液に血清を 混ぜた時に生ずる混濁は近似的に血清総脂質濃度に比例 し, Kunkel (1948), 柴田, 井内(1955) らにより phenol turbidity test として発表され，肝機能検查法として応用 されている.

一方当教室において，Kunkel と時を同じくして宗像 ら(1948)がカルボール反応を発表した.との反応は $0.5 \%$ カルボール生食水を用いる重層法による白濁反応で, 結 核患者血清にほぼ選択的に反応しその臨床的, 免疫血清 学的研究む数多く報告されているが, まだての反応の本 態を明らかにしたあのはない。

Phenol 混濁試験が血清の総脂質濃度に比例するとと から肝機能検查を目的とし, 宗像等の $0.5 \%$ カルボール 反能が結核血清と特異的に反応するなど，同じくカルボ ールを用い，同様に白濁反応でありながら全く検査対象 が異なるのは興味深い。

我々はこのカルボール反応を電気泳動的に研究してい る際, agarose gel 用いた電気泳動法で血清を分画した gel を, カルボール生食水に浸すと, 数分で血清脂質蛋 白が鋭敏にカルボールと反応して，透明な gel 内に明瞭 な白濁を生じるのを知った. 白濁は最低カルボール濃度 $0.4 \%$ より $\beta$-glob 域に認められるが， $2 \%$ 濃度では 3 分画 $\left(\alpha_{1}-\right.$ glob 域および $\beta$-glob 域の易動度の大きい部分 とそれより遅い部分の 2 分画）に白濁帯が生じる. 同条 件で泳動した試料を Sudan black B でリポ蛋白染色を 行ない比較検討し，更に白濁した gel を 2 日間水洗を行 ない白濁に関与しない蛋白を洗い流した後リポ蛋白染色 を行なっても白濁部分が染色される，などの事実より， 白濁を呈する分画はそれぞれ $\alpha$-リポ, $\operatorname{pre} \beta$-リポ， $\beta$ リポ蛋白に他ならないことが判った。

これらのリポ蛋白の白濁は, 反応する最低濃度が異な り一般に $\beta, \operatorname{pre} \beta, \alpha$ の順に反応するが, 反応時閒が早 いあのほど強く白濁することからあ，とれはそれぞれの 量的な違いによるあのと考える.

次で, リポ蛋白と無関係な $\gamma$-glob 域に白濁を呈した 症例があったので報告した。との白濁はリポ蛋白による あのと異なり，2 日間の水洗いで完全に消失した，島尾 はきわめて稀ににみられる蛋白質の固定剂による $\gamma$-域
の白濁を, それらの固定液の屈折率より分析し, 屈折率 が 1.36 より大きい時に明睹な白濁帯が観察され，1.35 以下では白濁はみられないという. 我々のカルボールに よる $\gamma$-glob 域の白濁は $0.75 \%$ 以上で観察されたが， $1 \%$ カルボール生食水の屈折率は 1.33 を示し, 島尾の 報告による白濁の生じる最低限よりはるかに低い屈折率 であり．我々のカルボールの $\gamma$-域白濁が単に屈折率の 点からは究明し得なかった。

近時，Fredrickson 等の広範な研究にともない，高脂 血症をその特有なリポ蛋白像により彼等の分類した 5 型 に分けて観察するととが一般化してきた．方法としては Lees and Hatch の alb 加緩衝液による沪紙雪気泳動法 が用いられ，との分類の基準となっている.しかしとの 分類にあたって最も重要な pre $\beta$-リポ蛋白の分離性や再 現性の問題, 泳動像の保存性, 血清量, 泳動時閒などの 立場から欧米では最近 agarose gel が多く用いられてい るという.

以上の事実から考えて，我々の行なったカルボールに よる agarose gel 内のリポ蛋白の白濁反応は, 反応が迅 速で，しかも染色，脱色なご繁雑な操作をしなくても直 視下に反応の進展が観察出来，特に pre $\beta$ - と $\beta$-リポ蛋 白が明瞭に分離するなど，今後さかんとなると思われる $\operatorname{pre} \beta$-分画の検索に，十分利用できる方法であると考え 報告した.

\section{0. 交叉兔疫電気泳動法の基礎的検討}

\section{鈴田 達男・平良 実 \\ （東京医大・血清学）}

免疫電気泳動法には血漿蛋白などの複雑抗原の解析に 便利な方法であるが，通常の方法では定量的な意味づけ は一般的に困難で，大まかな変動を推測しうるに過ぎな い.

この定量化については Libich (1959), Backhausz ら (1959), Ressler (1960), Bolewski (1960), Ouchterlony (1961) などにより，一旦泳動後抗血清を構に入れて両因 子搪散をおこさせる代りに，抗血清を含む寒天ゲル中に 単純拡散をさせる方法が試みられ，日本では右田(1970) の報告がある.

一方 Laurell (1966) によって工夫された交又免疫電気 泳動法は，抗血清を含ませた寒天中に抗原を泳動させ， その泳動距離によって抗原量を知る点が特徴であるが， 抗原之抗体の量的関係の他種々の因子によって泳動距離 は大いに影響されるので, 通常の免疫電気泳動法以上に 条件の一定化が要求される. 


\section{（98）生物物理化学}

ととろが従来の交又免疫電気泳動法では，1 次元の泳 動を行なった寒天片を $90^{\circ}$ 回転させた後, 抗血清入りの 寒天を同じ厚さに固める必要があり，乙の際に泳動軸が 曲ったり，位置がずれたり．或は厚さが不整になるなど の欠陷をあっていた.

われわれはさきに通常の免疫電気泳動法において，ブ リッジ式の装置をむちいる独特の方法を考案してよい成 績をえているので，乙れを応用して新しい手技の開発を まず試みた。

すなわち，アクリル樹脂製のブリッジ式泳動枠にガラ ス板を敷き， 1 次元泳動用の鋳型をむった蓋をして，ビ ニールテープで目張りする，とれに溶解した寒天を注い で固化させ， 巾 $1 \mathrm{~cm}$ の細長い寒天片を作り，抗原を注 入して 1 次元の泳動を行なう. 泳動終了後, 2 次元用の 枠にガラス板をのせ，乙の上に今の型枠を逆さにして， しかむ $90^{\circ}$ 回転させて背中合わせに重㸚合わせ，ビニー ルテープで前回同様に合わせ目に目張りをする．とれを 再びひっくり返して寒天と抗血清とをまぜたものを脚の 部分から入れて抗体寒天層を作る. この際にガラスとガ ラスの間の空気を抜いて寒天の進入を助ける，乙れを再 び裏返して 2 次元の電気泳動を行なう.

とうするととによって，1 次元の泳動後, 寒天片の位 置をかえるととなく直ちに抗体入りの寒天層を厚さをそ ろえて一定作ることができ, 電気抵抗が一定となるの で泳動条件を一定にするととができる。

ウサギの血清と対応するウマの抗血清を用いてとの方 法を検討したととろ，きれいな沈降線の発現をみとめた．

抗原と抗血清の濃度をいろいろにかえた組合せを作り， 定量性をしらべたところ，適当な抗血清濃度をえらべば， 濃度の対数と泳動距離にほぼ直線関係が成立つととがわ かった.

しかし複雑抗原の場合に，すべての分画についてとの ような関係が成立つわけではないので，抗原の孔を 1 次 元泳動軸の方向に 2 つけり，一方に標準品を大れて他方 の穴の検体との間に reaction of identity でつながらせ, その相互の比をとる方が望ましい.

しかし，交又泳動法はその原理から明らかなように， 易動度のお之い分画, ととに免疫 glob の定量には不向 きである．乙の目的のためにはどうしても泳動後の単純 拡散法 (Libich 法) か, 又は Peters ら (1960), Vasileisky (1959) の 3 次元免疫電気泳動法によらなくてはならない. そこで，乙の手技を応用して 2 次元の電気泳動を抗体 を含まない寒天中で行なった後上部のガラス板をはずし て抗血清入りの寒天を流して固化させ, 上下方向へ両因 子拡散をおこさせると輪状の沈降線を生ずる.

この方法によれば $\gamma$ 領城の分画測定にも用いるととが
でき，又 2 次元泳動の終了後特殊染色によって分画の同 定を行なっておくことが可能であるが．検出感度は交又 泳動法より劣る欠点がある。との面積と抗血清, 抗原濃 度との関係については現在検討中である。

\section{Double-antibody electrosyneresis について}

\section{石黒 達也}

（専売公社京都病院・産婦人科）

村中日出夫

(同上・内科)

通常の寒天電気泳動法では, $\gamma$-glob は陰極側に泳動し, alb, $\alpha$-glob, $\beta$-glob は陽極側に泳動する．乙の原理を免 疫沈降反応に応用して，Bussard, A. (1959) は “l'électrosynérèse (electrosyneresis)” を発表した. 本邦でも“Counterimmunoelectrophoresis” あるいは “免疫電気浸透法” と呼ばれ，近年 $\mathrm{Au}$-抗原や $\alpha$-fetoprotein の検出に広く 応用されている. 本法は，免疫沈降反応を 15-30 分で 検出する事が出来る利点を有しているが，その感度は Ouchterlony 法にやや優るとはいえ，寒天の電気浸透に 影響され易く, Ouchterlony 法に比べて著しい差は認め られなかった。

今回我々は人血清 alb と家鬼抗 alb 血清の沈降反応 系に，家鬼 $\gamma$-glob に対する山羊抗血清を導入する事に よって, 従来の electrosyneresis より更に微量の抗原を 検出する事が出来たのでこの手技を double-antibody electrosyneresis (DAE) と名付け，報告する.

抗原には人結晶 alb (Sigma Chem. Co.) を用い，抗体 には alb で免疫して得られた家鬼血清, 並びに家鬼 $\gamma$ glob に対する山羊抗血清 (Farbwerke Hoechst, AG.) を 用いた. Electrosyneresis はベロナール緩衝液， $1.5 \%$ 寒 天ゲルを用いて行ない，DAE は 15 分間の electrosyneresis 後陽極側に家鬼 $\gamma$-glob に対する抗血清を加えて, 更に 15 分泳動する事によって行なった. Electrosyneresis, DAE 共に毎回人血清及び馬血清をそれぞれ positive control, negative control とし, 抗原, 抗体の希釈は生理 的食塩水によって行なった.

倍数希釈した alb を抗原に，希釈しない抗血清を抗体 に用いて micro-Ouchterlony 法, electrosyneresis, DAE それぞれにおいて沈降線の出現する最高希釈の抗原量を 測定すると Table 1. の如く, electrosyneresis, DAE で は $6.25 \mathrm{mg} / \mathrm{d} l$ 迄明らかな沈降線が生じた. 一方 microOuchterlony 法では $12.5 \mathrm{mg} / \mathrm{d} l$ 迄は明瞭な沈降線が出 現したが， $6.25 \mathrm{mg} / \mathrm{d} l$ では極く薄い沈降線しか生じな 
Table 1. Comparison of semiquantitative determination of albumin by micro-Ouchterlony technique, electrosyneresis and double-antibody electrosyneresis, using nondiluted antibodies.

\begin{tabular}{c|c|c|c}
\hline \hline \multirow{2}{*}{$\begin{array}{c}\mathrm{Alb} \\
(\mathrm{mg} / \mathrm{d} l)\end{array}$} & \multicolumn{2}{|c}{ Appearance of precipitation zone } \\
\cline { 2 - 4 } & $\begin{array}{c}\text { Micro-Ouchter- } \\
\text { lony technique }\end{array}$ & Electrosyneresis & $\begin{array}{c}\text { Double-anti- } \\
\text { body electro- } \\
\text { syneresis }\end{array}$ \\
\hline 12.5 & + & + & + \\
6.25 & - & + & + \\
3.125 & $(+)$ & - & - \\
\hline
\end{tabular}

かった. 然し以上の如く，希釈しない抗血清を用いた場 合, micro-Ouchterlony 法, electrosyneresis, DAE それ ぞれの感度には特に著しい差を認めなかった。

次に抗 alb 家兔血清を倍数希釈し, 沈降線が出現する

Table 2. Final dilution of antiserum against albumin which gave precipitation zone in electrosyneresis and double-antibody electrosyneresis.

\begin{tabular}{c|c|c}
\hline \hline \multirow{2}{*}{$\begin{array}{c}\text { Alb } \\
(\mathrm{mg} / \mathrm{d} l)\end{array}$} & \multicolumn{2}{|c}{$\begin{array}{c}\text { Final dilution of antibody against alb. with } \\
\text { precipitation zone }\end{array}$} \\
\cline { 2 - 3 } & Electrosyneresis & $\begin{array}{c}\text { Double-antibody } \\
\text { electrosyneresis }\end{array}$ \\
\hline 500 & $1: 16$ & $1: 128$ \\
100 & $1: 16$ & $1: 128$ \\
10 & $1: 64$ & $1: 512$ \\
\hline
\end{tabular}

Rabbit anti-alb. serum was diluted by double dilution technique with saline.

Non-diluted goat antiserum against rabbit $\gamma$-glob was used as the additional antiserum.

抗体の最高希釈倍数を electrosyneresis, DAE の両者で 比較した. 本実験では，抗家鬼 $\gamma$-glob 血清は希勫せず， 抗原 alb 量は $500 \mathrm{mg} / \mathrm{d} l, 100 \mathrm{mg} / \mathrm{d} l, 10 \mathrm{mg} / \mathrm{d} l$ の 3 系列 について成績を比較検討した. Table 2. に示す如く， electrosyneresis, DAE 共に抗原量が少なくなるに従い高 希釈抗血清でも沈降線が出現した. 然し, 抗原が等量の 場合には，沈降線の出現する抗体の最高希釈倍数は明ら かに DAE の方が高い. 換言すれば，DAE を用いれば 高希釈の抗血清を用いても, 同量の抗原を検出する事が 出来る.

次に 64 倍希勫の抗 alb 血清, 及び非希釈抗家鬼 $\gamma$ glob 血清を用い, electrosyneresis DAE それぞれの方法 で検出し得る最少 alb 量を求めると, Table 3. の如く, electrosyneresis では $4 \mathrm{~m} \mathrm{~g} / \mathrm{d} l$ であったのに対し， DAE
Table 3. Semiquantitative determination of albumin by electrosyneresis and double-antibody electrosyneresis using diluted antiserum against albumin and non-diluted antiserum against rabbit $\gamma$-globulin.

\begin{tabular}{c|c|c}
\hline \multirow{2}{*}{$\begin{array}{c}\text { Alb } \\
(\mathrm{mg} / \mathrm{d} l)\end{array}$} & \multicolumn{2}{|c}{ Appearance of precipitation zone } \\
\cline { 2 - 3 } & Electrosyneresis & $\begin{array}{c}\text { Double-antibody } \\
\text { electrosyneresis }\end{array}$ \\
\hline 10 & + & + \\
7 & + & + \\
6 & + & + \\
5 & + & + \\
4 & + & + \\
3 & - & + \\
2 & - & + \\
1 & - & - \\
0.75 & - & + \\
\hline
\end{tabular}

では $1 \mathrm{mg} / \mathrm{d} l$ 迄検出する事が出来た.

以上の実験結果より，抗 alb 家鬼血清を希釈し，更に 抗家鬼 $\gamma$-glob を用いた DAE によって，通常の electrosyneresis では検出し得ない低濃度の抗原を検出する事が 出来るむのと考えられる. 抗家鬼 $\gamma$-glob 血清を希釈し ても DAE の感度は上昇しなかった事から，抗家鬼 $\gamma$ glob 血清の濃度は DAE の感度にあまり大きな影響は無 いむのと，我々は考えている。

本法は, 免疫沈降反応の感度を従来の方法より高める 事が出来る為に，今後その利用は $\alpha$-fetoprotein, $\mathrm{Au}$ - 抗 原等の臨床検査に迄広げる事が出来る. 更に我々は，本 法の抗原，抗体至適濃度比測定への応用についても検討 を加えている.

\section{2. $\alpha$-Fetoprotein $の$ radioimmuno- assay について}

$$
\begin{gathered}
\text { 西 信三・平井 秀松 } \\
(\text { 北大・医・第 } 1 \text { 生化学 })
\end{gathered}
$$

$\alpha$-Fetoprotein test はヘパトーマの鑑別診断法として 広く用いられつつある. $\alpha$-Fetoprotein $\left(\alpha_{\mathrm{f}}\right)$ の検出には 通常ゲル内沈降反応が用いられているがその検出限界は $10 \mu \mathrm{g} / \mathrm{ml}$ 附近である. 早期診断，陽性率の向上を期待 し 2 抗体法による radioimmunoassay による検出感度の 上昇を検討した (Table 1.).

${ }^{125} \mathrm{I}$ による精製 $\alpha_{\mathrm{f}}$ の標識は Chloramine T 法により 行なった. 標識 $\alpha_{\mathrm{f}}$ の比放射能は $16.6 \mu \mathrm{Ci} / \mu \mathrm{g}$ であった.

第 1 抗体としては家鬼抗 $\alpha_{\mathrm{f}}$ 血清, 第 2 抗体としては 山羊抗家鬼 IgG 血清を用いた。 
（100）生物物理化学

Table 1. Double antibody method.

$0.5 \%$ HoSA in $0.1 \mathrm{M}$ borate buffer, $\mathrm{pH} 8.6$

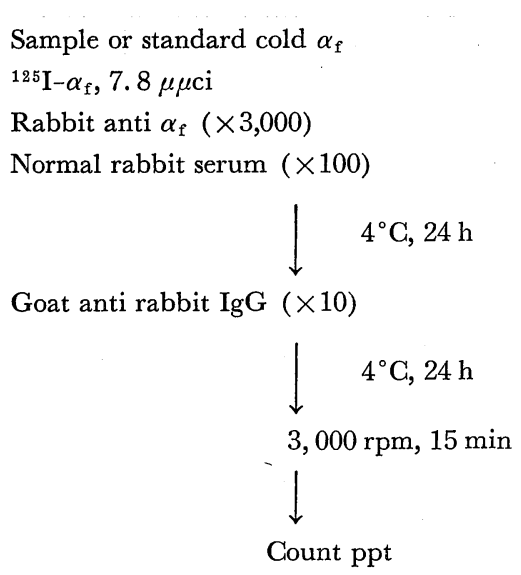

第 1 抗体の稀䣋は標識 $\alpha_{\mathrm{f}}$ を $40 \%$ 結合する 3,000 倍と した. 又第 2 反応のキャリャーとして正常家鬼血湇を加 えた。

第 1 反応，第 2 反応の時間はそれぞれ反応がプラトー に達している 24 時間とした.

非標識 $\alpha_{\mathrm{f}}$ による標識 $\alpha_{\mathrm{f}}$ の沈降阻害標準曲線を Fig. 1. に示す. $10 \mathrm{~m} \mu \mathrm{g} / \mathrm{ml}$ の $\alpha_{\mathrm{f}}$ む十分に検出可能であり約 1,000 倍の感度の上昇が見られた.

上記の方法により種々の血清の検討を行なった．健康 成人血清 10 例はいずれあが $10 \sim 20 \mathrm{~m} \mu \mathrm{g} / \mathrm{m} l$ という值が 得られたこれは $\alpha_{\mathrm{f}}$ を実際に含むためか，又は他の因 子によるのか検討を要しよう. ゲル内沈降反応で㓌性で あった原発性肝癌 29 例中 16 例が $50 \mathrm{~m} \mu \mathrm{g} / \mathrm{ml}$ 以上であ った. そのうち 8 例は $500 \mathrm{~m} \mu \mathrm{g} / \mathrm{ml}$ 以上であった.

細胆管癌は陰性であった.

他の疾患では肝炎 15/15(50 230 $\mathrm{m} \mu \mathrm{g} / \mathrm{ml})$, 肝硬変 $1 / 11(500 \mathrm{~m} \mu \mathrm{g}$ 以上), 5 力月以前の妊婦 $0 / 10,5$ 力月以 後の弤婦 $14 / 14(50-430 \mathrm{~m} \mu \mathrm{g} / \mathrm{m} l)$, 転移性肝癌 $3 / 11$, 他 の悪性腫瘍 $0 / 25$ であった.

転移性肝癌の陽性例は十分な組織学的検索を行なって おらずなお慎重な検討を要しよう. 肝炎における $\alpha_{\mathrm{f}}$ の 血中濃度は肝炎の病期, 病態像と何らかの関連を有する と想像される. またその血中濃度は比較的低くさらに多 数例の検索が必要ではあるがある一定值以上の症例は肝 炎でなくへパトーマとの診断も可能であろう.

組織学的にヘパトーマと確定している症例でなお $\alpha_{\mathrm{f}}$ 陰性例の存在することは Grabar らによるアフラトキシ ンで誘発したラットヘパトーマでは $\alpha_{\mathrm{f}}$ 陰性との報告す あり興味深し.

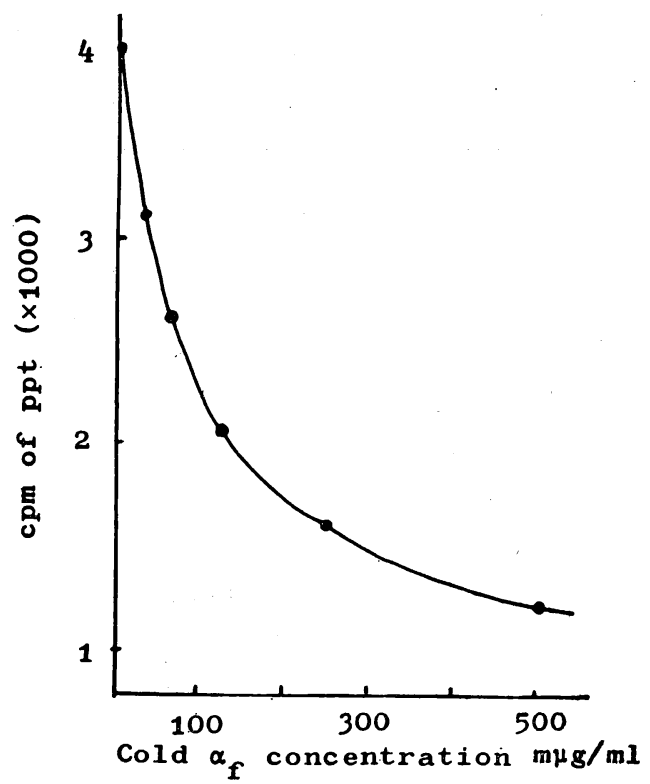

Fig. 1. Standard inhibition curve by cold $\alpha$-fetoprotein.

13. $\alpha_{1}$ 胎児蛋白検出方法の再検討 松田 重三・青木 紀生・河合 忠 (日大・医・臨床病理学)

$$
\text { 山岸 安子 - 大島毒美子 }
$$

（日大・中央検查科）

\section{後藤 利昭・大藤 紘一・金田 春雄 \\ (日大・医・第 3 内科)}

はじめに

1964 年 Tatarinov ${ }^{1)}$ によって臨床診断に導入されるよ うになった血清中の $\alpha_{1}$ 胎児蛋白（ $\alpha_{\mathrm{f}}$ と略す）を検出す る方法は, 原発性肝癌に最も特異性の高い診断法である ことが確認され ${ }^{2)}$ ，現在多くの研究者によって臨床診断 に応用されつつある.

しかし原発性肝癌と診断された症例のすべてに $\alpha_{\mathrm{f}}$ が 検出されているわけではない. 1970 年の平井 ${ }^{3)}$ の全国集 計によれば, 病理組織学的に原発性肝癌と診断された症 例の $78 \%$ に $\alpha_{\mathrm{f}}$ 陽性を示している.

明らかな原発性肝癌であるのに $\alpha_{\mathrm{f}}$ が検出されない理 由として，1 部の肝癌細胞で $\alpha_{\mathrm{f}}$ を産生していないとと あ考えられるが，一方では抗血清の力価とその検出方法 の感度に問題があるのかむしれない.

我々は後者の可能性を追求すべく検出方法の再検討を 行なった. しかすその方法は検査室で日常検査としても 十分に使用しうるあのであることを主目的にした. 


\section{1. 沈降反応を応用した種々の検查法の検討}

$\alpha_{\mathrm{f}}$ の検出方法としては従来我々が日常行なってきた 免疫電気泳動法, Ouchterlony 法に加え, immunoelectroendosmosis 法 (IEE 法), electroimmunodiffusion 法 (EID 法), single radial immunodiffusion 法 (SRD 法) および double-antibody radial diffusion 法 (DRD法)

各法について検討した.

$\alpha_{\mathrm{f}}$ に対する抗血清は自家製 (N), $\mathrm{M}$ 社製 $(\mathrm{M}), \mathrm{K}$ 社製 (K)の製品を使用した. また各検査法の鋭敏性の定量的 検討には精製した $\alpha_{\mathrm{f}}$ がないため， $\mathrm{H}$ 社製の prealb の 標準品とその抗血清を使用した.

Prealb を用いての検討結果を Table 1. に示した.

Table 1. The quantitative evaluation of various techniques, using the prealbumin-antiprealbumin system.

\begin{tabular}{|c|c|c|}
\hline Technique & Antisera & $\begin{array}{l}\text { Minimal antigen amount } \\
\text { demonstrated }(\mathrm{mg} / \mathrm{d} l)\end{array}$ \\
\hline I.E.P. & No dilution & $16 \times(1.687)$ \\
\hline Ouchterlony & $\begin{array}{l}\text { No dilution } \\
2 \times \text { dil. } \\
4 \times \text { dil }\end{array}$ & $\begin{array}{r}128 \times(0.2109) \\
128 \times(0.2109) \\
64 \times(0.4217)\end{array}$ \\
\hline I.E.E. & $\begin{array}{l}\text { No dilution } \\
2 \times \text { dil. } \\
4 \times \text { dil. }\end{array}$ & $\begin{array}{r}128 \times(0.2109) \\
128 \times(0.2109) \\
64 \times(0.4217)\end{array}$ \\
\hline S.R.D. & $\begin{array}{l}10 \times \text { dil } . \\
100 \times \text { dil } .\end{array}$ & $\begin{array}{l}128 \times(0.2109) \\
128 \times(0.2109)\end{array}$ \\
\hline D.A.D. & $\begin{array}{l}10 \times \text { dil } \\
100 \times \text { dil }\end{array}$ & $\begin{array}{l}256 \times(0.1055) \\
256 \times(0.1055)\end{array}$ \\
\hline E.I.D. & $10 \times$ dil & $256 \times(0.1055)$ \\
\hline
\end{tabular}

Ouchterlony 法に扣いての最少検出濃度は，抗血清を 原液のままおよび 2 倍希釈液，4 倍希釈液いずれを用い ても，抗原標準液の 64 倍希釈 $(0.4217 \mathrm{mg} / \mathrm{d} l$ に相当) であった.

IEE 法では抗血清を原液と 2 倍希釈液として使用した 場合, 抗原の 128 倍希釈 $(0.2109 \mathrm{mg} / \mathrm{d} l)$ まで検出可能 であり，4 倍希釈抗血清では抗原の 64 倍希釈 $(0.4217$ $\mathrm{mg} / \mathrm{d} l)$ と感度がやや低くなった.

EID 法では 10 倍希釈抗体寒天ゲルを用い抗原の 256 倍希釈 $(0.1055 \mathrm{mg} / \mathrm{d} l)$ まで検出可能であった.

10 倍希釈抗体寒天ゲルを用いた SRD 法では抗原の 128 倍希釈 $(0.2109 \mathrm{mg} / \mathrm{d} l)$ が最少検出濃度であり, 100 倍希釈抗体寒天ゲルを用いても同様の成績であった。

$\mathrm{SRD}$ 法を実施後, 螢光抗体法のいわゆるサンドウィ
ッチ法と同原理のあとに，さらに抗体を添加する DRD 法では，その感度は SDR 法よりも高く, 10 希橎抗体寒 天ゲルを用いて抗原の 526 倍希釈 $(0.1055 \mathrm{mg} / \mathrm{d} l)$ まで 検出された. 100 倍希釈抗体寒天ゲルを使用しても同様 の成績であった。

免疫電気泳動法に执いては，抗原の 16 倍希釈 (1.687 $\mathrm{mg} / \mathrm{d} l)$ まで検出されるにすぎなかった.

EID 法, SRD 法, DRD 法は多量の抗血清を必要と し,また抗原性の確認に問題点があるが, 定量的な成績が えられる利点がある. IEE 法では抗血清が少量ですみ， しかも短時間で検出可能であるが，定量および同定には むかない. Ouchterlony 法および免疫電気泳動法は感度 が低い難点はあるものの同定には不可欠な方法である.

以上の検索結果怙よび各方法の特長から，スクリー二 ングとしては IEE 法が，同定には Ouchterlony 法, 定 量には SRD または DRD 法が最適と考えられた.

最近 $\mathrm{Kohn}^{4)}$ が IEE 法の鋭敏性, 迅速性にさらに同定 の操作を加えた方法を発表した. 陰極側に 2 つの穴をつ くり, 一方には既知抗原を他方には末知抗原を入れ, 対 側の陽極に抗血清の穴をつくり泳動すると，既知抗原之 同じ抗原性をもつ場合 identityをもった沈降線が出現し スクリーニングと同定を同時に行なえる方法である.

\section{2. 種々の検出法を用いた場合の $\boldsymbol{a}$ - 胎児蛋白陽性率 の検討}

前項の成績を参考に各症例について $\alpha_{\mathrm{f}}$ の有無を再検 討した. その結果を Table 2., Table 3. に示す.

症例は原発性肝癌 22 例 25 検体, 肝硬変症 20 例 36 検 体, 慢性肝炎 18 例, 覀急性肝炎 3 例 4 検体, 急性肝炎 1 例，乳巟肝炎 8 例，胆管癌 3 例 5 検体，胆石症 2 例， 肝転移例を含む胃癌 4 例, 悪性腫瘍 6 例, その他 3 例の 計 112 例を使用し，同時に各月別妊婦血清 60 例につい ても $\alpha_{\mathrm{f}}$ の有無を検討した.

以前において $\alpha_{\mathrm{f}}$ 陽性であった明らかな原発性肝癌 16 例には, IEE 法にて全例沈降線を認め, 各種疾患中あら たに沈降線を認めたのは 15 例であった.そのうちわけ は原発性肝癌 4 例 6 検体, 肝硬変症 1 例 2 検体, 要急性 肝炎 2 例 3 検体, 乳児肝炎 4 例である.

各月別妊婦血清においては全例沈降線を認めなかった (Table 4.).

これら症例の沈降線を同定するためOuchterlony 法に て検索したとてろ，6 例に扎いて既知 $\alpha_{\mathrm{f}}$ 抗原と pattern of complete identity を示した. これら症例のうち検体 不足のため検討出来なかった 1 例をのぞき他の 5 例では， EID 法, SRD 法において沈降帯の出現をみた. しかし 免疫電気泳動法においては 1 例にのみ $\alpha_{1}$ 分画に沈降線 を認めたにすぎなかった。 
Table 2. Positivity of $\alpha$-fetoprotein in various clinical conditions.

\begin{tabular}{l|c|c|c|c}
\hline \multicolumn{1}{c|}{ Diseases } & Cases & Numbers examined & $\alpha_{\mathrm{f}}$-positive & $\alpha_{\mathrm{f}}$-negative \\
\hline Hepatoma & $22(2)$ & 25 & $20(2)$ & 5 \\
Cholangiocarcinoma & 3 & 5 & 0 & 5 \\
Liver cirrhosis & $20(8)$ & 36 & 0 & 36 \\
Chronic hepatitis & 18 & 18 & 0 & 18 \\
Sub-acute hepatitis & 3 & 4 & $1(1)$ & 3 \\
Acute hepatitis & 1 & 1 & 0 & 1 \\
Cholelithiasis & 2 & 2 & 0 & 2 \\
Gastric cancer (including & 4 & 4 & 0 & 4 \\
metastasis to liver) & 6 & 6 & 0 & 6 \\
Other malignant tumors & $8(8)$ & 8 & 0 & 8 \\
Infantile hepatitis & 60 & 60 & 0 & 60 \\
Pregnancy . & $3(3)$ & 3 & 0 & 3 \\
Miscellaneous & 150 & 172 & 21 & 151 \\
\hline \multicolumn{1}{c}{ Total } & & & 0 \\
\hline
\end{tabular}

( ) Not confirmed pathologically.

Table 3. The results for detection of $\alpha$-fetoprotein using various techniques.

\begin{tabular}{|c|c|c|c|c|c|c|c|c|c|c|c|c|c|c|c|c|}
\hline Patients & & U.S. & U.S. & I. T. & I. T. & O.Y. & S.S. & K. R. & A. K. & I. G. & M.F. & M.F. & M.F. & H. Y. & U.T. & K. T. \\
\hline Date & & $4 / 10$ & $12 / 10$ & $23 / 10$ & $2 / 2$ & & & & & & $1 / 4$ & $27 / 5$ & $9 / 11$ & & & \\
\hline Diagnosis & & $\begin{array}{l}\text { Ahr. } \\
\text { epa- } \\
\text { itis }\end{array}$ & $\begin{array}{l}\text { Chr. } \\
\text { hepa- } \\
\text { titis }\end{array}$ & $\begin{array}{l}\text { Liver } \\
\text { cir- } \\
\text { rhosis }\end{array}$ & $\begin{array}{l}\text { Liver } \\
\text { cir- } \\
\text { rosis }\end{array}$ & $\begin{array}{l}\text { Inf. } \\
\text { hepa- } \\
\text { titis }\end{array}$ & $\begin{array}{l}\text { Inf. } \\
\text { hepa- } \\
\text { titis }\end{array}$ & $\begin{array}{l}\text { Inf. } \\
\text { hepa- } \\
\text { titis }\end{array}$ & $\begin{array}{l}\text { Inf. } \\
\text { hepa- } \\
\text { titis }\end{array}$ & $\begin{array}{l}\text { Hepa- } \\
\text { toma }\end{array}$ & $\begin{array}{l}\text { Hepa- } \\
\text { toma }\end{array}$ & $\begin{array}{l}\text { Hepa- } \\
\text { toma }\end{array}$ & $\begin{array}{l}\text { Hepa- } \\
\text { toma }\end{array}$ & $\begin{array}{l}\text { Hepa- } \\
\text { toma }\end{array}$ & \begin{tabular}{|l|} 
Hepa- \\
toma
\end{tabular} & $\begin{array}{l}\text { Sub- } \\
\text { acute } \\
\text { hepa- } \\
\text { titis }\end{array}$ \\
\hline I.E.E. & $\begin{array}{l}\mathrm{M} \\
\mathrm{K} \\
\mathrm{N}\end{array}$ & $\begin{array}{l}+ \\
+\end{array}$ & $\begin{array}{l}+ \\
+ \\
+\end{array}$ & $\begin{array}{l}+ \\
+\end{array}$ & $\begin{array}{l}+ \\
+\end{array}$ & + & + & $\begin{array}{l}+ \\
+\end{array}$ & + & $\begin{array}{l}+ \\
y\end{array}$ & $\begin{array}{l}+ \\
+ \\
+\end{array}$ & $\begin{array}{l}+ \\
+ \\
+\end{array}$ & + & $\begin{array}{l}+ \\
+ \\
+\end{array}$ & $\begin{array}{l}+ \\
+ \\
+\end{array}$ & $\begin{array}{l}+ \\
+\end{array}$ \\
\hline E.I.D. & $\mathbf{M}$ & + & + & & & & & & & I & + & + & & + & + & \\
\hline S.R.D. & $\mathbf{K}$ & + & + & & & & & & & $\nearrow$ & + & + & & + & + & \\
\hline Ouchter. & $\mid \begin{array}{l}\mathrm{M} \\
\mathrm{K} \\
\mathrm{N}\end{array}$ & + & & & & & & & & + & $\begin{array}{l}+ \\
+\end{array}$ & + & & + & $\begin{array}{l}+ \\
+\end{array}$ & \\
\hline I.E.P. & N & & & & & & & & & & + & & & & & \\
\hline
\end{tabular}

$\mathrm{M}, \mathrm{K}, \mathrm{N}$ : antisera preparations, see text.

IEE 法で沈降線が出現したが, Ouchterlony 法にて $\alpha_{\mathrm{f}}$ であることを否定されたのは 10 例である.このうち臨 床的に亜急性肝炎と診断された U.S. 例は，最後は激烈 な経過で死亡したが，剖検が出来ず最終的に needle necropsy にて病理学的確認がなされた. その経過中に採取 した 2 検体のうち 10 月 9 日の血清中には $\alpha_{\mathrm{f}}$ が存在する ことを確認したが， 3 日後の血清においては IEE 法, EID 法，SRD 法に打いて沈降線（帯）の出現をみたが，
Ouchterlony 法にて $\alpha_{\mathrm{f}}$ は確認できなかった.

$\alpha_{\mathrm{f}}$ と同定された 6 症例のうち 4 例について $\mathrm{Kohn}^{4)}$ の 方法によって IEE 法を行なったとてろ沈降線の出現と ともに, 既知 $\alpha_{\mathrm{f}}$ 抗原の沈降線と瘾合した (Fig. 1.).

$\alpha_{\mathrm{f}}$ と同定された 6 例のうちわけは，原発性肝癌 5 例 (うち 2 例は同一症例), 亜急性肝炎 1 例であるが, 後者 は剖検によらず needle necropsy にて病理組織学的確認 がなされている。 
Table 4. The results for detection of $\alpha$-fetoprotein in pregnancy.

\begin{tabular}{c|r|c|c}
\hline \hline Gestation (mo.) & cases & $\alpha_{\mathrm{f}}$-positive & $\alpha_{\mathrm{f}}$-negative \\
\hline 2 & 1 & 0 & 1 \\
3 & 5 & 0 & 5 \\
4 & 7 & 0 & 7 \\
5 & 3 & 0 & 3 \\
6 & 4 & 0 & 4 \\
7 & 8 & 0 & 8 \\
8 & 14 & 0 & 14 \\
9 & 10 & 0 & 10 \\
10 & 8 & 0 & 8 \\
\hline Total & 60 & 0 & 60 \\
\hline
\end{tabular}

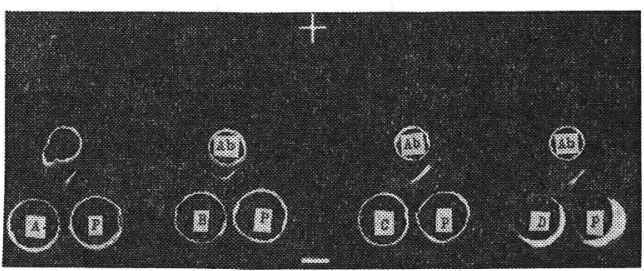

Fig. 1. Precipitation patterns obtained by Kohn's immunoelectroendosmotic technique.

$\mathrm{Ab}:$ Anti- $\alpha_{\mathrm{f}}$ serum.

A, B, C, and D : Patient's sera.

$\mathrm{P}: \alpha_{\mathrm{f}}$-positive control.

我々は現在までに病理組織学的に原発性肝癌と診断さ れた21例 25 検体について $\alpha_{\mathrm{f}}$ の検索を行ない, 症例の $76 \%$ において $\alpha_{\mathrm{f}}$ が検出されたのであったが，今回の再 梌索により 21 例中 19 例飞 $\alpha_{\mathrm{f}}$ が検出され，その陽性率 は $91 \%$ となった (Table 5.).

Table 5. The results for detection of $\alpha$-fetoprotein in hepatoma.

\begin{tabular}{l|c|c|c|c}
\hline & Cases & $\alpha_{\mathrm{f}}$-positive & $\alpha_{\mathrm{f}}$-negative & \\
\hline Previous series & $22(2)$ & $16(2)$ & 5 & $76 \%$ \\
Present series & $22(2)$ & $20(2)$ & 2 & $91 \%$ \\
\hline
\end{tabular}

( ) Not confirmed pathologically

そのうち 1 例（A.S. 例）においては，その経過中 $\alpha_{\mathrm{f}}$ 陰性の時期から陽性へ転化したととを認めた. との症例 は現在入院中で病理組織学的検索は行なわれていないが, 触診所見, 肝シンチグラムその他から肝硬変症をともな った原発性肝癌であるととは, 間違いないものと思われ る. また他の 1 例 (M.F. 例) においては，原発性肝癌 と診断され左葉切除をうけたが，術前陽性であった $\alpha_{\mathrm{f}}$
はその後除性となり，現在外来通院中である.<smiles>[111In]</smiles>

我々は prealb を使用して各種検出法に拈ける鋭敏度 の検討を行ない，その結果を参考に各種疾患 112 例を対 象に $\alpha_{1}$ 胎児蛋白 $\left(\alpha_{\mathrm{f}}\right)$ の有無の再度検討を試みた．同時 に妊婦血清 60 例についても $\alpha_{\mathrm{f}}$ の有無を調べた.

Prealb を使用しての検討では electroimmunodiffusion 法 (EID 法), double-antibody radial diffusion 法 (DRD 法) が鋭敏で， immunoelectroendosmosis 法 (IEE 法), single radial immunodiffusion 法 (SRD 法) がこれにつ ぎ, Ouchterlony 法, 免疫電気泳動法の順に感度が低い ことがわかった。

これら各検出法における感度, 検出に要する時間, 抗 血清使用量, 定量性ならびに同定の可能性などを総合し た結果，スクリーニングには IEE 法, 同定には Ouchterlony 法, 定量には DRD 法または SRD 法が最適と思わ れた。

これらの成績を参考に $\alpha_{\mathrm{f}}$ の再スクリーニングを行な ったところ，IEE 法にて各種疾患 112 例中あらたに 15 例に沈降線の出現をみた. てれらをOuchterlony 法にて 確認したところ 6 例が $\alpha_{\mathrm{f}}$ であることを同定しえた. こ のうち 5 例（2 例は同一症例）が原発性肝癌で，4 例は 病理組織学的飞確認されている. 他の 1 例は亜急性肝炎 例で, needle necropsy にて確認された.

これら 6 例のうち 4 例を Kohn の IEE 法にて検索し たところ，定性とともに同定が可能であるととを確認し た. 今後利用されてよい方法と思われる.

同時に検索した 60 例の妊婦血清では全例 $\alpha_{\mathrm{f}}$ は検出さ れなかった。

以上の検索結果より, 明らかな原発性肝癌において従 来の Ouchterlony 法, 免疫電気泳動法に加えて, より 鋭敏な検出方法を用いるととにより $\alpha_{\mathrm{f}}$ の検出率が，明 らかに增加することが確認された．しかむなおスクリー ニングの段階に扰いて原発性肝癌以外の症例に沈降線の 出現をみたととから，純粋な mono-specific な抗血清が 必要であることはあちろんであるが，検出方法の工夫に よりさらに $\alpha_{\mathrm{f}}$ の診断的意義を増加させることができよ う.

$$
\text { 文献 }
$$

1) Tatarinov, Yu.S.: Vop. Med. Khim., 11, 90 (1964).

2) Uriel, J. et al.: Presse Med., 76, 1415 (1968).

3) 平井秀松 : 臨床検査, 14, 1061 (1970).

4) Kohn, J.: Clin. Pathol., 23, 733 (1970). 


\section{4. $a$-Fetoprotein 検出法についての検討}

$\begin{array}{llll}\text { 西岡 幹夫・沖田 極 - 児玉 } & \text { 隆浩 } \\ \text { 岡本 佳千・宮里 } & \text { 薫・藤田 } & \text { 輝雄 }\end{array}$

（山口大 $\cdot$ 医 $\cdot$ 第 1 内科）

\section{弘長 恭三 \\ (同上・薬郕部)}

目的

$\alpha$-fetoprotein (以後 $\alpha_{\mathrm{f}}$ と略す） の検出感度の下限は $1 \mathrm{mg} / \mathrm{d} l$ 前後であるが ${ }^{1,2)} ， 乙 の$ 倹出感度を更に上げる こと，並びにすぐれた $\alpha_{\mathrm{f}}$ 特異抗血清を作製するととは 肝癌の早期発見を可能にするすのと思われる. 今回は, 各種感作抗原により, 抗血清を作製し, 各種 $\alpha_{\mathrm{f}}$ 検出法 を比較検討し，若干の知見を得たので報告する.

\section{研究材料及び方法}

1) 抗血清: $\alpha$-fetoprotein $\left(\alpha_{\mathrm{f}}\right)$ に対する抗体は次の 各種抗原を感作抗原として家鬼を免疫し作製したもので ある.

(1)調製ディスク電気泳動法により精製された胎児 $\alpha_{\mathrm{f}}$ $\left(\alpha_{\mathrm{f}}\right)$ ，(2)肝細胞癌患者血清の Sephadex G 200 によるゲ ル汇過分画液 (S 20)，(3)同上患者血清の $34 \%$ 飽和硫安 カットにより得た分画液 (H.B)，(4) 肝癌組織抽出液の $50 \%$ 飽和硫安カット上清液 (H.S), (5)患者腹水 (A.S), (6)患者全血清（W.S）などである. 抗血清の力洒はほぼ 一定にした.

2） $\alpha_{\mathrm{f}}$ の検出法 : $\alpha_{\mathrm{f}}$ の検出は Ouchterlony 法, 抗体 寒天平板法 (SRID) ${ }^{2)}$, immunoelectrosyneresis (IES), 螢 光電気免疫拡散法 $(\text { FIES })^{3,4)}$ などを用いて行なった.

3）検体並びに $\alpha_{\mathrm{f}}$ の基準液：検体は組織学的に原発 性肝癌と確診された 20 症例の患者血清で, 対照として その他の肝疾患を選んだ. 急性肝炎 18 例, 慢性肝炎 21 例, 肝硬変症 31 例である. $\alpha_{\mathrm{f}}$ の基準液は $\alpha_{\mathrm{f}}$ の最高濃 度を有する患者血清を用い, その濃度はディスク電気泳 動像から $428 \mathrm{mg} / \mathrm{d} l$ と算定されたあのである ${ }^{5)}$.

\section{研 究 成 績}

$\alpha_{\mathrm{f}}$ 検出法の感度： $\alpha_{\mathrm{f}}$ の基準液を原血清加 16,384 倍まで倍数希釈したあのにつき, 抗 H.B 血清を用いて各 種 $\alpha_{\mathrm{f}}$ 検出法によりその検出感度を此較した結果，FIES が極めてすぐれていることがわかる (Table 1.).

各種抗血清による $\alpha_{\mathrm{f}}$ の検出感度の差を IES により $\alpha_{\mathrm{f}}$ 基準液について検討したが，抗血清による $\alpha_{\mathrm{f}}$ 検出感度 の大差は認めなかったが，高濃度 $\alpha_{\text {f }}$ の検出は抗 W.S 血
Table 1. Comparison of various Methods for Detection of $\alpha_{\mathrm{f}}$.

\begin{tabular}{|c|c|c|c|c|c|c|}
\hline \multicolumn{2}{|c|}{ Serum } & \multicolumn{5}{|c|}{ Method for detection of $\alpha_{\mathrm{f}}$} \\
\hline \multirow{2}{*}{ Concent. } & \multirow{2}{*}{$\begin{array}{l}\text { Levels of } \\
\alpha_{\mathrm{f}}\end{array}$} & \multirow{2}{*}{$\begin{array}{l}\text { Ou- } \\
\text { chter. }\end{array}$} & \multicolumn{2}{|c|}{ SRID } & \multirow{2}{*}{ IES } & \multirow{2}{*}{ FIES } \\
\hline & & & High & Low & & \\
\hline $1 \times$ & $428 \mathrm{mg} / \mathrm{d} l$ & + & + & - & + & + \\
\hline $2 \times$ & 214 & + & + & - & + & + \\
\hline $4 \times$ & 107 & + & + & - & + & + \\
\hline $8 \times$ & 53.5 & + & + & - & + & + \\
\hline $16 \times$ & 26.8 & + & + & + & + & + \\
\hline $32 \times$ & 13.4 & + & + & + & + & + \\
\hline $64 \times$ & 6.7 & + & + & + & + & + \\
\hline $128 \times$ & 3.3 & + & - & + & + & + \\
\hline $256 \times$ & 1.7 & + & - & + & + & + \\
\hline $512 \times$ & 0.8 & - & - & + & + & + \\
\hline $1,024 \times$ & 0.4 & - & - & \pm & + & + \\
\hline $2,048 \times$ & 0.2 & - & - & - & \pm & + \\
\hline $4,096 \times$ & 0.1 & - & - & - & - & + \\
\hline $8,192 \times$ & 0.05 & - & - & - & - & \pm \\
\hline $16,384 \times$ & 0.03 & - & - & - & - & - \\
\hline
\end{tabular}

清が劣った。

低濃度の, 又, Ouchterlony 法では $\alpha_{\mathrm{f}}$ を検出できな い 7 症例を選び，各種抗血清を用いて $\alpha_{\mathrm{f}}$ の検出を行な った所，抗血清の差により $\alpha_{\mathrm{f}}$ の検出率は異なる (Table 2.). 乙れは抗血清の感作抗原の差に起因すると思われる. 原発性肝細胞癌 20 症例につき各種抗血清, 検出法に て血清中の $\alpha_{\mathrm{r}}$ の検出を行なうと全例に $\alpha_{\mathrm{f}}$ が検出された. 急性肝炎, 慢性肝炎の 39 症例では $\alpha_{\mathrm{f}}$ 認められず，腅硬 変症の 31 例中 1 例に FIES のみで $\alpha_{\mathrm{f}}$ が検出された. 以 上の成績から，FIES は $\alpha_{\mathrm{f}}$ 検出にもすぐれた方法であり，

Table 2. Results of precipitin tests for detection of $\alpha_{\mathrm{f}}$ using various antisera.

\begin{tabular}{l|c|c|c}
\hline \multicolumn{1}{r|}{ Methods } & Ouchter. & IES & FIES \\
Antiserum & & & \\
\hline Anti- $\alpha_{\text {f }}$ (Fetus) & $2 / 7$ & $3 / 7$ & $5 / 7$ \\
S 20 (H.F) & $2 / 7$ & $3 / 7$ & $5 / 7$ \\
HB(H.F) & $2 / 7$ & $3 / 7$ & $7 / 7$ \\
HS(H.F) & $2 / 7$ & $2 / 7$ & $7 / 7$ \\
AS(Y.N) & $3 / 7$ & $4 / 7$ & $6 / 7$ \\
WS(U.O) & $2 / 7$ & $6 / 7$ & $7 / 7$ \\
\hline
\end{tabular}

肝癌の早期発見の可能性を示すむのであり，又，原発性 肝細胞癌における $\alpha_{\mathrm{f}}$ の検出率は従来の報告より高率で 
あると思われる。

$$
\text { ま とめ }
$$

$\alpha_{\mathrm{f}}$ の検出感度は FIES, IES, SRID, Ouchterlony 法の 順にすぐれ，FIES は $0.05 \mathrm{mg} / \mathrm{d} l$ 前後まで $\alpha_{\mathrm{f}}$ を検出で きる。

感作抗原の差により, 抗血清の $\alpha_{\mathrm{f}}$ 検出率に若干の差 がある.

\section{文献}

1) 平井秀松 : 熟療, 23,2190 (1970).

2) 藤田輝雄他 : 新薬と臨床, 20,511(1971).

3) 松橋 直: 医学のあゆみ，73,169(1970).

4) 西閐幹夫他：医学のあ收み，投稿中.

5)西岡幹夫他 : Clin. Chim. Acta. 31, 439 (1971).

\section{5. 数種の動物の $a$-fetoprotein の免疫 学的交叉反応について}

\section{西信三・渡部 博之・平并 秀松 \\ (北大・医・第 1 生化学)}

昨年の本学会に扔いて我々は人扰よびラットに関して， 胎児性蛋白の 1 つである $\alpha$-fetoprotein $\left(\alpha_{\mathrm{f}}\right)$ と肝癌の関 係および精製とその性質について報告した. 今回，更に 他の動物における $\alpha_{\mathrm{f}}$ の存在及び免疫化学的な性質を検 討したので報告する.

D. Gitlin は 1967 年に，人及びラットの $\alpha_{\mathrm{f}}$ に対する 抗血清 (鬼) を用いて, 各種動物の $\alpha_{\mathrm{f}}$ との交叉反応を 兒ているが, 抗人 $\alpha_{\mathrm{f}}$ は他の動物（猿, 犬, 猫, 羊, ア ザラシ，アルマジロ）と反応するが，抗ラット $\alpha_{\mathrm{f}}$ は人 及び他の動物とは反応しないと報告している.

そこで我々は，抗人 $\alpha_{\mathrm{f}}$ と抗ラット $\alpha_{\mathrm{f}}$ の家鬼血清及び 馬血清の栭者を用いて検討し，次の如き結果をえた.

(Table 1.)

Table 1

\begin{tabular}{l|c|c||c|c}
\hline $\begin{array}{l}\text { anti- } \\
\alpha_{\mathrm{f}}\end{array}$ & $\begin{array}{c}\text { Anti } \\
\text { human } \alpha_{\mathrm{f}} \\
\text { (rabbit) }\end{array}$ & $\begin{array}{c}\text { Anti } \\
\text { human } \alpha_{\mathrm{f}} \\
\text { (horse) }\end{array}$ & $\begin{array}{c}\text { Anti rat } \\
\alpha_{\mathrm{f}} \\
\text { (rabbit) }\end{array}$ & $\begin{array}{c}\text { Anti rat } \\
\alpha_{\mathrm{f}} \\
\text { (horse) }\end{array}$ \\
\hline human & Htt & Ht & - & + \\
rat & - & + & $+t$ & $+H t$ \\
dog & $+t$ & $+t$ & - & - \\
cat & $+t$ & $+t$ & - & - \\
rabbit & - & + & - & - \\
bovine & - & \pm & - & - \\
\hline
\end{tabular}

交叉反応の程度は抗血清の種類により著差があり，抗
人 $\alpha_{\mathrm{f}}$ 馬抗血清が最もよく交叉反応を示した. 又，各動 物間では犬，猫は fuse する沈降線を形成し他はいずれ む spur を形成した。

2. 免疫電気泳動法により各 $\alpha_{\mathrm{f}}$ の易動度を調査した ところ，人の $\alpha_{\mathrm{f}}$ が一番速く alb と $\alpha_{1}$-glob の間にくる が，他は人のむのより遅くそれぞれの血清の $\alpha_{1}$ から $\beta$ 領域に広く分布した。

以上の結果に加え，交叉反応を利用し抗人 $\alpha_{\mathrm{f}}$ (馬) を用いて $2 ， 3$ の動物から $\alpha_{\mathrm{f}}$ を免疫化学的方法で精製分 離し，その物理化学的性状を人及びラットのものと此較 検討の予定である.

な衫誹細な内容は本号 79-82 頁に原著として揭戴し た.

\section{6. ポリマー型 $\operatorname{IgA}$ 骨髄腫}

\section{伊藤 宜則・佐々木 實 \\ (名古屋市立大・医・生化学)}

IgA 骨髄腫は程度の異なったいろいろな段階のポリマ 一を形成するととがあるが，我々は単一なポリマーだけ が存在し，原型であるモノマーがほとんどみられないよ うな,いわゆる polymer type IgA myeloma 䒚経験した。 IgA 骨髄腫の症例により，乙の様な分子の会合に程度の 差がみられるととは，分子の基本構造にあそれに相当す るだけの差異があるものと考えられる．今回はこれに関 する検討の 1 回目として, 粘度の測定之各種条件下での 超遠心像扰よび単離 IgA 蛋白の型決定を行なったので 報告する。

\section{実 験 結 果}

患者血清のセルロースアセテート電気泳動像は $\gamma_{1}$ 領 域に pseudo-wavy band の形成がみられ, densitogram による測定では alb 30 40\% で腫場蛋白質が 40 50\% を占める. また, 免疫電気泳動像でも同じく $\gamma_{1}$ 領域に 著明に增加した沈降線がみられ，乙れは対照位におかれ た抗 IgA 血清との間に生じた沈降線と一致する.一般 亿骨髄腫血清の粘度は高いが，乙の血清の粘度はとりわ け著しく高く, 低温 $\left(4^{\circ} \mathrm{C}\right)$ では水飴状 (但し cryoglobulinemia にみられる様なゲル化は拉てらない) を呈す る. $20^{\circ} \mathrm{C}$ に㧊ける比粘度は Table 1. 亿示す如く正常血 清の約 4 倍である. この粘度は血清に DTT (dithiothreitol）を加えることにより下り，0.02M で最低值とな る.

0.02 M Phosphate buffer, $\mathrm{pH}$ 7. 0, 0.2 M NaCl 溶液て 8 倍に希橎したこの血清の超遠心像は，Fig. 1. の如く 
Table 1. Viscosity of IgA myeloma serum.

$\frac{\eta_{\mathrm{sp}} \text { of } 10 \% \text { myeloma serum }}{\eta_{\mathrm{sp}} \text { of } 10 \% \text { normal serum }}=\frac{0.1548}{0.0390}=4.0$

Time $\eta_{\mathrm{sp}}$

5\% Myel. serum 483.7 sec 0.0773 in $0.01 \mathrm{M}$ DTT $478.8 \quad 0.0664$ in $0.02 \mathrm{M}$ DTT $476.5 \quad 0.0613$ in $0.04 \mathrm{M}$ DTT $479.5 \quad 0.0679$

at $20^{\circ} \mathrm{C}$

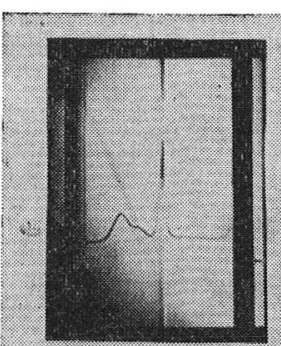

Without DTT

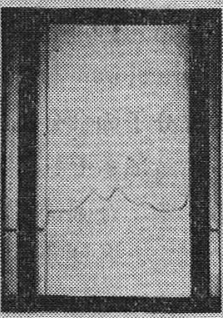

DTT $001 \mathrm{M}$

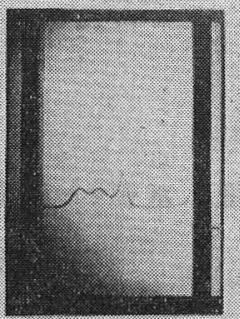

DTt $0.005 \mathrm{M}$

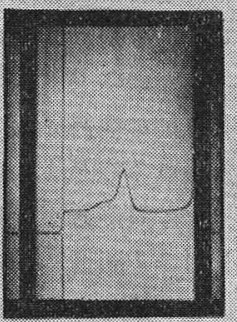

DT $1002 \mathrm{M}$
Fig. 1. Ultracentrifugal patterns of $\operatorname{IgA}$ myeloma serum with and without reducing reagent (DTT). 55,000 rpm., 8 times dilution with $0.02 \mathrm{M}$ phosphate buffer at pH 7.0, with $0.2 \mathrm{M} \mathrm{NaCl}$. Patterns were taken 65 minutes after reaching maximum speed at $20^{\circ} \mathrm{C}$.

$11 \mathrm{~S}$ 附近に尖鋭なピークが現われ，4.5S 成分に比して $7 \mathrm{~S}$ 成分の増加はみられない. これに DTT を加えてゆ くと, $11 \mathrm{~S}$ 成分は徐々に $7 \mathrm{~S}$ に移行し，0.02M でほぼ 完全に $11 \mathrm{~S}$ 成分は消失した. この結果は比粘度測定で, その最低值が DTT $0.02 \mathrm{M}$ であったこととよく一致す る.とのととから，高い粘性を示す原因は腫瘍蛋白質の 会合によるものと思われる.

患者血清の総蛋白濃度は治療前 $13 \mathrm{~g} / \mathrm{d} l$ であったもの が, 治療経過と共に $8.0 \mathrm{~g} / \mathrm{d} l$ に減少してきたが, その 時点においても $11 \mathrm{~S}$ 成分の単一性には変化がなかった. また，酸性（pH 3.5）扣よび変性剂 (6M urea) 存在下
でも $11 \mathrm{~S}$ 成分が他の成分に移行する現象はほとんど認 められなかったが，アルカリ性（pH 10.0）溶媒中では $11 \mathrm{~S}$ 成分は消失して $4.5 \mathrm{~S}$ と $7 \mathrm{~S}$ 成分に移行した像を示 した.

次に，この会合腫瘍蛋白質が均一であり酸，変性剂に 刘しても安定であることから, polymer 形成には乳汁や 唾液中の IgA の如く, secretory piece の介在も考えら れた. しかし，抗 secretory piece 血清との反応では沈降 線の形成はみられなかった。

腫痬 IgA 蛋白質は Sephadex G-200 によるゲル沪過, DEAE cellulose を用いる gradient elution chromatography, starch block 電気泳動等により精製されたが，その 過程と免疫電気泳動による分析結果は Fig. 2. の様であ

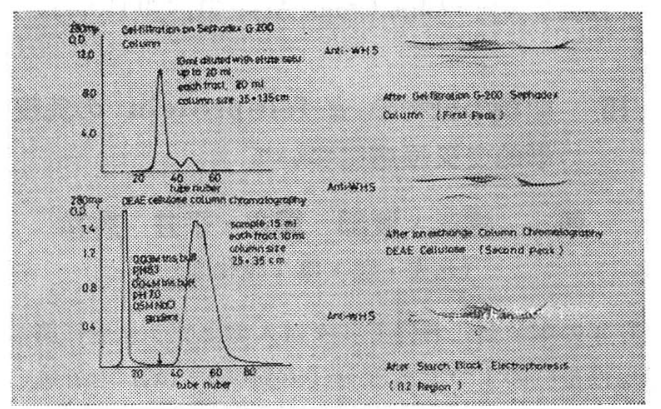

Fig. 2. Isolation process of polymer-type IgA myeloma protein.

る. 最初の G-200 によるゲル汇過で腫瘍蛋白質は第 1 ピークに溶出され, 分子量 30 万以上の $\alpha_{2}$-macro., $\beta$-Lp, $\operatorname{IgM}$ などの成分が混在している. 次にこの第 1 ピーク を DEAE cellulose で分離すると，腫瘍蛋白成分は第 2 ピークに溶出され混在成分は減少するが，なお $\beta-\mathrm{Lp}$ が 少量共存する.とれを starch block 電気泳動で分離し均 一な IgA がえられた.精製 IgA は Fig. 3.の如く, anti-

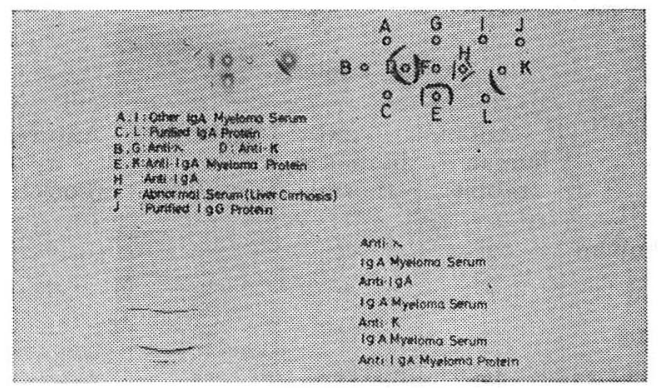

Fig. 3. Type determination of IgA myeloma protein.

とは反応せず，anti- $\kappa$ との間に沈降線を生ずる. 一方，

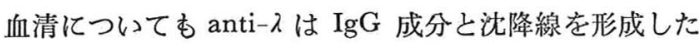


が IgA 成分とは沈降線を示さなかった。 anti- $\kappa$ は IgG 成分之 IgA 成分共に沈降線を示し, IgA の增殖部む沈 降線を形成した.

これらの結果から，との IgA 骨㖪腫蛋白質は $\kappa$ 型に 属し，そのほとんどが均一な会合体を形成している，そ の会合体は酸や変性剤によっても比較的安定であり, 分 泌型 IgA にみられるような secretory piece は共有して いない。しかしながら，アルカリや還元試菂の存在下で は解離が起り, 著しく高い粘性はそれと共に減少すると とが示された。

（本症例の御紹介を睗わった名市大中検牧野先生之貴 重な抗 secretory piece 血清を快く御送付頂きました北大 第 1 生化学教室の平井先生，小林先生に深謝致します.)

\section{7. 馬血清免疫グロブリンの母子間移行}

\section{牧村進・友田勇・臼并和哉 (菒大・農・家畜内科)}

正常馬血清蛋白分画値に関しては, Tiselius 法, 汇緍法 またはセルロースアセテート法等による報告はあるが， いずれも当才以上の馬についての報告であり，特に育成 馬の血清免疫 glob（以下 Ig 之略す）についての詳細な 報告はみあたらない，そこで我々は臨床応用面への基䃈 的資料を得るため，馬血清 $\operatorname{Ig}$ の是子間移行执よび青成 過程に拈ける動態を single radial immunodiffusion 扰よ び免疫電気泳動法を用いて検討した。

\section{実 験 材 料}

牝馬 2 頭（4 オアングロアラブ， 14 才準サラブレッ ド）からの新生子 2 頭について, 分婏時臍带血清, 初乳 摄取後定時間ごとの新生子血清扝よび生後 6 カ月までの 子馬血清を採取した. 乳は分婏直後抒よびその後の洔期 に採取し, 乳清を分離した.さらに 7 カ月令 2 才の育 成馬扰よび 4 才 27 才の繁殖牝馬の血清を採取した.

\section{实 験 方 法}

Single radial immunodiffusion は Fahey らの方法に準 じて行なった.すすなお $8.5 \times 11 \mathrm{~cm}$ のガラス板上に厚 さ $1 \mathrm{~mm}$ の特異抗血清含有寒天平板を作り, 陚料孔に 既知濃度の各 Ig の段階稀釈液, または適度に稀釈した

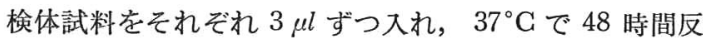
応させ, 出現した沈降輸の直径を測定した. なお使用し た精製 $\operatorname{IgG}, \operatorname{IgG}(\mathrm{T}), \operatorname{IgM}$ 抢よびその特異抗血清は当教 室で作製した。

寒天免疫電気泳動は右田の方法に準じた.

\section{結果および考察}

分婏時母馬血清, 出産直後および哺乳後の新生子血清, さらに初乳乳清についての抗馬全血清を用いた免疫電気 泳動像 (Fig. 1.) から, 出生直後新生子血清には IgG,

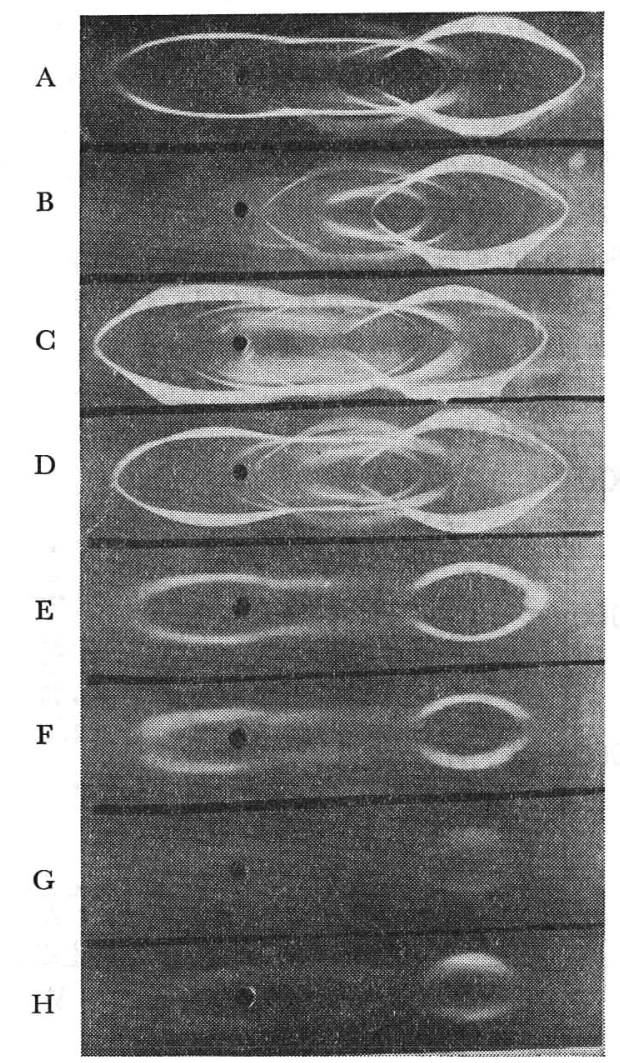

Fig. 1. Immunoelectrophoretic patterns of mother serum, new born serum, and whey.

A: Mother serum. B: New born serum of precolostrum. C: Whey of colostrum at birth. D: New born serum 12 hours after feeding colostrum. E: Whey 36 hours after birth. F: Whey 3 days after birth. G: Whey 7 days after birth. H: Whey 2 months after birth.

$\operatorname{IgG}(\mathrm{T}), \operatorname{IgM}$ の沈降線は認められず，多量の Ig 成分を 含んだ分婏直後の初乳を摂取して始めて新生子血中に Ig が出現する. 分娩後 36 時間の乳にはすでに極めて僅 かしか Ig が含まれていないととがわかった。

Single radial immunodiffusion で定量した馬血清中の Ig の動態 (Fig. 2., 3., 4.) から, 馬は出生直後は IgG, IgG(T), IgM が血中にほとんどなく, 初回の哺乳後 3 洔 間で血中に入り生体内に分布してゆき，24３6 時間で 最高値に達した。 


\section{（108）生物物理化学}

初乳により新生子血中に移行した母馬由来の各 Ig の 減衰曲線は Fig. 5. に示すごとく，初期では体内に分布 するまでの間は 2 次式の形で減少し, 平衡に達した後直 線的に 1 次式の形で消費される. $\operatorname{IgG}, \operatorname{IgG}(\mathrm{T}), \operatorname{Ig} M$ に ついてそれぞれの半減期は 180 日，25 日，13 日であり， $\mathrm{S}=\mathrm{S}_{0} \mathrm{e}^{-\mathrm{kt}}$ で示されるKの值はそれぞれ 0.004，0.025， 0.035 であった. 哺乳直後新生子体内へ Ig が分布する動 態は, Fig. 5. に示すように実際曲線值から平衡後の減衰 曲線の延長線值を差引いて得られた曲線として表わされ る. この哺乳直後の Ig の新生子体内への分布動態は免 疫学的にみて何らかの意味があるかも知ない。

子馬血中 Ig の最少值を示す時期は Ig の種類によっ て異なり, IgG は生後 5,6 力月, $\operatorname{IgG}(\mathrm{T})$ は 1 力月, IgM は 1 週間であった。．乙れらの時期までには少なくとも

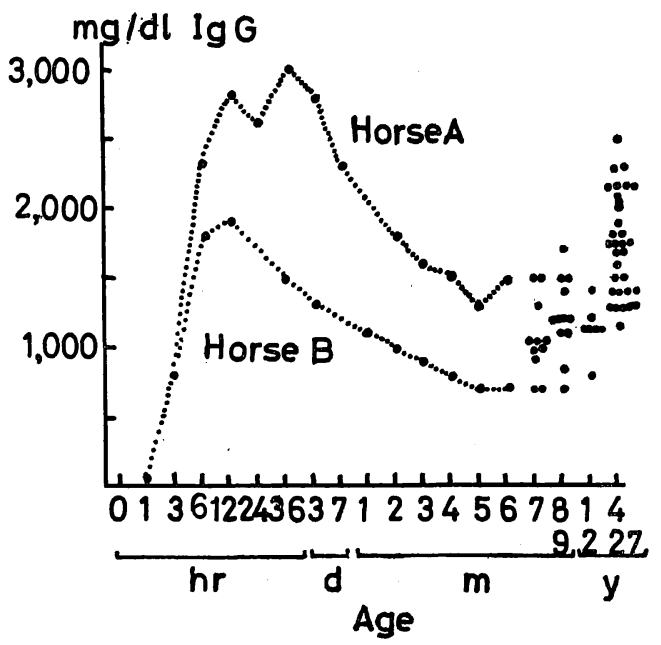

Fig. 2. Change with age of horse serum IgG. A : Young horse A. B: Young horse B.

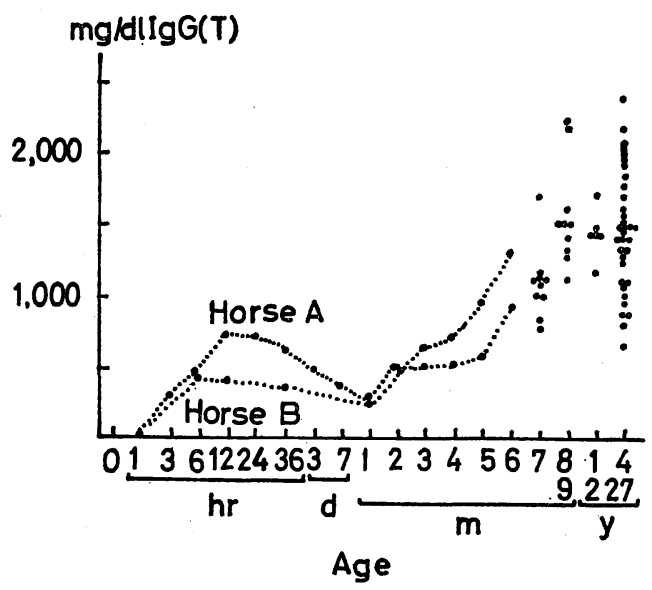

Fig. 3. Change with age of horse serum $\operatorname{IgG}(\mathrm{T})$.

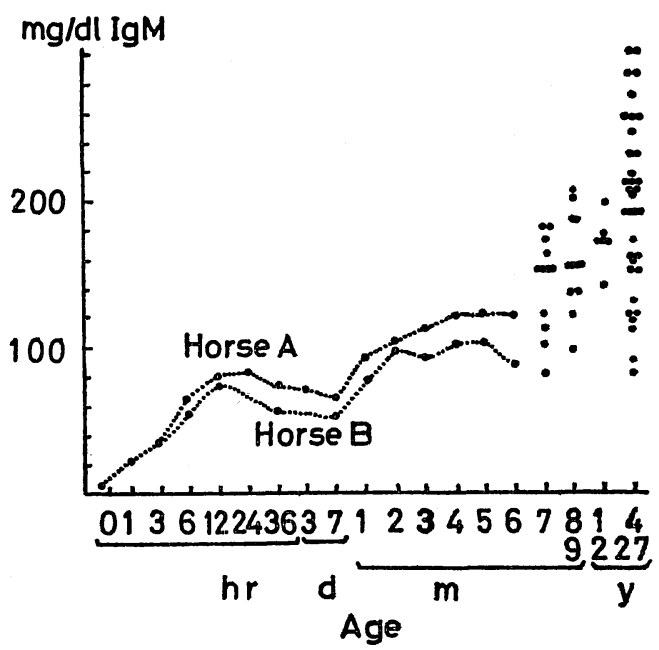

Fig. 4. Change with age of horse serum $\operatorname{IgM}$.

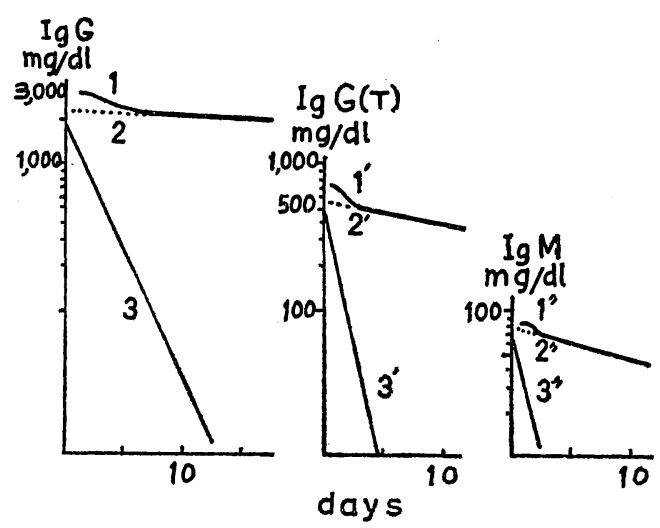

Fig. 5. Numerical analysis of time course of decrease in serum immunoglobulins in a young horse after feeding colostrum.

$$
\begin{aligned}
& \operatorname{IgG} \begin{cases}1: & \mathrm{S}_{\mathrm{G}}=2.250 \mathrm{e}^{-0.004 \mathrm{t}}+1,900 \mathrm{e}^{-0.37 \mathrm{t}} \\
2: & \mathrm{T}_{1 / 2}=180, \mathrm{k}=0.004 . \\
3: & \mathrm{T}_{1 / 2}=1,7, \mathrm{k}=0.37\end{cases} \\
& \operatorname{IgG}(\mathrm{T}) \begin{cases}1^{\prime}: & \mathrm{S}_{\mathrm{T}}=550 \mathrm{e}^{-0.025 \mathrm{t}}+370 \mathrm{e}^{-0.64 \mathrm{t}} \\
2^{\prime}: & \mathrm{T}_{1 / 2}=25, \mathrm{k}=0.025 \\
3^{\prime}: & \mathrm{T}_{1 / 2}=1, \mathrm{k}=0.64\end{cases} \\
& \operatorname{IgM} \begin{cases}1^{\prime \prime}: & \mathrm{S}_{\mathrm{M}}=80 \mathrm{e}^{-0.053 \mathrm{t}}+65 \mathrm{e}^{-0.64 \mathrm{t}} \\
2^{\prime \prime}: & \mathrm{T}_{1 / 2}=13, \mathrm{k}=0.053 \\
3^{\prime \prime}: & \mathrm{T}_{1 / 2}=1, \mathrm{k}=0.64\end{cases}
\end{aligned}
$$

それぞれの Ig の産生が子馬体内で始まっていると考え られる. その後, IgGは2才まで低值を保ち, 3 才を境に 著增し, $\operatorname{IgG}(\mathrm{T}), \operatorname{IgM}$ は生後 7,8 力月でほぼ成馬值に近 づくことがわかった．また 4 才以上の成馬では血中 Ig は変動はあるが，年令的変化は認められなかった，乙の ような馬血滑 Ig の量的変化を考慮することは育成期に 
おける馬の免疫学的疾患を取り扱う場合大いに参考にな るであろう.

\section{8. 人炭酸脱水酵素 : Multiple isozymes}

\section{船越 哲}

（北大・医・第 1 生化学，ミドリ十字（株)）

Deutsch, H.F.

（ウイスコンシン大・医・生理化学）

\section{平井 秀松}

(北大・医・第 1 生化学)

人赤血球中に存在する炭酸脱水酵素 $(\mathrm{CA})$ は，分子量 約 30,000 で，分子中 1 モルの亜鉛を含有し，炭酸イオ ンの平衡を司る䤉素として知られて以来，1966 年迄に $\mathrm{CA}-\mathrm{B}, \mathrm{C}$ 及び A の 3 種のアイソザイムとして単離され, 多くの一般物理化学的性状が明らかにされた。

私達は DEAE セルロースによるカラムクロマトグラ フィーを低イオン強度で行ない，人赤血球よりてれら 3 種のアイソザイムに加えて更に微量の 10 種のアイソザ 1ム CA-D, E, F, G, H, M, N, O, P 及びTを単離し, 内 8 種を結晶としてえた。

これらアイソザイムは，免疫学的にはいずれも主要酵 素 $\mathrm{B}$ 又は $\mathrm{C}$ 型電することがわかった．免疫学的に同一 の型に属するアイソザイムの間では，アミド含量の相違 に基づく等電点の差以外には，酵素活性，亜鉛含量，ア ミノ酸組成, 分子量等の性状の間に差異は認められなか った.

$\mathrm{CA}$ アイソザイムは， $\mathrm{pH} 12.6$ のアルカリ溶液中 $-12^{\circ} \mathrm{C}$ で殆んど瓷性を伴うことなく $\mathrm{CA}-\mathrm{B} \rightarrow \mathrm{A} \rightarrow \mathrm{D} \rightarrow \mathrm{T}$ 等の変掺が起ることが見出され，それは分子中グルタミ ン或いはアスパラギンのアミドを 1 個ずつ放出してゆく ことによるあのであることが明らかにされた，一方 ${ }^{65} \mathrm{Zn}$ 交捘反応，殿粉ゲル電気泳動及び Ouchterlony 法 を組合せた実験で，てれらア.イソザイムは in vivo に存 在すると推定し得る結果を得た。

CA 微量アイソザイムが in vitro で転換により産生さ れる一方，in vivo にも存在するということは，in vivo で代謝過程に扣いて産生されている可能性が考えられる。 遠心分離法によって老若赤血球を分画し，それぞれに等 電点分画法を適用し， 1 元免疫搪散定量法によってアイ ソザイムの分布を求めた結果，微量アイソザイムは若赤 血球に比して老赤血球中に多量に存在するてとが明らか にされた。

殿粉ゲル電気泳動と免疫学的手法とを組合せた方法で スクリーニングすることにより，55 検体のうち 1 検体
の白人にミュタントアイソザイムを見出し，てれを PMUT と名付け，単離精製して結晶となし， CA-B との 易動度の違いは分子中 1 個のアミノ酸の置換によるもの であることがわかった．同様にして 200 検体以上のアメ リカンニグロの赤血球中，殿粉ゲル電気泳動によるスク リーニングで， $\mathrm{G}$ 型の微量アイソザイム $\mathrm{CA}-\mathrm{H}$ と易動 度が類似のアイソザイムを多量に有する個体を見出し， これを仮に $\mathrm{CA}-\mathrm{H}$ と呼び， $\mathrm{CC}, \mathrm{CH}, \mathrm{HH}$ の出現頻度が メンデルの法則に従っていそうなととから，現在てれの 遺伝学的な面に興味があたれている.

殿粉ゲル電気泳動法による各種動物赤血球中 GA ア イソザイムの分布，1 元免疫拡散定量法による各種疾病 と血中 $\mathrm{CA} レ$ レルとの関係についてなど，少しずつ明ら かにされつつある.

以上の結果の詳細は，8 報の論文として，そのうちの 1 部は J. Biol. Chem. 及び J. Lab. Clin. Med. に発表さ れ，他は近日中に発表される予定になっている。

\section{9. 薄層ポリアクリルアミドゲル等電点分 画法によるラットのエノラーゼアイン ザイムの検出}

\section{浅賀 久照・紺野 邦夫 \\ (昭和大・医・生化学)}

家鬼筋エノラーゼと肝ェノラーゼは等電点分画，耐熱 性及び免疫学的に区別しうるととが認められている．今 回は薄層ポリアクリルアミドゲル内等電点分画法を用い てラットの各種臟器のエノラーゼアイソザイムパターン を検討した。

\section{実 験 方 法}

試料の調製は臓器 $1 \mathrm{~g}$ 当り $5 \mathrm{~m} l$ の $0.05 \mathrm{M}$ imidazoleHCl buffer, pH 7.5 を加え homogenize 後 $18,000 \times g$, 30 分間遠沈しその上清を得た. 薄層ポリアクリルアミ ドゲルは厚さ $0.1 \mathrm{~cm}$, 幅 $8 \mathrm{~cm}$, 長さ $18 \mathrm{~cm}$ からなり, $4 \%$ アクリルアミド， $2 \%$ carrier ampholyte を含む. 直径 $2 \mathrm{~mm}$ の炭素棒を $16 \mathrm{~cm}$ 離しておきての上に試料 を中央に $1 \mathrm{~cm} \times 2 \mathrm{~cm}$ の大きさに置いたゲル板をのせる. 陽極の炭素棒はリン酸溶液, 陰極の炭素棒はエチレンジ アミン溶液に予めつけておいたすのを使用した，通電は

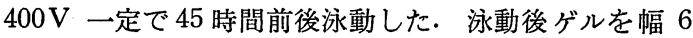
$\mathrm{mm}$, 長さ $10 \mathrm{~mm}$ の大きさに切り出し直ちに飽和硫安 液につける. (ゲルは予め 2 枚の汇紙の間にはさみ切片を 鋏で切り出す.) 1 晚放置後, 切片を軽く蒸溜水で洗い水 分を切り $3 \mathrm{ml}$ の反応液につけ $30 \sim 120$ 分間 incubation 
（110）生物物理化学

後, 水を blank にして波長 $340 \mathrm{~m} \mu$ の吸光度を测定した. 反応液は $3 \mathrm{ml}$ 中に 2 -phosphoglyceric acid $2.2 \mu$ mole, $\mathrm{Mg}^{\#} 3.0 \mu$ mole, ADP $0.3 \mu$ mole, NADH $0.25 \mu$ mole, ピルビン酸キナーゼ 1.5 I.U., 乳酸脱水素酵素 0.8 I.U. (0.05 M imidazole-HCl buffer, $\mathrm{pH} 7.5$ 中) を含む.

\section{実 験 結 學}

肝エノラーゼは fraction No. 16 及び 21 につの活性 バンドを認めた．とれはサンプルの塗布位置を変えても 変化しなかった (Fig. 1.). 筋エノラーゼは fraction No.

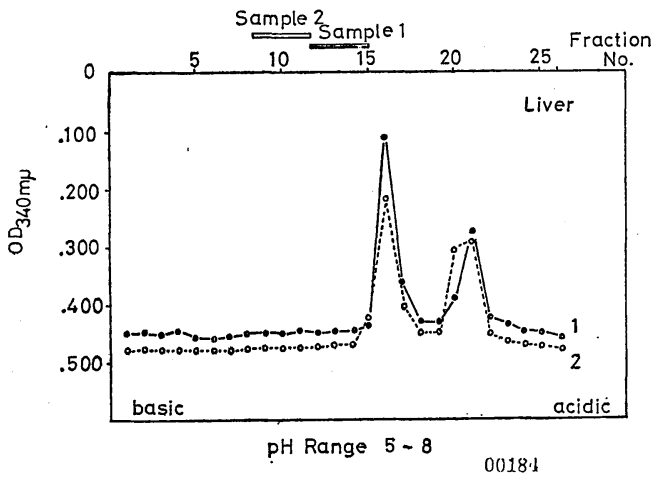

Fig. 1. Gel electrofocusing of liver enolase with two different sampling positions.

6, 及び 8 に大きな活性 band, 更に No. 17 付近にもわず かな活性バンドを認めた (Fig. 2.). 肝エノラーゼと同型

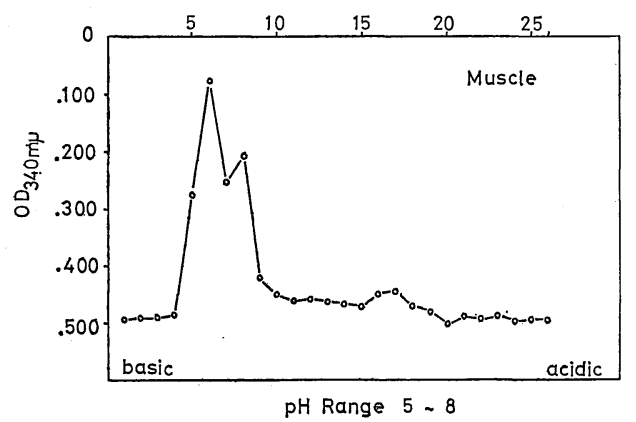

Fig. 2. Gel electrofocusing of muscle enolase.

のものは肺, 腎, 小腸, 萃臓, 脳, 心筋に認めた. 筋肉に あわずかに存在するようである. 小腸では肝エノラーゼ と同型のあのの他，更に筋エノラーゼよりあ酸性側にも う 1 つの活性バンドを認めた (Fig. 3.). 脳エノラーゼは 肝エノラーゼと同型のむのの他に更に酸性側にもう $1 つ$ の活性バンドを認めた (Fig. 4.). 以上のエノラーゼアイ ソザイムが代謝上いかなる意味を持っているかは不明で

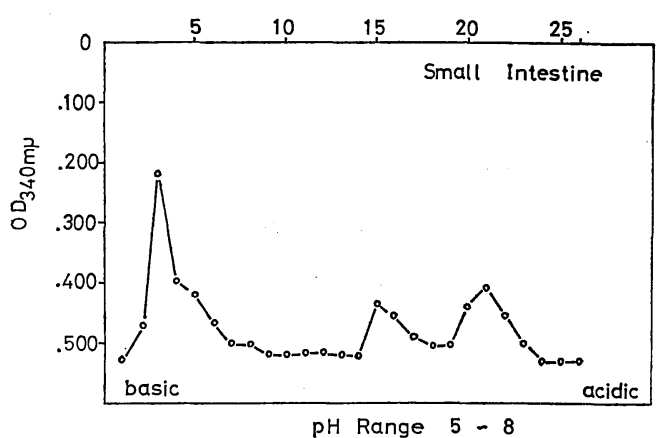

Fig. 3. Gel electrofocusing of intestine enolase.

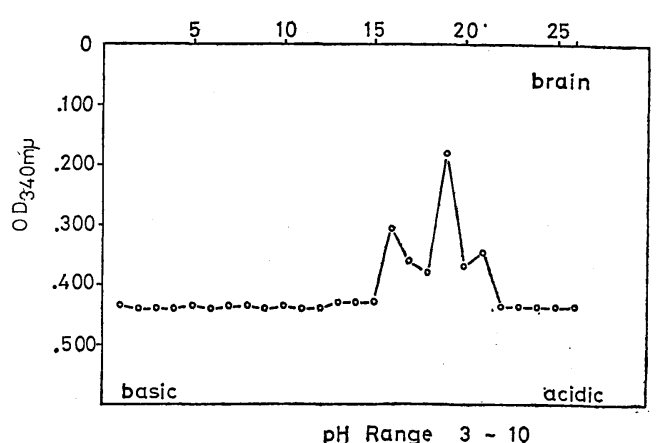

Fig. 4. Gel electrofocusing of brain enolase.

あるが，臓器により gene control を別にしたアイソザイ ムであろうと考えられる。

\section{Electrofocusing による血清蛋白分画 に関する研究（第 4 報） \\ 血清アルカリフォスファター ゼについて—}

\section{中野 良昭・福田 守道 \\ （札幌医大 ・癌研 -内科）}

血清アルカリフォスファターゼ（以下 AP と畧記）の isoenzyme については,すでに各種電気泳動法により検 討され, その臓器由来, 疾患による変動についても多く の報告がある.われわれは先年来等電点分画法による人 血清蛋白分画成績につき報告してきたが，今回は血清 AP につき Disc 電気泳動法, ゲル内等電点分画法 (GEF と畧記）扣よび等電点分画法（EF と畧記）による分画 態度を対比检討したので予報的に報告する.

\section{実 験 方 法}

Disc 電気泳動法は Smith $^{1)}$ らにならい，5\% polyacrylamide gel, Tris borate buffer, pH 9.5 を使用し血清試 
料 $50 \mu l$ を $270 \mathrm{~V}, 40$ 分間泳動後, $\alpha$-naphthylphosphate を substrate とし，Fast blue RR salt を diazonium salt として borate buffer, pH 9.7 亿て室温で 1 時間反応さ せ酵素染色を行なった (Table 1.).

GEF はほぼ既報の方法 ${ }^{2)}$ (Table 2.) によったが Ampholine による AP の失活を考虑し, あらかじめ $\mathrm{Zn}^{+}$ を最終濃度 $1 \mathrm{mM}$ となるように添加し, Disc 電気泳動 装置により $300 \mathrm{~V}, 14$ 時間泳動した. 酵素染色にはnaphthol AS-MX phosphate を substrate として Fast red LB salt にて行なった. EF は LKB 社製 Ampholine column 8101, 容量 $120 \mathrm{ml}$ の屯のを使用し, $\mathrm{pH}$ 3-10 域 Ampholine 終濃度 $1 \%$, 蔗糖浱度勾配中で $4^{\circ} \mathrm{C}, 400 \mathrm{~V}$, 48 時間泳動し, 終了後 proportioning pump (Technicon 社製）により溶出を行ないながら同時にそのまま autoanalyzer により AP 活性の自動測定を行ない, かつ Sampler II により分画採取した. $\mathrm{pH}$ 測定は Beckman Expandomatic $\mathrm{pH}$ meter SS-II により $20^{\circ} \mathrm{G}$ にて行な

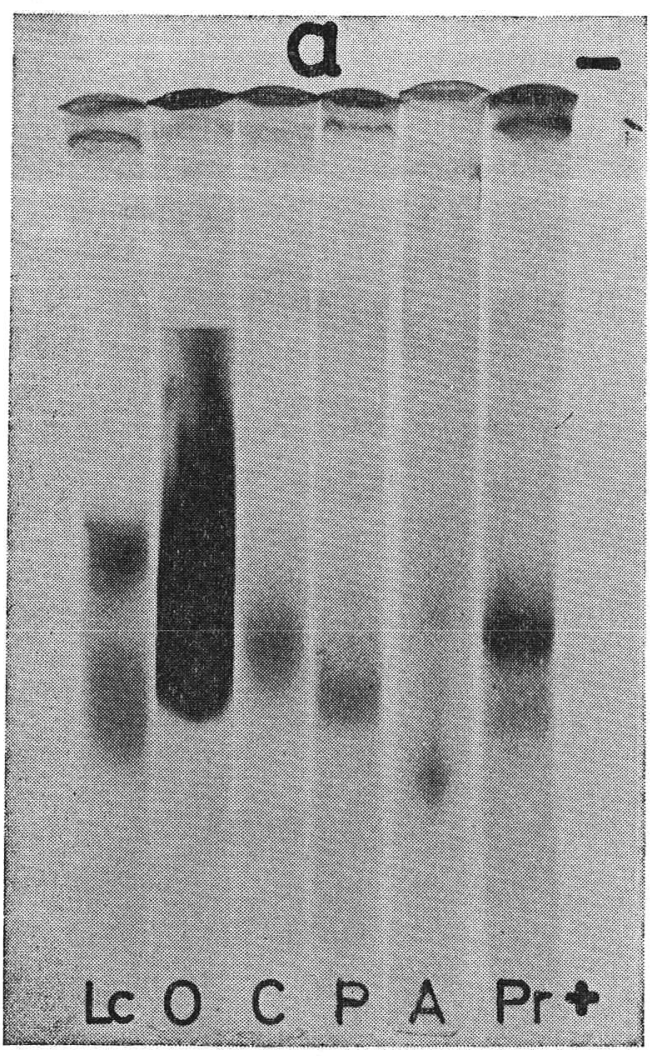

Fig. 2 (1). Alkaline phosphatase isoenzyme by disc electrophoresis. LG: Liver cirrhosis. O: Osteogenic sarcoma with metastasis to the lung. C: Cord serum. P: Gastric carcinoma. A: Ascites (gastric carcinoma). Pr: Late pregnancy. $\mathrm{N}$ : Normal serum. 


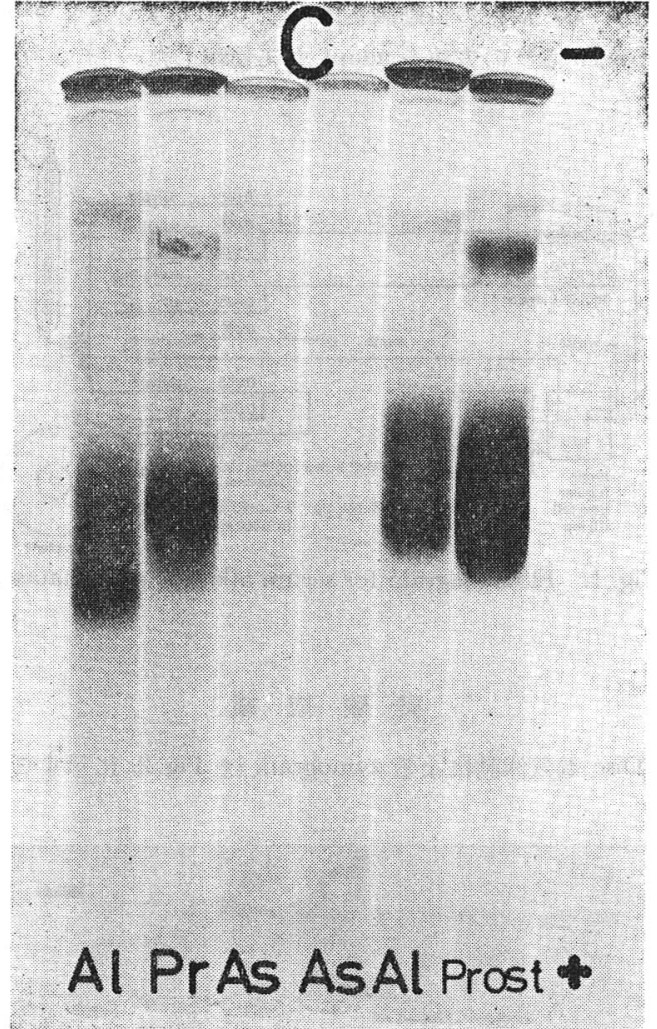

Fig. 2 (2). Alkaline phosphatase isoenzyme by disc electrophoresis.

Al: Acute leukemia.

Pr: Late pregnancy

As: Ascites (gastric carcinoma).

Prost: Prostatic tumor with liver and bone marrow metastasis.

くほぼ Smith ら ${ }^{1)}$ の報告に一致した成績が得られた。 Fig. 2, a-c は肝硬変症, 骨肉腫肺転移例, 臍带血血清, 胃癌兼癌性腹膜炎の血清扰よび腹水, 妊娠後期血清, 急 性骨㵦性白血病および正常人血清であるが，易動度の速 い側より, 肝, 骨, 胎盤, 小腸由来の AP と推定された. な拉肝，骨転移を有する前立腺癌患者血清汃らは，きわ だって易動度の遅し活性帯が検出された.

GEF による分画成績では (Fig. 3.) まず $\mathrm{pH}$ の低い側 の一定の部位から電極液倒に失活がみられるが，それよ り中性側で内部にそれぞれ数ケの活性帯をふくむ 2 本の 幅広い活性帯がみられる. GEF では carrier ampholytes が chelation により $\mathrm{Zn}$ \# を奪うため酵素活性の失活を 生じるが，乙れを防止するため $\mathrm{Zn}$ "をあらかじめ添加 して分離を行なっても $\mathrm{pH} 3.7$ 以下の酸性側の醭素活性 はみとめられなかった. GEF では酳素活性の定量化が 容易でなくまた $\mathrm{pH}$ の正確な測定む不能であるのでさら
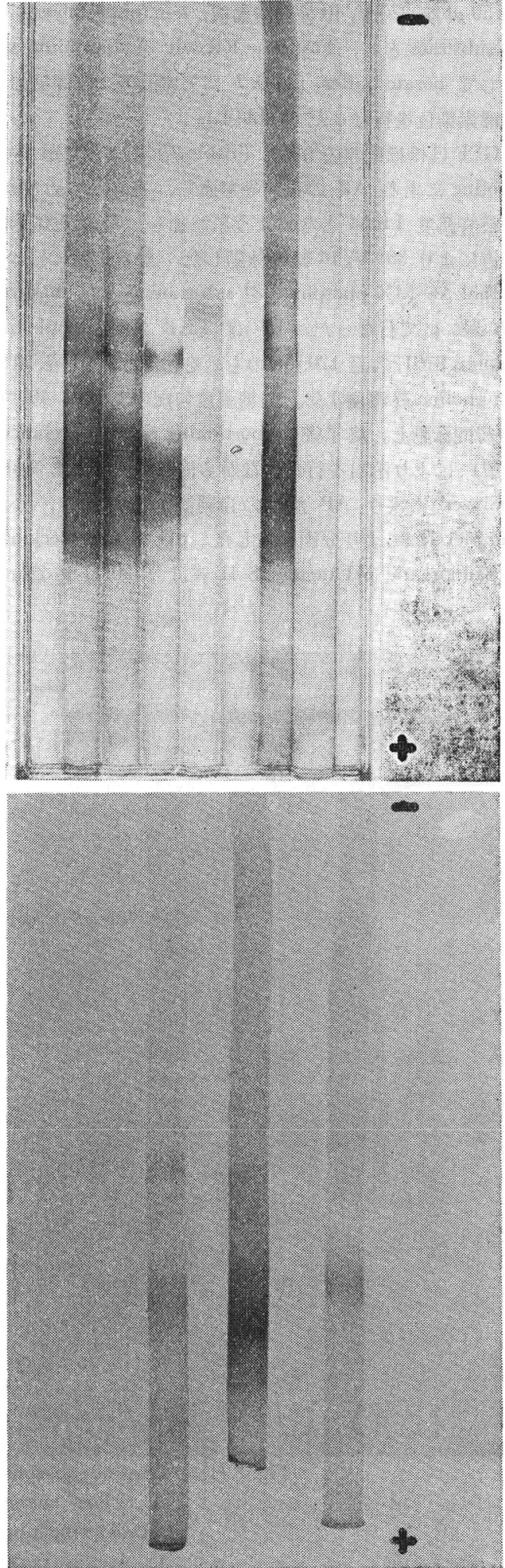

Fig. 3. Gel electrofocusing of serum alkaline phosphatase. 
に通常の $\mathrm{EF}$ により血清 $\mathrm{AP}$ の分離を試み, 活性の自動 測定, $\mathrm{pH}$ の測定を行なった.

すでに Latner ら ${ }^{4)}$ は $\mathrm{pH}$ と $\mathrm{Zn}^{+}$濃度が酵素活性に およぼす影響につき検討し， AP が EF による分画後, 低 $\mathrm{pH}$ 域掞よび $\mathrm{Zn}$ " chelation により著明な失活を来す こと，透析扣よび $\mathrm{Zn}{ }^{+}$添加により活性の復活をみるこ とを報じている.

われわれもほぼ同様の成績を得たが，分函によっては $\mathrm{Zn}^{+}$を加えることによりむしろ活性の上昇を認めるむ のああり AP の re-dimerization との関連む考えられる が詳細は現在検討中である.

Fig. 4. は正常人血清 AP の分画成績を示すが pI は

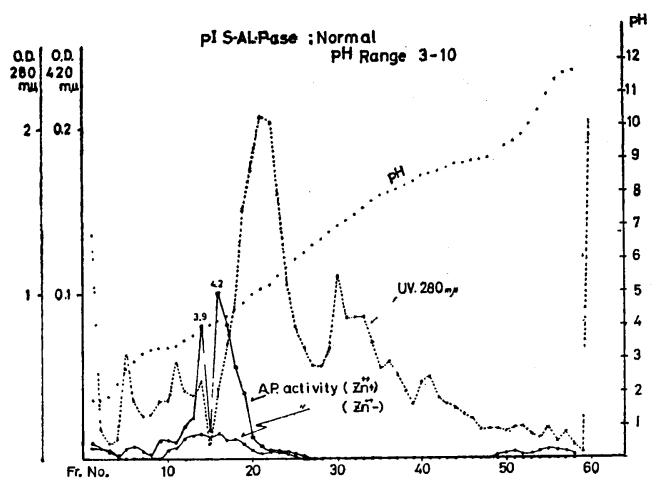

Fig. 4. Isoelectrofocusing of serum alkaline phosphatase.

-O-O-: Activity without $\mathrm{Zn}^{+}$ion.

- - Reactivation by $\mathrm{Zn}^{\mathrm{H}}$ ion.

3.9，4.2 亿一致した. 肝癌，肝炎のパターンは Fig. 5., 6. 亿示すごとくほぼ類似の成績を得た. Fig. 7. は骨肉腫 肺転移例のあのであるが pI 4.0,4. 3 亿高い活性があり,

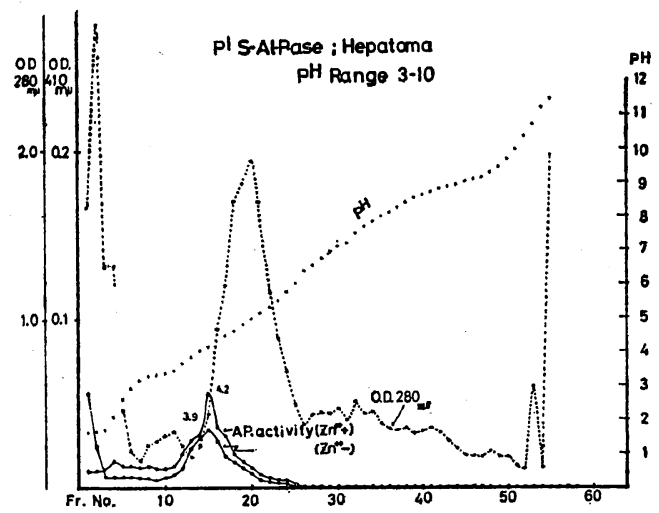

Fig. 5. Isoelectrofocusing of hepatoma serum alkaline phosphatase.

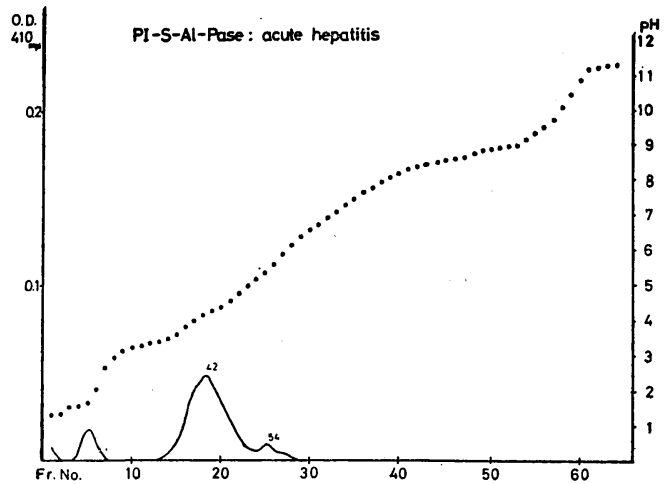

Fig. 6. Isoelectrofocusing of hepatitis serum alkaline phosphatase.

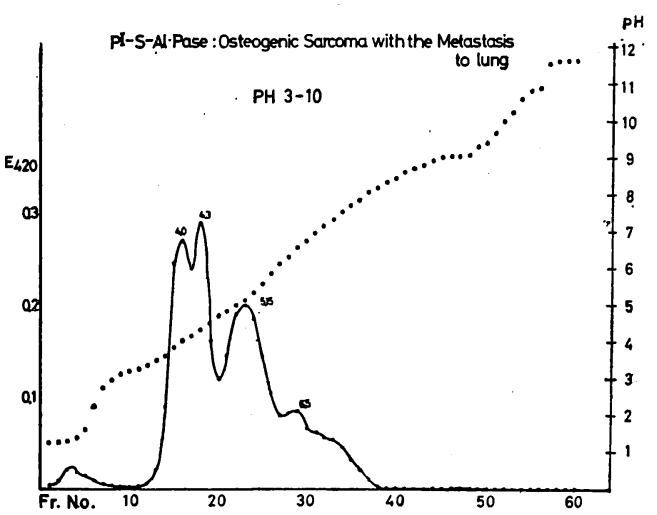

Disc electrophoresis of each fractions

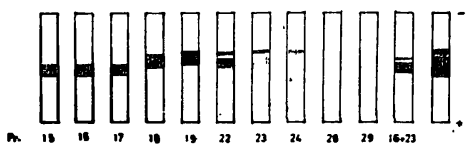

Fig. 7. Isoelectrofocusing of serum alkaline phosphatase in osteogenic sarcoma with the metastasis to the lung.

\subsection{5，6.5 亿も活性が認められた。}

現在 narrow pH range の Ampholine を作製，検討中 であるがこれにより血清 AP の microheterogeneity は より一層明瞭になるむのと期待される．以上血清 AP の Disc 電気泳動法，GEF，EF，による分離成績につき述べ たが, 今後てれら AP pI isoenzyme の臟器起源, microheterogeneity の由来につき引き続き検討の予定である. 
Table 1. Disc electrophoresis procedure ${ }^{1)}$.

\section{Reagents}

1. Tris borate TEMED solution

$$
\begin{aligned}
& \text { Tris } 45.5 \mathrm{~g} \\
& \text { TEMED } \quad 1.2 \mathrm{ml} \\
& \mathrm{H}_{2} \mathrm{O} \text { to } 1,000 \mathrm{ml} \\
& \text { pH adjusted to } 9.5 \text { with boric acid. }
\end{aligned}
$$

2. Tris borate buffer $\mathrm{pH} 9.5$

dilute 1: 4 before use (electrode vessel).

3. Gel monomer

$\begin{array}{lr}\text { Acrylamide } & 19 \mathrm{~g} \\ \mathrm{BIS} & 1 \mathrm{~g} \\ \mathrm{H}_{2} \mathrm{O} & \text { to } 100 \mathrm{ml}\end{array}$

4. $0.2 \%$ Persulfate solution

Gel: $1: 3: 4=1: 1: 2$, Tube: $0.7 \times 6.0 \mathrm{~cm}$

Condition: $270 \mathrm{~V}, 3 \mathrm{~mA} /$ tube, $40 \mathrm{~min}$.

Staining: $\alpha$-naphthyl phosphate in boric acid, $\mathrm{MgCl}_{2}$ solution ( $\mathrm{pH}$ 9.7) and fast blue R.R. salt.

Table 2. Gel electrofocusing procedure for serum alkaline phosphatase.

Catalyst solution

$\begin{array}{lr}\text { TEMED } & 1 \mathrm{~m} l \\ \text { Riboflavin } & 14 \mathrm{mg} \\ \mathrm{H}_{2} \mathrm{O} & \text { to } 100 \mathrm{ml}\end{array}$

Acrylamide solution

$\begin{array}{lc}\text { BIS } & 0.8 \mathrm{~g} \\ \text { Acrylamide } & 30 \mathrm{~g} \\ \mathrm{H}_{2} \mathrm{O} & \text { to } 100 \mathrm{ml}\end{array}$

Gel mixture

$\begin{array}{lc}\text { Catalyst solution } & 4 \mathrm{~m} l \\ \text { Acrylamide solution } & 15 \mathrm{~m} l \\ \text { Ampholine (pH 3-10) } & 1.5 \mathrm{~m} l \\ \mathrm{H}_{2} \mathrm{O} & \text { to } 41 \mathrm{~m} l\end{array}$

$\left(\mathrm{ZnCl}_{2}\right.$ added to final concentration of $\left.1 \mathrm{mM}\right)$

Sample: $0.2 \overline{\mathrm{m} l}$ serum per tube.

Photopolymerization.

$$
\text { 文献 }
$$

1) Smith, I., et al.: Separation of human tissue alkaline phosphatase by electrophoresis on acrylamide disc gels, Clin. Chim. Acta, 19, 499 (1968).

2) 福田守道, 片山吏司, 漆崎一朗 : Electrofocusing 飞 よる血清蛋白分画に関する研究. III, SLDH pI isozyme について, 生物物理化学, 15, 246-249(1971).

3) Morgenstern, et al.: Clin. Chem. 11, 876 (1965).

4) Latner, L., et al.: Isoelectric focusing of human liver alkaline phosphatase, Biochem, J. 118, 229 (1970).

\section{1. 実験的肺動脈咨ネズミにおける組織 LDH 及びそのアインエンザイムの 変動について}

$$
\begin{aligned}
& \text { 本間 濶・本間紀久雄 } \\
& \text { 五十嵐丈記・村尾 誠 } \\
& \text { (北大・医・第 } 1 \text { 内科) }
\end{aligned}
$$

肺動脈炎は肺高血圧を惹起し，強い右心肥大により慢 性肺性心となり，うっ血性心不全に至らしめる疾患の一 つである.今回我々は“肺高血圧症惹起植物”として知 られていタヌキ豆科の 1 種である Crotalaria spectabilis 種子添加食䬣により，ラットに肺動脈炎を作成し，次の 様な実験を行なった。

\section{実 験 方 法}

実験材料は幼若雌性 Wistar albino rat（体重 50〜100 g）を用いた. とれをA群：対照群 10 匹，B群：Crotalaria spectabilis 種子 $0.05 \%$ 含有食䬣群 16 匹, $\mathrm{C}$ 群： 同種子 $0.1 \%$ 含有食慨群にわけた。なお実験期間はB 群 は昨年 12 月中旬より本年 2 月中旬, $\mathrm{G}$ 群では 2 月中旬 より 3 月中旬であった.

ラットはネンブタール麻酔下にて開胸，心穿刺にて採 血後, 肺, 肝, 腎, 心の各臟器を摘出, 組織 $100 \mathrm{mg}$ に 生食を $2 \mathrm{cc}$ の割合で加え, 水水中にて $500 \sim 1,000 \mathrm{rpm}$ にて 5 10 分間 ホモジェナイズし, 更に冷却高速度遠 心機を用い, $0 \sim 5^{\circ} \mathrm{C}$ にて約 $25,000 \times g 20$ 分間遠沈，そ の上清を用いた. LDH 活性值は Wróblewski 変法であ る Bergmeyer 法により測定し， $1 \mathrm{~g}$ 湿組織あたりの活性 值を Wróblewski 単位で表わした. LDH アイソェンザ イムは吉田等の寒天電気泳動法により分離し, LDH 染 色は tetrazolium 塩還元法によった。 LDH は陽極側よ り $\mathrm{LDH}$ 1, LDH 2 の順とし, 分画比を $570 \mathrm{~m} \mu$ でデン シトメトリーを行なって求めた. 分画別活性值は $\mathrm{LDH}$ 活性值に分画比を乗じて, 又 LDH M subunit の活性百 分率はアイソェンザイムの分画比より計算によりあとめ た. 
成

績

B 群， $\mathrm{C}$ 群のラットはとあに末期において (40 55 日 目）食欲不振，呼吸困難，チアノーゼを呈した。剖検で は胸水, 腹水の貯溜, 心肥大, 肝, 腎のうっ血などがあ り, 肺は硬く胸膜面は出血斑のはんもん状を呈し, 浮腫 状であった．組織学的には，肺動脈炎を主体とする肺の 病変, 右心室筋肥大, 肝の小葉中心性うっ血, 腎のうっ 血等を認めた. $\mathrm{B}$ 群と $\mathrm{G}$ 群を比較すると肺の変化は $\mathrm{G}$ 群 に他の臟器の変化及び一般状態はB 群に強くみられた.

肺における LDH 活性值はB群において, 中間期に比 較的高值を示すが，その後ではむしろ低值を呈した，G 群においてはより早期に高值を示し, 以後若干の変動後, 末期では低值であった. アイソエンザイムの分画別活性 值の変動は，LDH 5 が主体であった．LDH アイソエ ンザイムパターンは B, C 群ともに相対的な LDH 4,5 の増加と, LDH 3 の減少をみ, M型への移行を示し ている. LDH M subunit の百分率は両群ともに, 軽微 の増加を示した.

肝では LDH 活性值は B 群において次第に増加を示す が，末期では前值に復した．G 群では初期において軽度 の増加を示したが一過性の減少の後, 前值に復した. ア イソェンザイムパターンには変化はみられなかった。

腎においてもB 群では次第に LDH 活性值は上昇し， 中間期に高值を示し，その後減少し末期では対照值より あ低值を示した．Ｇ群は同様の変化がより早期にみられ た. アイソェンザイム分画別活性值は LDH 1, LDH 5, LDH 2, 3, 4 の順で変動をみた. アイソエンザイムパタ ーンは LDH 1 の比較的減少及び LDH 2, 3, 4 の比較的 増加で，M型への移行を示した. LDH M subunit 百分 率は $\mathrm{B}$ 群では末期に， $\mathrm{C}$ 群では中間期にそれぞれ軽度の 増加を示した。

心では LDH 活性值はB 群では 40 日目に 1 時的な 高值を示したが，C 群では早期に著明な高值を示し，そ の後次第に減少の傾向を示したがなお対照に比べ高值を 保った. アイソエンザイム分画別活性をみると，B群で は大きな変動をみないが，G群では $\mathrm{LDH} 1$ と $\mathrm{LDH} 2$ の相対的減少と $\mathrm{LDH} \mathrm{3,4,5}$ の增加がありM型への移行 を示した. LDH M subunit 百分率は両群共に漸増し, 末期にはやや減少の傾向であった。

\section{考按}

今回の成績は Crotalaria spectabilis の濃度, 寒冷の影 響, 各臟器の特異性等により $\mathrm{LDH}$ 活性值及びそのアイ ソエンザイムの変化の程度, 時間的関倸に差があったと 思われる，即ち肺組織での LDH 活性値の上昇は, 肺動
脈炎による 2 次的な血管の変化にもとづく組織の虚血性 変化を主体とする初期の傷害を意味しており，その後の 活性值の低下は, 出血, 壊死等の組織破壊過程の反映を 想像させる．また，アイソエンザイムパターンの変化は 組織 hypoxia に拈りる嫌気性代謝元進を反映してM型 に移行したものと思われる．腎の変化も同様なととを想 像させる.また心における $\mathrm{LDH}$ 活性值の変動は B 群で は主として肺高血圧症による肥大心筋の代謝の反映であ り, G 群では早期に Crotalaria spectabilis の toxic な作 用をうけた代謝機構の変化に，更に肺高血圧症という 2 次的な影響が加味されたため両者の差が大きく出たと思 われる.アイソエンザイムパターンではM型への移行が, 他臟器に比べて著明であるのは, 元来心筋自体では好気 性代謝が主体であり，本実験のように，強い心肥大，う っ血性心不全などにより心筋の組織 hypoxia が高度で あるととを想像させる．また肝の変化は心不全に伴う， うっ血肝の程度を反映していると思われる。

結語

肺高血圧症惹起植物として知られているタヌキ豆科の 1 種 Cratalaria spectabilis 種子食餌ラットに括いて肺動 脈炎を作成し右心不全を起し, 肺, 肝, 督及び心におけ る組織 LDH 及びそのアイソエンザイムの変動について 経時的に検索し，若干の検討を加えた。

\section{2 症例にみられた IgA 結合性 LDH isoenzyme}

長嶺 光隆

(福岡市医師会病院・内科)

血清乳酸脱水素酵素 (LDH) アイソザイムの異常像を 呈した 2 症例に拈いて，その異常分画が血清 $\mathrm{LDH}$ と IgA との結合によって出現するととが証明されたので， その成績を報告する。

\section{症例}

症例 1 (K.M.)：55 才, 男, 10 数年来高血圧症があ り, 循環器系検査のため当院受診. その時の検査で $\mathrm{LDH}$ アイソザイムの異常を発見された. LDH は 560 単位 (正 常 $150 \sim 400)$, 心電図で左室肥大所見が認められる以外, 他の検査所見は異常なかった。

症例 2 (F.A.)：26才, 男, 当院において偶然の機会 に LDH アイソザイム像の異常を発見された. LDH が 450 単位を示した他は各種検查成績に異常は認められな かった. 
尚, 2 症例とも赤血球の LDH アイソザイムは正常で あり,さらに症例 1 の息子, 症例 2 の妹の血清 $\mathrm{LDH}$ ア イソザイムは正常パターンであった.

\section{実 験 方 法}

1. LDH アイソエンザイムの作製法 ${ }^{1)}$

寒天に PVP を加えた支持体で Tris- $\mathrm{HCl}$ buffer を用 いて電気泳動し， lactate-NAD-INT の反応系によって 染色した.

2. 免疫沈降線の $\mathrm{LDH}$ 染色

寒天電気泳動後, $5^{\circ} \mathrm{C}$ において 48 時間免疫反応を行 ない，生食水および phosphate buffer で充分洗滌した 後, 沈降線を LDH 染色した。

3. 薄層ゲル汇過法 ${ }^{2)}$

Sephadex G-200 の $2 \mathrm{~mm}$ 厚さの薄層支持体に血清 $20 \mu l$ を挿入して 4 時間展開したあと, 支持体の上に沪 紙をのせて蛋白成分を吸着させ，汇紙を蛋白染色又は $\mathrm{LDH}$ 染色した. 更に $\mathrm{LDH}$ が展開移動した部位の薄層 部分を切り出し, Tris buffer に溶出させて $\mathrm{LDH}$ 成分 を抽出した.

\section{成績}

2 症例の enzymogram を Fig. 1. に示した. 症例 1 に

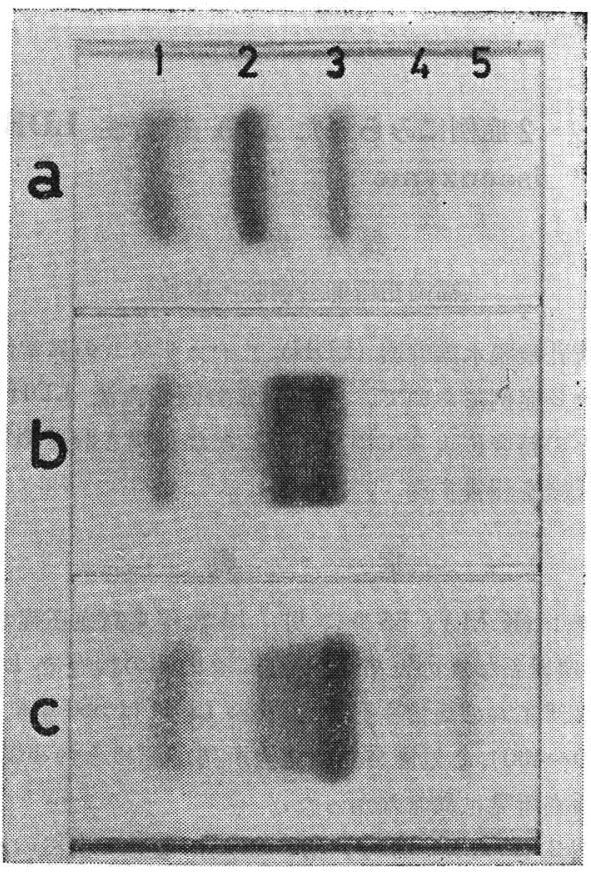

Fig. 1. LDH isoenzyme patterns.

a: Normal serum. b: Serum of the case 1 . c: Serum of the case 2 .

The anode is to the left
おいては LDH-2 が消失して LDH-3 が濃度を増し, そ の陽極側に新しい分画が認められる.症例 2 では LDH-2 の活性が減少して LDH-3 が増加し, 両者の中閒に別の 分画がみられる，薄層ゲル沪過像 (Fig. 2.) では，正常

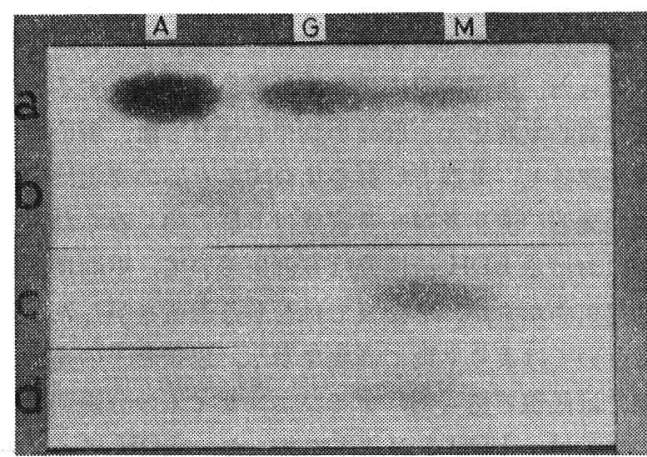

Fig. 2. Thin layer chromatograms of protein and LDH on Sephadex G-200.
a: Protein of normal serum.
b: LDH activity of normal serum.
c: LDH activities of serum from the case 1 .
d: LDH activities of serum from the case 2 .
A: Albumin. G: IgG. M: Macroglobulin.

者の LDH は血清蛋白の $\operatorname{alb}(\mathrm{A})$ と $\operatorname{IgG}(\mathrm{G})$ の中間にの み活性帯 (A-G 成分) を示すのに対して，患者血清の $\mathrm{LDH}$ は 2 例とす $\mathrm{A}-\mathrm{G}$ 成分の他に $\mathrm{IgG}(\mathrm{G})$ とマクログ ロブリン $(\mathrm{M})$ の中閒に別の活性帯 (G-M 成分) が認め られた。

患者血清を抗ヒト全血清 (HWS) を用いて免疫電気泳

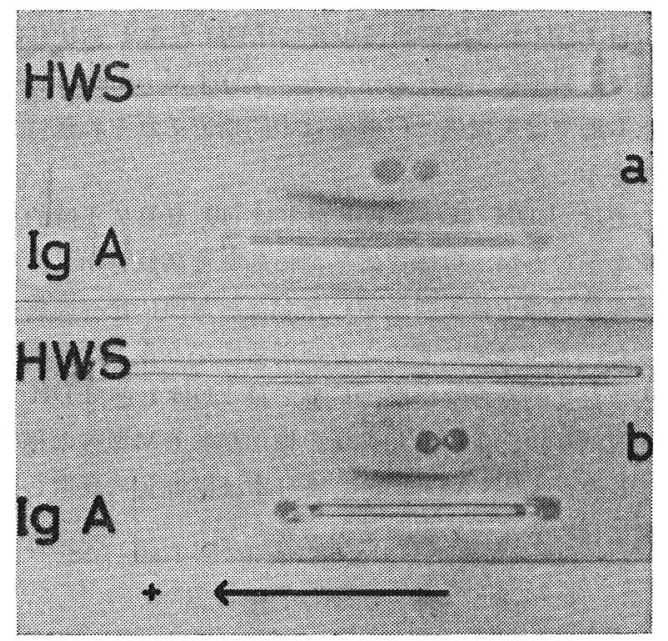

Fig. 3. LDH activities of the immunoelectrophoretic precipitate lines using antihuman whole serum (HWS) and anti-IgA serum (IgA).

a: Serum of the case 1 .

b: Serum of the case 2 . 
動した後, 沈降線を LDH 染色すると LDH 活性を有す る2本の沈降線が得られた (Fig. 3.). そのうち濃い沈降 線は各種特異抗血清による反応によって IgA であると とが証明された。しかし他の沈降線については同定でき なかった。尚，2症例に打ける IgA, IgG, IgM の血中 濃度はいずれも正常範囲であった。

A-G， G-M 成分の抽出液を電気泳動すると症例 1 で は A-G 成分には LDH-1, 3, 4, 5 が，G-M 成分には異 常活性帯および LDH-3 が含まれているととが示された。 症例 2 亿おいては, A-G 成分では LDH-1 LDH-5 を, G-M 成分では LDH-3 のみを検出した. 次に A-G, G-M 成分を免疫電気泳動後 $\mathrm{LDH}$ 染色を行なうと， G-M 成分のみに LDH 活性のある IgA が認められた. 健常者血清に患者の $\mathrm{G}-\mathrm{M}$ 成分を $1: 1 / 2,1,2,4$, の比で 混合し, その混合血清の enzymogram を比較した. そ の結果, G-M 成分の濃度が増すと健常者の LDH-2 分 画が次第に減少し遂には消失して, それに対応して LDH-2 と LDH-3 の中間の異常活性帯が濃度を増す現 象が認められた。

$$
\text { 考按 }
$$

LDH アイソザイムは H(heart) および M(muscle) の subunit の組合わせで成立する四量体であり, subunit は 夫々異なった遺伝子によってコントロールされていると とが証明されている. そして遺伝子の異常によって惹起 された赤血球 LDH アイソザイムの異常例がいくつか報 告されている ${ }^{3,4,5)}$. 近年, このような遺伝子の異常に 由るあのでなく, LDH とある種の蛋白が結合して起と る $\mathrm{LDH}$ アイソザイムの異常例が数例見出され ${ }^{620)}$, Ganrot $^{8)} と$ Biewenga $^{10)}$ は IgA との結合, Kindmark ${ }^{9)}$ は IgG との結合を証明している.

著者の 2 症例においては, ゲル汇過像によって正常 LDH の他倍分子 LDH の存在が示されたので, LDH と或る種の蛋白との結合が推定された，その確認のため， 免疫電気泳動後 LDH 染色を行なったととろ, との蛋白 成分は IgA であるととが判明した。

LDH-IgA の結合が LDH, IgA のいずれの異常によっ て起とるかを検討する目的で患者の IgA 成分と健常者 血清を混合してその LDH 广イソザイムを観察したとこ 万, 正常 LDH-2 が消失して異常活性帯が LDH-2 と LDH-3 の中間に形成されるととが認められた．即ち患 者の LDH の性質は正常であるが，IgA に LDH-2 と 結合する作用が存在するととが明らかとなった.

血清 $\mathrm{LDH}$ 活性值が 2 症例ともやや高值を示している のは, LDH-IgA 結合物がその分子量が大きいために 腎を汇過され難いためか，或いはこの結合物が血中で安
定な状態にあって失活し難いととに由るのではないかと 推定される.

近年, amylase と IgA との結合によって起とる macroamylase の症例が報告されて敄り ${ }^{11,12,13)}$ 本報の LDH-IgA 結合の症例とあわせて，とのような酵素と免 疫グロブリンとの結合を起とす機序ならびにその生理的 意義の解明は今後の興味ある問題である.

\section{文献}

1) 長嶺光隆：臨床病理，投稿中, (1971).

2) 河合 忠, 青木紀生 : 医学のあゆみ, 66, 25 (1968).

3) Boyer, S.H., Fainer, D.C., and Watson-Williams, E. J.: Science, 141, 642 (1963).

4) Nance, W.E., Clatlin, A., and Smithies, O.: Science, 142, 1075 (1963).

5) Syner, F.N., and Goodman, M.M.: Science, 151, 206 (1966).

6) Kreutzer, H.H., Jacobs, Ph., and Francke, C.: Clin. Chim. Acta, 11, 159 (1965).

7) Lundh, B.: Clin. Chim. Acta, 16, 305 (1967).,

8) Ganrot, P.O.: Experientia, 23, 593 (1967).

9) Kindmark, G.-O.: Scand. J. Clin. Lab. Invest., 24, 49 (1969).

10) Biewenga, J., and Thijs, L. G.: Clin. Chim. Acta, 27, 293 (1970).

11) Wilding, P., Cooke, W.T., and Nicholson, G.I.: Ann. Intern. Med., 60, 1053 (1964).

12) Levitt, M.D., and Cooperband, S.R.: New. Eng1. J. Med., 278, 474 (1968).

13) Berk, J.E., Kizu, H., Geller, E., and Fridhandler, L.: Proc. Soc. Expt1. Biol. Med., 131, 154 (1969).

\section{3. 臍帯血の血清 LDH pI isozyme に関 する研究}

\section{福田 守道・片山 吏司・添崎 一朗 \\ （札㹸医大・癌研・内科）}

昨年度本学会において血清乳酸脱水素酵素 (SLDH) の 等電点分画法 $(\mathrm{EF})$ 预よびゲル内等電点分画法 $(\mathrm{GEF})$ に よる分画成績について報告した，従来の電気泳動法によ る成績と異なる多様な分離を示したがその意義および既 報の各分画との対比など未解決の問題む少なくない. 今 回は前回に引き続き各種腫瘍性疾患におけるSLDH の 分画パターンを検討し, 比較的共通して出現する pI isozyme のひとつが脐帯血血清 LDH に見いだされたので その検討成績につき報告する.

\section{実験材料並びに方法}

当科入院中の腫瘍性疾患を含む各種疾患例につき採血, 
(118)

生物物理化学

直ちに血清を分離使用した. 伩帯血血清は分姢直後胎盤 側脐帯より採取した血液より遠心分離使用した。なお母 体血血清は同母体より分娩直前に肘静脈より採血して得 た。 $\mathrm{EF}$ 㐨よび GEF は既報の方法によったが Disc 電 気泳動法は Clark の変法によった.

\section{実 験 成 績}

1）各種腫瘍性疾患の $\mathrm{pI}$ isozyme 分画成績

LKB 製 Ampholine column を使用, $\mathrm{pH}$ 域 3 10 Ampholine $1 \%$, ショ糖濃度勾配中で $4^{\circ} \mathrm{C}, 48$ 時間分画 終了後 peristaltic pump により溶出を行ないながら酵素 活性を Hochella, Weinhouse らの方法の変法により自動 測定を行ない得られた分画パターンは Fig. 1.〜 4. に示 すごとくである，胃癌, 肝臟癌, 子宮癌, 上咽頭癌につ いてはそれぞれに特徵的な分画知見が得られ，従来の Disc 電気泳動所見に比し著しく多彩なパターンを示す ことがあきらかである．特に総活性 3,650 単位と異常高 值を示した上咽頭癌の 1 例では $\mathrm{pH} 4.7,5.1,5.6,6.1$, 6. 4,6.5, 6.8 および 8.6 亿異常に高い活性带の出現が みられ前回報告した seminoma の 2 例之同樣に疾患特異 性を示すすのと考元られる。なお各腫瘍疾患血清に共通

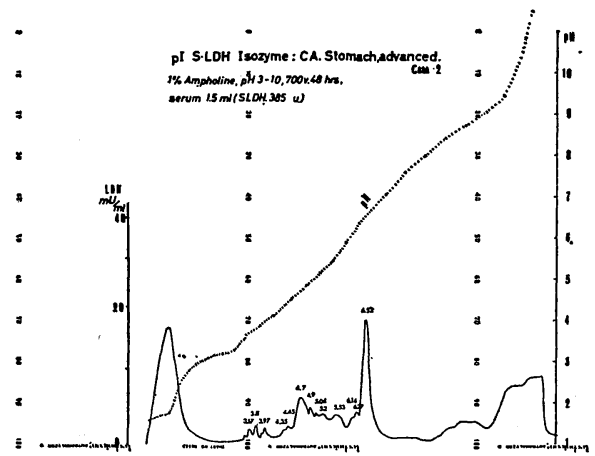

Fig. 1. pI S-LDH isozyme pattern in cancer of the stomach.

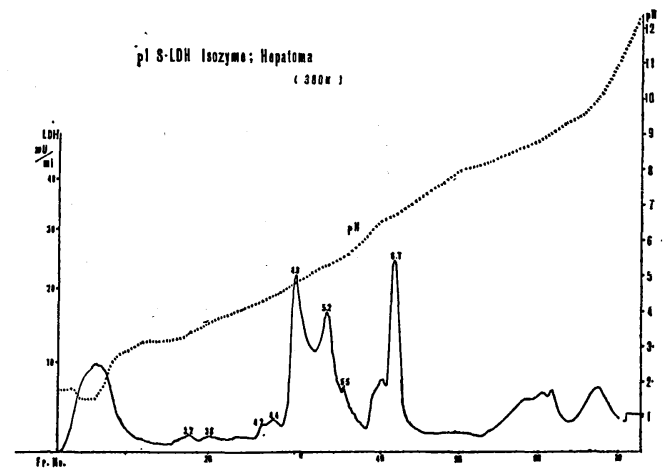

Fig. 2. pI S-LDH isozyme pattern in hepatoma.

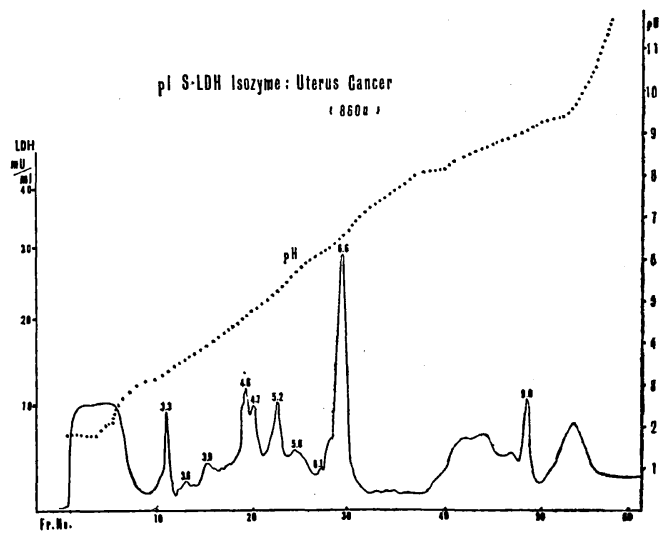

Fig. 3. pI S-LDH isozyme pattern in cancer of the uterus.
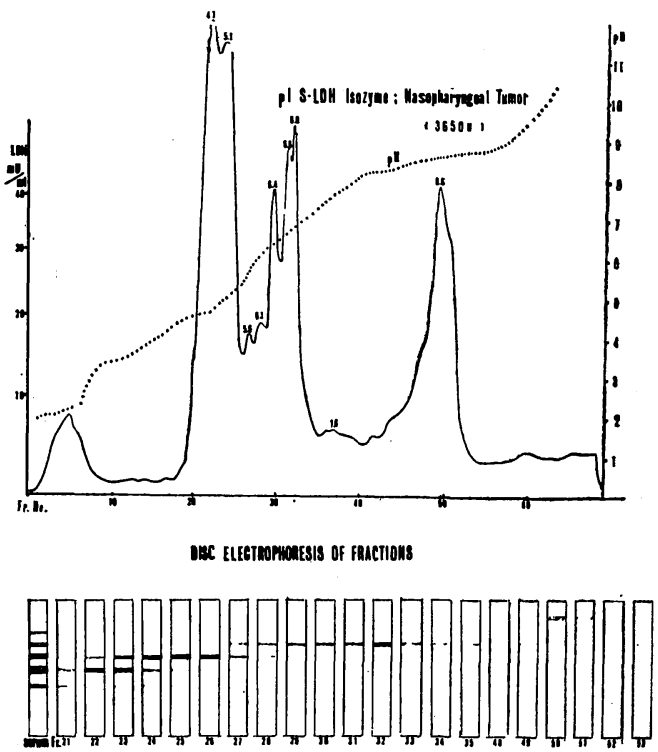

Fig. 4. pI S-LDH isozyme pattern and disc electrophoretic patterns of the corresponding fractions in nasopharyngeal tumor.

して見られる $\mathrm{pH}$ 6.6 6.7 域に出現する活性ピークは GEF であ同様に見いだされるが，正常人血清および非 腫瘍性疾患で $\mathrm{EF}, \mathrm{GEF}$ でともに殆んど認むべきピーク 或いは活性帯として検出されなかった. なお $\mathrm{EF}$ 分画後 溶出液を透析, 濃縮して Disc 電気泳動法により分画し たが pI 6.6 分画はいずれる LDH 4 亿相当する易動度 を示した。

2）脐带血 SLDH の EF, GEF 亿よる分画成績 脐帯血および同一母体血 SLDH につき同様に検索を した 12 例全例に上述の pI 6.6 亿一致する反応帯の出現 をみ，並行して分離を試みた母体血血清には本分画の出 
現は認められなかった．総活性 220 単位および 140 単位 を示した脐帯血 SLDH の EF 分画, GEF 扰上び Disc 電 気泳動後の醳素染色パターンは Fig. 5.〜 7. に示したご

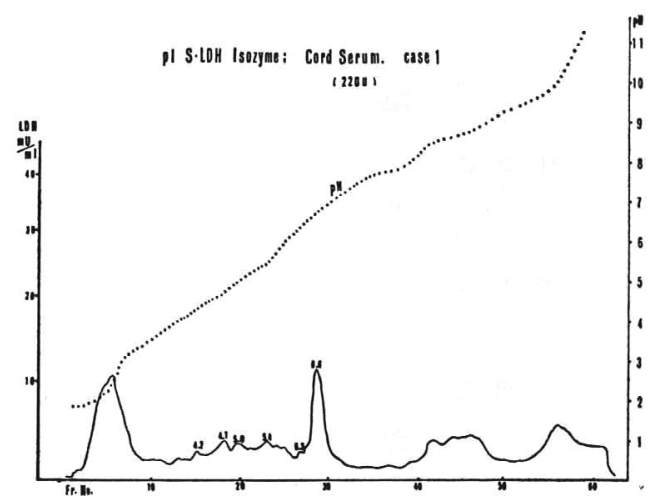

Fig. 5. pI S-LDH isozyme pattern of cord serum, the case $\mathrm{I}$.

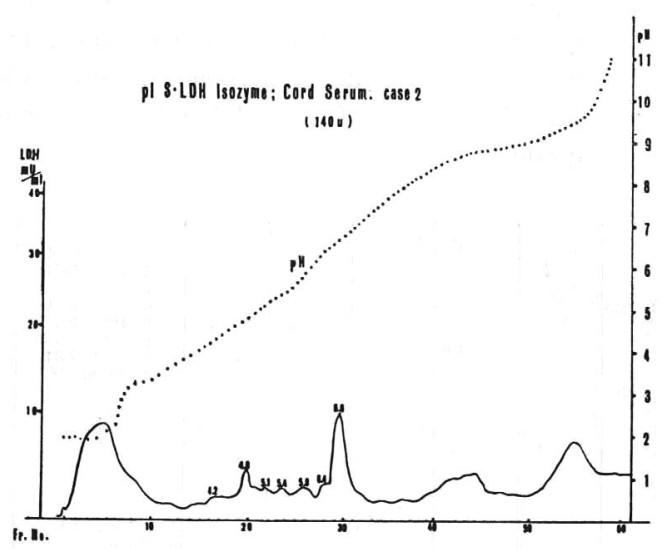

Fig. 6. pI S-LDH isozyme pattern of cord serum, the case II.

\section{Gel-Electrofocusing}
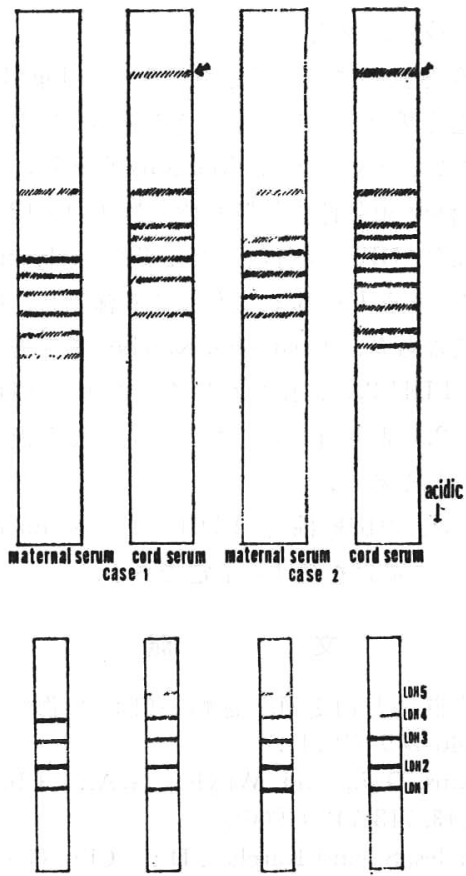

Polyacrylamide Electrophoresis

Fig. 7. Gel electrofocusing (upper) and polyacrylamide gel electrophoresis (lower) of cord serum as compared with the maternal serum.

とくで特に $\mathrm{EF}$ 分画で何れむ $\mathrm{pH} 6.6$ に一致して高い䤃 素活性のピークが見いた゚された。

本分画の由来が胎盤, 胎児組織の何れによるか子は現在 その酵素の特性之共に検索中であるが腫瘍患者血清中に 共通して見いだされる本分画が脐帯血に見いだされたと

TWO DIMENTIONAL ELECTROPHORESIS
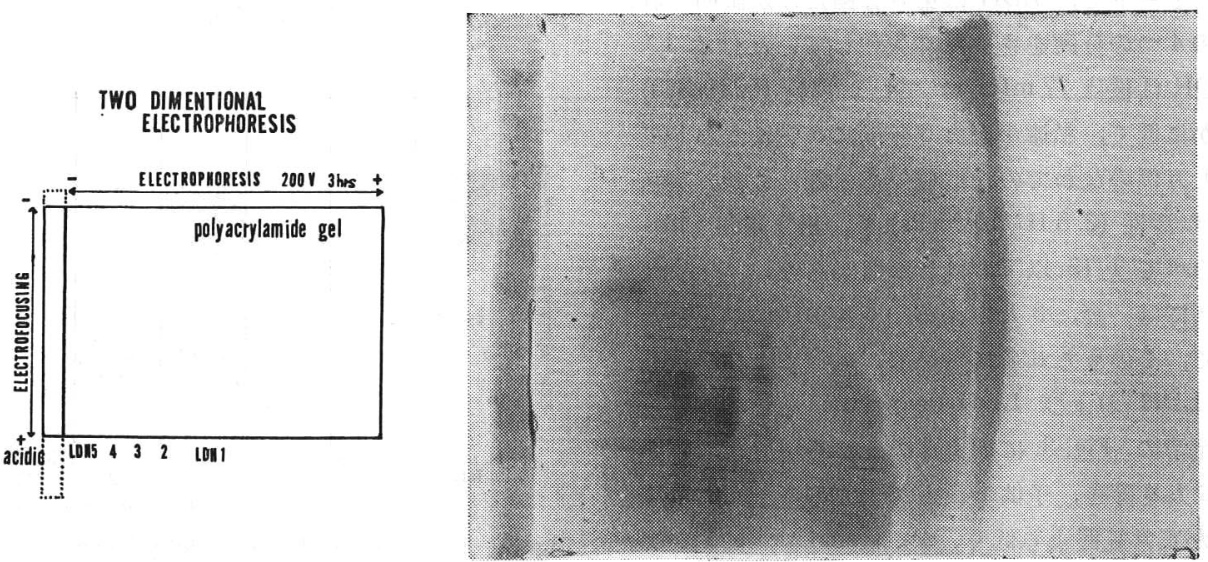

Fig. 8. Two dimensional electrophoresis of serum in breast cancer, 
とは興味梁く詳細は次回に報告したい.

3) 2 次元電気泳動法による GEF, Disc 電気泳動法 分画成績の対比

Disc 電気泳動法により対比を試みたが Fig. 4. の上咽 頭癌のごとく活性の著しく高い例党除いては必らずしも 容易ではない。われわれは Margolis Kenrick らになら い, Gradipore 電気泳動装置を使用し $0.4 \times 12 \mathrm{~cm}$ のガ ラス管により GEF を行なった後平板 polyacrylamide gel の一端におき Fig. 8. の条件により泳動し, 終了後酵 素染色を行なった. Chamoles, Karcher の報告と異なり LDH 1 が LDH 2,3 亿比しむしろやや高い $\mathrm{pH}$ 位に出 現し $\mathrm{LDH} 2,3$ とも $\mathrm{pI}$ の上ではさらに細分画に分㕍す る事実をたしかめた。

SLDH および藏器抽出 LDH 標品の microheterogeneity につき検索を続ける予定である.

\section{文献}

1) 福田守道, 片山吏司, 漆崎一朗：生物物理化学, 15, 246-249 (1971).

2) Hawkins, D.F., and Whyley, G.A.: Clin. Chim. Acta, 13, 713-719 (1966).

3) Chamoles, S., and Karcher, D.: Clin. Chim. Acta, 30, 337-341 (1970).

\section{4. 遺伝性 $\mathrm{H}$ 型乳酸脱水素酵素欠損症} 北村 元仕・飯島 直子・橋本 文子 (虎の門病院・生化学科)

1971 年 1 月, 私達は, 軽い糖尿病をもつ 64 才の男子 の外来患者で, 血清 LDH 活性がさわめて低い症例に遭 遇した. 寒天電気泳動による isoenzyme を調べたとと ろ, との患者の血洘, 唾液, 赤血球, 白血球および血小 板ホモジェネートで, LDH 俤 5 分画だけが証明され, 陽極よりの 4 つの分画をまったく久如していた (Fig. 1.).

血清 $\mathrm{LDH}$ 活性は $77 \mathrm{mIU} / \mathrm{ml}$ で, 正常值 (203 325) よりはるかに低く，私達が過去 5 年間に日常検査として 調べた 10 万例のなかでの最低值であった. また, 赤血 球の LDH 活性 $\left(2.5 \mathrm{IU} / 10^{10} \mathrm{cells}\right)$ あ, 正常範囲 (38 52) にくらべて 1/15 以下の值しかなかった.

との症例には, 妻, 3 人の兄弟, 5 人の子供が生存し ているので, そのうち8名について, 血清および赤血球 溶血液の LDH および $\mathrm{LDH}$ isoenzyme をしらべた.

Fig. 2. 亿血清の, Fig. 3. 亿赤血球のそれらをまとめたが, 妻と兄の 2 人を除き，子供全員と弟 1 人の 6 例において， 1) 活性值が正常範囲より低く，2) isoenzyme において は LDH $1\left(\mathrm{H}_{4}\right)$ および LDH $2\left(\mathrm{H}_{3} \mathrm{M}\right)$ の明らかな減少

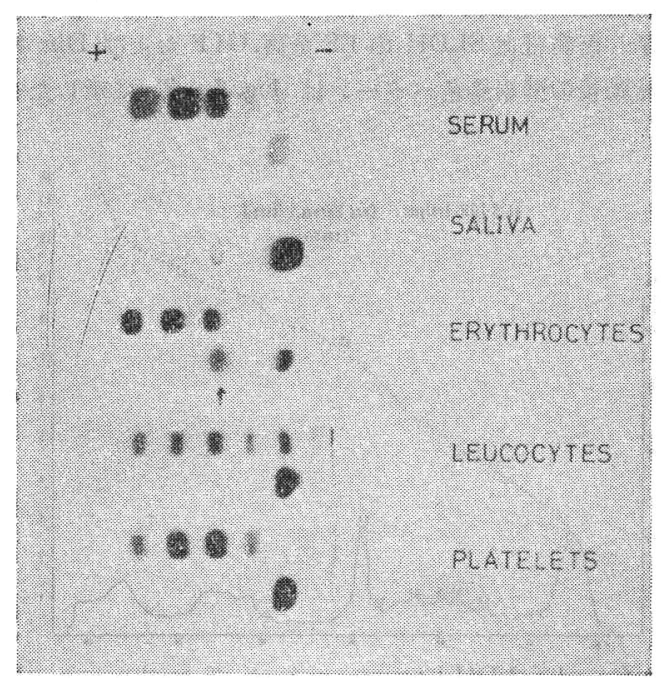

Fig. 1. LDH isoenzyme patterns obtained with agar-gel electrophoresis.

Upper half of the zymogram is that of the specimens obtained from a normal subject for the convenience of comparison. Arrow indicates the position of hemoglobin in the hemolyzate.
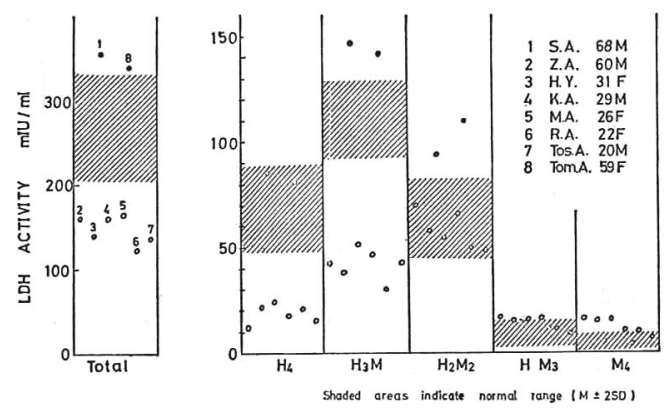

Fig. 2. Serum lactate dehydrogenase isoenzyme pattern of the family members.
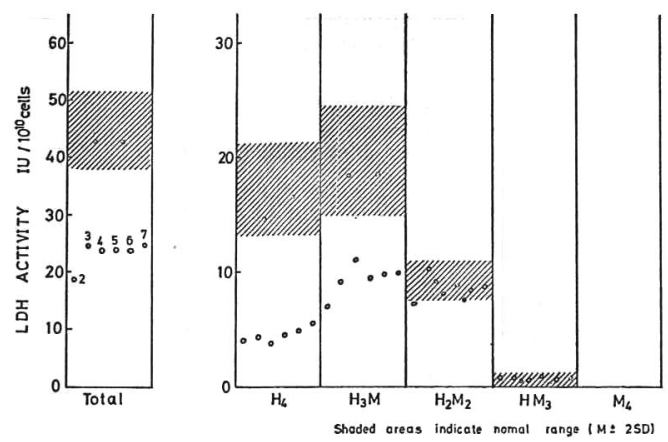

Fig. 3. Erythrocyte lactate dehydrogenase isoenzyme pattern of the family members. 
が観察された。

低活性值を示した 6 人の家族について，LDH のサブ ユニット構成を計算したととろ，Table 1. にまとめた

Table 1. H-Subunit to M-subunit ratio of lactate dehydrogenase in serum and erythrocytes.

Serum

\begin{tabular}{lr|rc}
\hline & $\begin{array}{c}\text { No. of } \\
\text { cases }\end{array}$ & \multicolumn{2}{c}{$\mathrm{H} / \mathrm{M}$} \\
\cline { 3 - 4 } & & mean & range \\
\hline Family members* & 6 & 1.4 & $1.1 \sim 1.6(\min \sim \max )$ \\
Normal subjectes & 108 & 2.5 & $2.0 \sim 3.0( \pm 2 \mathrm{SD})$ \\
\hline
\end{tabular}

Erythrocytes

\begin{tabular}{lr|ll}
\hline Family members* & 6 & 2.2 & $2.0 \sim 2.4(\min \sim \max )$ \\
Normal subjects & 11 & 3.8 & $3.4 \sim 4.3(\quad \mathrm{\prime \prime})$ \\
\hline
\end{tabular}

* 5 childrens and 1 brother possessing low LDH.

ように，血清，赤血球ともに，H/M の比において正常 者の約 $1 / 2$ の值がえられた.

以上の結果から, 本症例の発端者は $\mathrm{H}$ 型 $\mathrm{LDH}$ 久損の ホモ接合体，6人の家族はへテロ接合体であるととが結 論される. 家系図は Fig. 4. のごとくである.

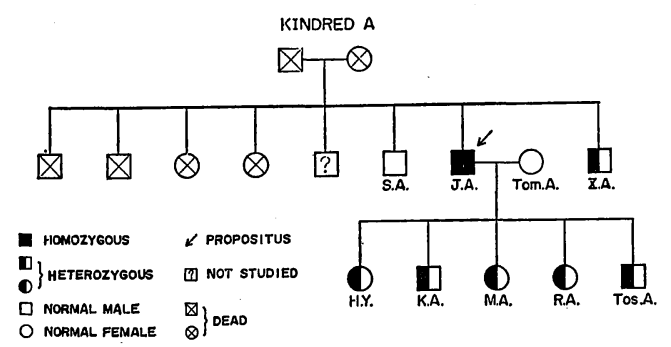

Fig. 4. Hereditary deficiency of H-subunit of lactate dehydrogenase.

（なお，本研究は現在 Clinica Chimica Acta 亿投稿 中である.)

25. 血清 LDH アインザイムの異常パター ンの構成機序とその消長についての研究

$\begin{array}{lrrr}\text { 大平 } & \text { 一郎・荻原 } & \text { 正雄・金子 } & \text { 秀男 } \\ \text { 松岡 } & \text { 継明・寺岡 } & \text { 昭彦・松崎 } & \text { 修二 } \\ \text { 中谷 } & \text { 恒・山口 } & \text { 陽・岸野 } & \text { 健児 } \\ \text { 小林 } & \text { 宏・渡部 } & \text { 忠彦・今泉 } & \text { 忠芳 }\end{array}$

(東京慈恵医大・大平内科)

血清LDH アイソザイムの異常パターンの構成機序は
複雑で，単純に解けるあのではないが，例えば肝炎の患 者では LDH 5 (M 型) が増加する. 又心筋硬塞の患者

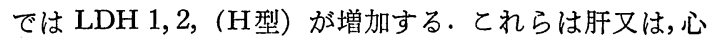
筋より游出されて出て来た事は明らかであるとしてあ, ある時点に血中に放出された LDH 活性が，血中にぞの 位長い時間存在するか，また，その時間は各活性帯で同 一であるか否かと云う点は解っている様で明らかにされ た実験は少ない，また，肺癌患者において S-LDH 3 が 増加するととが多い．然し組織の LDH アイソザイムは LDH 3, 4, 5 が高い值を示している. この様に組織と血 清とでは，相違が見られる。 さらに，我々は多くの SLDH アイソザイムを検索しているうちに，普通に見ら れる 5 本の活性帯の他に色調からして LDH と全く同じ 活性帯を見る事がある。乙の活性帯の成因については殆 んど解っていない. 以上の樣な異常パターンの構成, 消 長などを明らかにする為, 家鬼を用いて種々の形の LDH 負荷実験を行なってみた．家鬼に家鬼製の $\mathrm{M}$ 型 $\mathrm{LDH}$ 結 晶, 約 1 万単位を腹腔内に注入し, 時間的に家鬼血清の $\mathrm{LDH}$ アイソザイムを検索すると LDH 5 が増加し, 平 均 20 時間で元值に復した. また, 家鬼に易動度の異な る牛製の $\mathrm{H}$ 型結晶を同様に 1 万単位注入して観察すると， 牛のH型結晶の易動度の位置に活性帯は現われず，家鬼 のLDH 1 と LDH 2 が増加した. との点は非常に興味 がある。

そして増加した LDH 1,2 が元值に復帰する迄に, 平 均 45 時間かかり, M型結晶注入の場合と約 20 時間以上 の差が見られた。

次に人の肝組織 $5 \mathrm{~g}$ をホモジェナイズし，その上清を 腹腔に注入したが，乙の実験では人の肝の LDH アイソ ザイムの易動度に相当する位置に LDH 5 が現われ, 家 鬼の LDH 5 は増加しなかった. そして, 元值に復帰す る迄の時間は約 18 時閒であった. 家鬼に肺癌組織 $5 \mathrm{~g}$ をホモジェナイズし，その上清を腹腔に注入した実験で は肺癌組織の LDH アイソザイムに相当する位置に LDH 1 5 が現われ，特に $\operatorname{LDH} 3,4,5$ は高い值を示し た. そして LDH 3 は $\mathrm{LDH} 4,5$ よりも消失する迄長時 間かかった。また, 家鬼に, 家鬼肝組織 $5 \mathrm{~g}$ をホモジェ ナイズした上清を腹腔に注入した実験では, 家鬼血清の LDH 2,3,4 が増加し元值に復する迄の時間は約 30 時 間であった. 以上の実験より血中に LDH が増加し, 異 常パターンを形成して元值に復する迄の時間は, H型で は 45 時間前後, M型では約 20 時間前後で, 約 20 時間 以上の差がある事が判った. とれにより S-LDH 3 が肺 癌で增加する例が多い事が解った様な、気がする.

また, 易動度の異なる牛の $\mathrm{LDH}$ 結晶を家鬼に注入し て家鬼の LDH アイソザイムの増加した事, 及び易動度 
の異なる人の肝及び肺癌組織の.上清を家鬼に注入すると， 家鬼の LDH アイソザイムと別に人の LDH アイソザイ ムの易動度の位置にLDH の活性帯が現われると云う事, これらふたつの現象より我々が稀に見た特殊な活性带の 成因は恐らく LDH アイソザイムのサブユニットに特殊 な蛋白，または補醳素が結びついた為に出来た modified LDH アイソザイムと想像された。な书今後の研究によ り多くの事を明らかにしたい。

\section{6. 豚心からのアコニターゼの精製, 第 2 報}

\section{中村正二郎・竹尾 和典 緒方 幍典・清水 二郎}

\author{
（山口大・医・生化学)
}

豚心を細切, 水洗し， 3 倍量の $4 \mathrm{mM}$ クエン酸トリ ス緩衝液 $\mathrm{pH} 7.4$ および $1 / 3$ 量のクロロホルムを加えて ホモジェナイズする，遠心上清に硫安を加え 60〜 75\% 飽和分画を緩衝液で透析し，酵素原液とした。ディスク 泳動により 10 20 個の蛋白分画と 2 個のアコニターゼ 分画(シスアユニチン酸を基質とし,イソクェン酸脱水素 酵素, NADP, NBT で染色) が出現した (Fig. 1.).

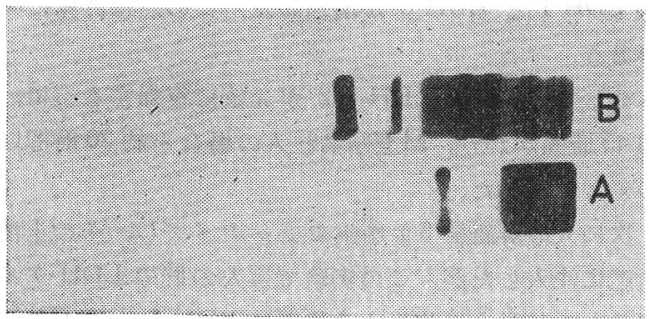

Fig. 1. Disc electrophoretic pattern of the starting material.

B : Amidoblack 10 B staining.

A : Aconitase activity.

The enzyme solution was mixed with $50 \%$ sucrose solution containing thioglycolic acid and layered on the spacer gel. Aconitase activity was stained by the following procedure. Disc gel was incubated in the dark for 60 minutes at $37^{\circ} \mathrm{C}$. in the mixture containing $5.0 \mathrm{ml}$ of $100 \mathrm{mM}$ Tris-HCl buffer at $\mathrm{pH} 7.8,5.0 \mathrm{ml}$ of $1 / 3 \mathrm{M}$ sodium aconitate, $0.5 \mathrm{~m} l$ of $10 \mathrm{mg} / \mathrm{d} l$ isocitrate dehydrogenase, $8 \mathrm{mg}$ of NADP, $0.3 \mathrm{ml}$ of $18 \mathrm{mM} \mathrm{MnCl}_{2}$, $1.0 \mathrm{~m} l$ of $4.2 \mathrm{mg} / \mathrm{ml} \mathrm{NBT}, 0.1 \mathrm{~m} l$ of $2.4 \mathrm{mg} / \mathrm{ml}$ PMS, and $0.55 \mathrm{ml}$ water. The reaction was stopped by $7 \%$ acetic acid.

1. 酵素原液のハイドロキシアパタイト・クロマトの 結果を Fig. 2. に示した. 2 個の蛋白分画が溶出し, い ずれあアコニターゼ活性を示した．活性収量は 41\%，

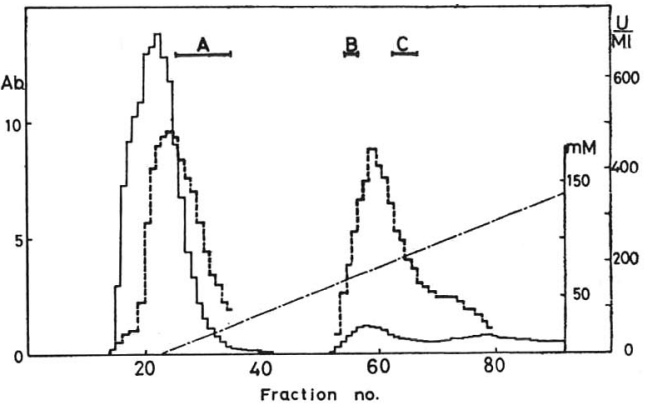

Fig. 2. Chromatogram of aconitase on hydroxyapatite column.

Gulumn : $3.7 \times 19 \mathrm{~cm}$.

Solid line : Optical density at $280 \mathrm{~m} \mu$.

Dotted line : Aconitase activity.

そのうち 52\% は速い分画に，48\% は和そい分画に存在 した. 扰そい分画の比活性は最高点で, 原液の 4.1 倍, 抽出液の 19 倍であった. 両分画をディスク泳動分析す ると, Fig. 3.のように溶出の速い分画はな㹉液に近い

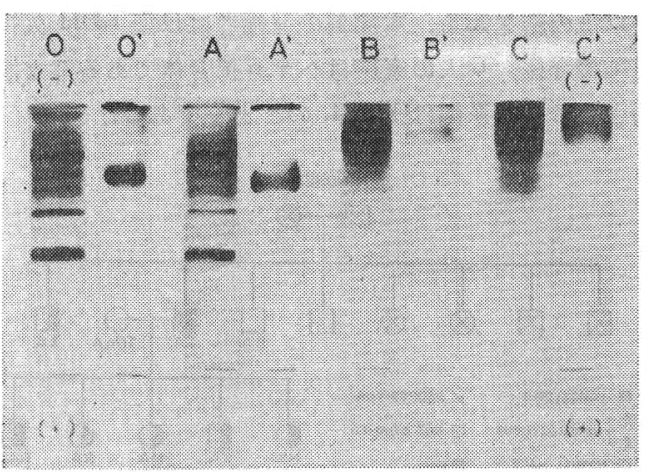

Fig. 3. Disc electrophoretic patterns of the starting material and the fractions on hydroxyapatite column.

$\mathrm{O}$ is the starting material. A, B, and C correspond to the respective fractions in Fig. 2. O, $\mathrm{A}, \mathrm{B}$, and $\mathrm{C}$ are protein stain, and $\mathrm{O}^{\prime}, \mathrm{A}^{\prime}, \mathrm{B}^{\prime}$, and $C^{\prime}$ are aconitase activity.

多くの蛋白分画を含んでいた．アコニターゼ活性は泳動 速度の速い 1 本のバンドを示した．溶出のおそい分画は 原液に比較し, 蛋白分画の数が減少し, 主として速度の おそい分画だけとなっていた.アコニターゼ活性はその 主分画に一致して出現した。

ついでハイドロキシアパタイトの 2 分画を濃縮し，そ れぞれ Sephadex G 200 で再クロマトした. 酵素活性と 蛋白分画はいずれもほぼ単一の峰となって出現し, しか あほほ一致した。しかし，いずれの場合にあブルーデキ 
ストランに対する溶出容量がほぽ等しく，両者は同一分 子量をむつかのように見兄た。

2. そこであらためて醉素原液を DEAE Sephadex A 50 によって分画した. Fig. 4. 亿その結果を示した. 初

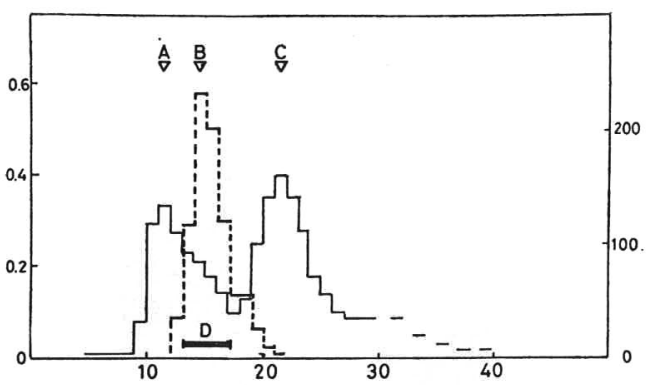

Fig. 4. Chromatogram of aconitase on DEAE Sephadex column.

Solid line : Optical density at $280 \mathrm{~m} \mu$.

Dotted line : Aconitase activity.

期に 2 個の蛋白分画が溶出し，アコニターゼ活性はその 中間に存在した。活性収量は $83 \%$, 比活性は最高の部分 で原液の 25 倍であった (平均 20 倍).アコニターゼ活性 の強い分画を集め，ディスク泳動分析すると，比較的泳 動速度の找そい蛋白分画をふくんでいた.
この DEAE Sephadex 活性分画をさらにハイドロキシ アパタイトで再クロマトした. Fig. 5. にその結果を示し

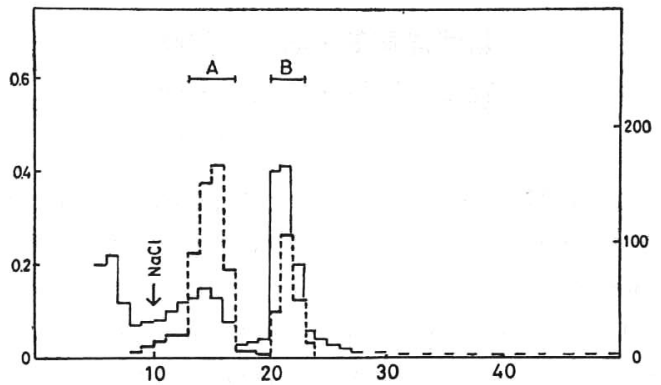

Fig. 5. Chromatogram of active fractions obtained by DEAE-Sephadex chromatography on hydroxyapatite column.

Solid line : Optical density at $280 \mathrm{~m} \mu$.

Dotted line : Aconitase activity.

た. 3 個の蛋白分画が溶出し，その 2 個にほぼ一致して, 2 個のアコニターゼ活性が出現した. ディスク泳動分析 により, 溶出の速いアコニターゼ分画はかなり純粋であ ることがわかった．溶出速度のおそい分画はなおかなり 不純であった。しかしいずれも蛋白分画の泳動速度はお そく類似していた (Fig. 6.).

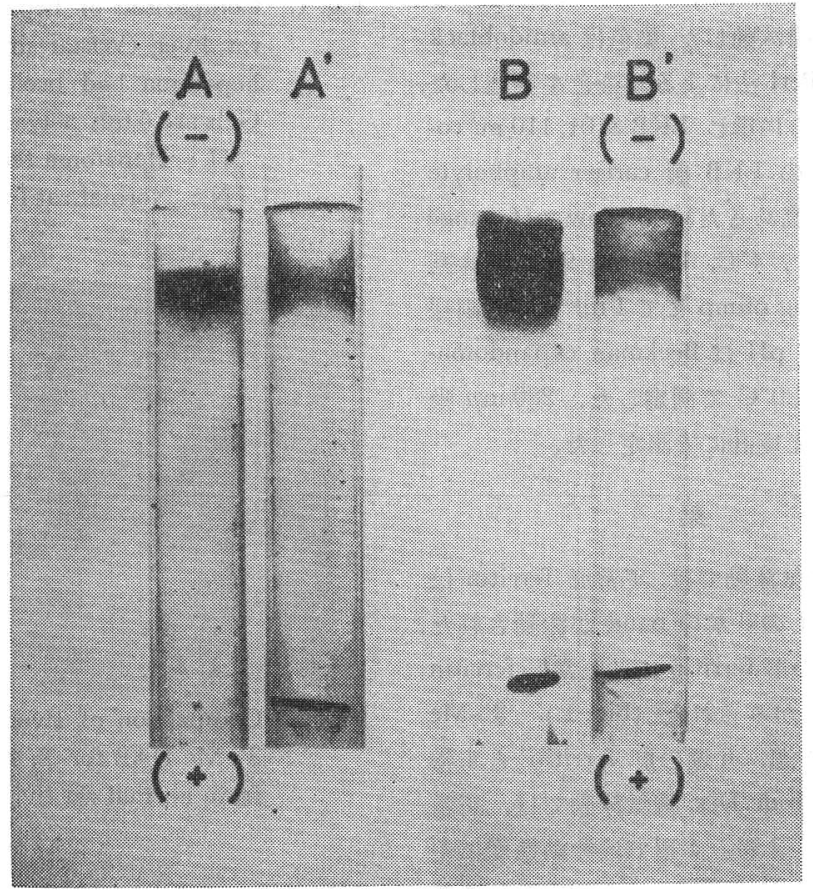

Fig. 6. Disc electrophoretic patterns of active fractions in Fig. 5.

$\mathrm{A}$, and $\mathrm{B}$ correspond to the respective fractions in Fig. 5. A and B are protein stain, and $\mathrm{A}^{\prime}$ and $\mathrm{B}^{\prime}$ are aconitase activity. 


\section{7. $3^{\prime}-M e D A B$ 肝癌の特異 ferritinにつ} いて

$$
\begin{gathered}
\text { 新津洋司郎・石谷 邦彦 } \\
\text { 福田 守道・漆崎 一朗 } \\
\text { （札㹸医大・癌研・内科） }
\end{gathered}
$$

近年 DAB 肝癌発生過程における pyruvate kinase, aldolase の isozyme pattern の特徵的変化および血清中の $\alpha$-fetoglobulin の特異的出現が注目されてきた. 1970 年 Richter らは rat hepatoma に2つの型の ferritin が存在 するととを報じた. 今回我々は DAB 肝癌発生過程にお ける特異的 ferritin の出現を電気泳動上から検討したの で報告する。

\section{材料ならびに方法}

実騃動物は Wistar 系雄 rat 体重 $150 \mathrm{~g}$ 前後を用い, $0.06 \% 3^{\prime}-\mathrm{Me} \mathrm{DAB}$ 食を連日投与し, 飼育開始後 2 週, 4 週, 6 週掞よび 17 週目の肝組織より抽出した ferritin につき検討した. 17 週目の肝組織は形態学的に明らか に肝癌を認めた. 肝 ferritin の精製分離は Drysdale 法 により GM cellulose および Sephadex G 200 column を 用いて実施した. Polyacrylamide Disc 電気泳動は Clark 法に準じて，化学重合した $6.6 \%$ polyacrylamide gel を 用い, $4{ }^{\circ} \mathrm{C}, 200 \mathrm{~V}$ で 3 時間泳動した.染色は amidoblack $10 \mathrm{~B}$ による蛋白染色と Perl 法による鉄染色を実施した. 等電点分画は Svensson らに準じ LKB 8101, $110 \mathrm{ml}$ column を使用, $\mathrm{pH}$ 4 6 6 のKB 製 carrier ampholyte から ferritin の分離能を高めるため narrow $\mathrm{pH}$ range （pH 4.93〜 5. 45）を作製し, $4^{\circ} \mathrm{C}, 1,100 \mathrm{~V}, 96$ 時間泳動 した. 泳動後 proportioning pump にて $1 \mathrm{ml}$ ずつ分画採 取し, 各 fraction につき, $\mathrm{pH}$ は Beckman expandomatic SS-2 pH meter により $20^{\circ} \mathrm{C}$ で測定した。 $280 \mathrm{~m} \mu$ 吸 光度は島津 UV 200 分光光度計にて測定した.

$$
\text { 結果 }
$$

Polyacrylamide Disc 電気泳動では, 正常肝 ferritin は oligomer, dimer, monomer の 3 本の band が泳動された. $3^{\prime}-\mathrm{Me} \mathrm{DAB}$ 投与 17 週目の肝 ferritin には正常肝 ferritin より易動度の速い band がみられた (Fig. 1.). 3'-Me $\mathrm{DAB}$ 連日投与後 2 週, 4 週, 6 週の肝 ferritin と正常 肝 ferritin の polyacrylamide Disc 電気泳動では, 正常 肝 ferritin の所見に比し， 2 週，4週では泳動態度に差 異を認めないが， 6 週目の肝 ferritin では 17 週目のそ れと同様に易動度の速い band を認め得た (Fig. 2.). $3^{\prime}-\mathrm{Me} \mathrm{DAB}$ 投与後 2 週, 4 週, 6 週目の肝組織は形態学

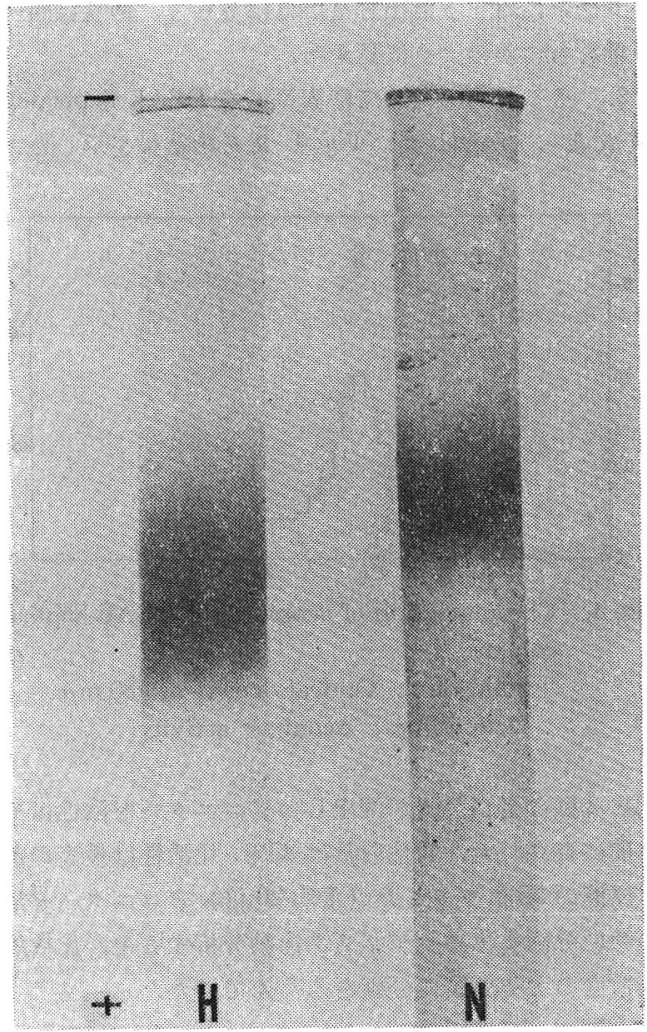

Fig. 1. Comparison of hepatoma ferritin with normal rat liver (Wistar strain) ferritin in which the hepatoma had been induced with $3^{\prime}$-Me DAB. Gels are $6.6 \%$ polyacrylamide.

$\mathrm{H}$ : Hepatoma ferritin.

$\mathrm{N}$ : Normal rat liver ferritin.

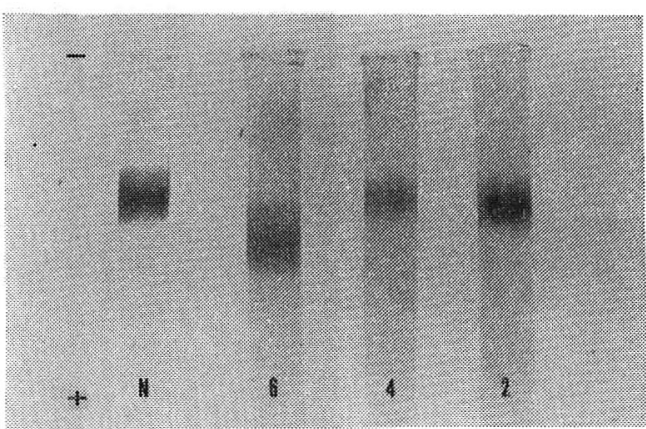

Fig. 2. Comparison of liver ferritin from rats fed with $3^{\prime}-\mathrm{Me} \mathrm{DAB}$ for 2,4 , and 6 weeks with ferritin from normal rat liver $(\mathrm{N})$.

的に肝癌の所見を示さなかった．等電点分画では，正常 肝 ferritin の $\mathrm{pH}$ range は 5.04 から 5.29 であり 2 つの main peak を示した. その各々の $\mathrm{pH}$ は 5.16，5.25 で 
あった (Fig. 3.). 一方 3'-Me DAB 投与 17 週目の肝

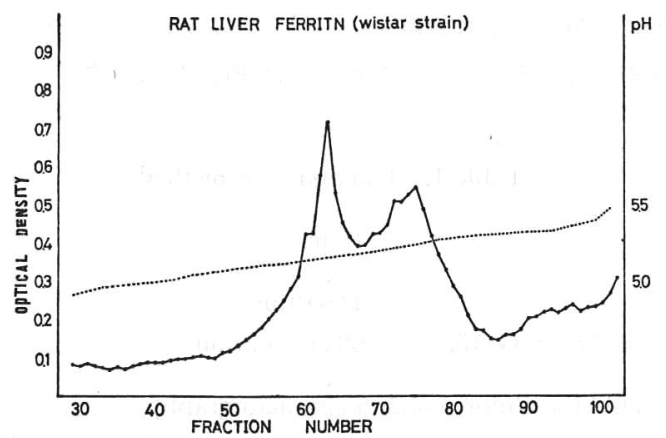

Fig. 3. Isoelectric focusing of normal rat liver ferritin.

ferritin は $\mathrm{pH}$ range 4.96 から 5.30 と, 明らかに正常肝 ferritin に比し酸性域の桩大が認められた. Main peak は 3 つから成り, その各々の $\mathrm{pH}$ は 5. 03, 5.16, 5.25 であ り中性側の 2 つの peak の $\mathrm{pH}$ は, 実験誤差 $\mathrm{pH} \pm 0.02$ を考慮に入れても，正常肝 ferritinのそれと良く一致し た (Fig. 4.). 従って酸性側の $\mathrm{pH} 5.03$ を主峯とする

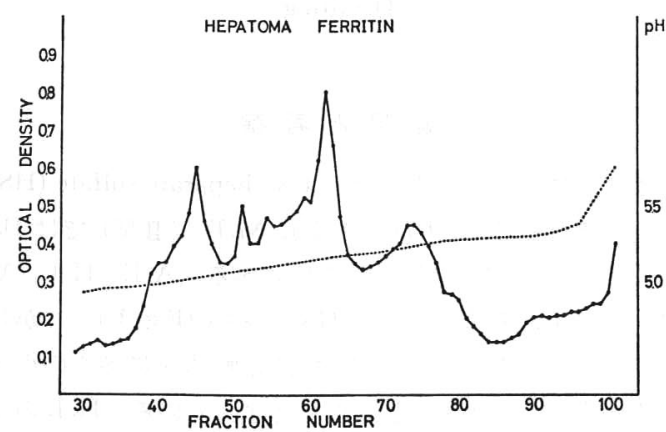

Fig. 4. Isoelectric focusing of hepatoma ferritin in which the hepatoma had been induced with $3^{\prime}-\mathrm{Me} \mathrm{DAB}$.

$2 \sim 3$ 本の peak 群は $3^{\prime}-\mathrm{Me} \mathrm{DAB}$ 肝癌に特異的な ferritinであると思われた．等電点分画により得た各 main peak につき polyacrylamide Disc 電気泳動を実施した (Fig. 5., 6.). 3'-Me DAB 投与 17 週目の肝 ferritin では, 特異的と思われる最む酸性側の peak が Disc 電気泳動 上最も速い易動度を示した (Fig. 5.). すなわち polyacrylamide Disc 電気泳動上 $3^{\prime}-\mathrm{Me}$ DAB 肝癌飞特異的 と考えられた易動度の速い ferritin は, 等電点分画上, 正 常肝 ferritin に認められない, より酸性側の peak を示 す ferritin であることを示している. Higgins \& Anderson 法による再生肝 ferritin の polyacrylamide Disc 電気泳動では, その泳動態度に差はなかった。

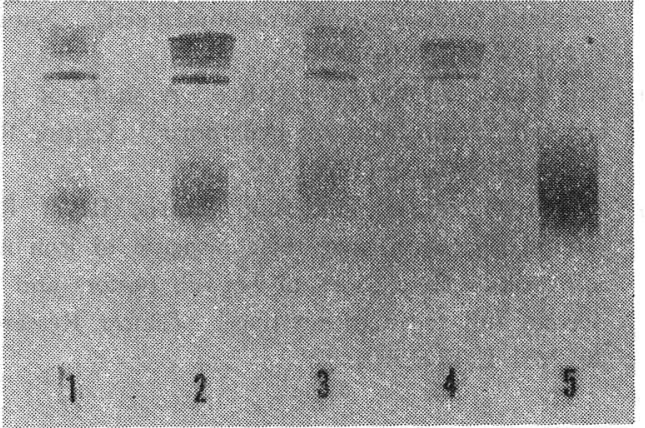

Fig. 5. Disc electrophoretic pattern of the fractions obtained by isoelectric focusing of hepatoma ferritin.

1: Tumor specific fraction (most acidic).

5: Unfractionated hepatoma ferritin.

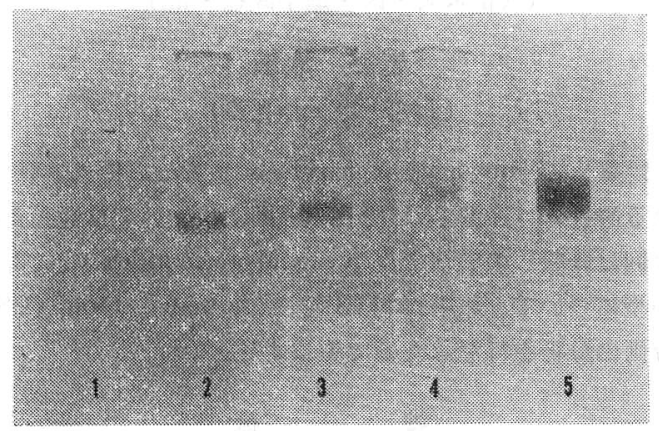

Fig. 6. Disc electrophoretic pattern of the fractions obtained by isoelectric focusing of normal rat liver ferritin.

1: Most acidic fraction corresponding to tumor specific ferritin.

5: Unfractionated normal rat liver ferritin.

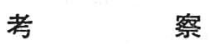

すでに 1961 年 Richter らは HeLa cell, KB cell など 人由来の neoplastic cell line につき正常細胞と Disc 電 気泳動上態度を異にする ferritin の存在を予報し，1970 年彼は Novikoff ascites tumor, Reuber H-35, H-139 お よび Morris 5123 hepatoma, p-DAB 肝癌に拈いて faster moving ferritin を証明した。

今回我々は $3^{\prime}-\mathrm{Me} \mathrm{DAB}$ 肝癌発生過程に拈いて polyacrylamide Disc 電気泳動上易動度の速い ferritin をみと め，それが等電点分画上正常肝 ferritin には認められな いより酸性の等電点をあった ferritin であるととを明ら かにした。

文献

1) Richter, G.W.: Comparison of ferritin from 
neoplastic and non-neoplastic human cells. Nature 7, 207, 616-618 (1965).

2) Richter, G.W. \& Lee, J.C.K.: A study of two types of ferritin from rat hepatomas. Cancer Research 30, 880-888 (1970).

3) Linder, M., Munro, H.N., and Morris, H.P.: Rat ferritin isoproteins and their response to iron administration in a series of hepatic tumors and in normal and regenerating liver. Cancer Research 30, 2231-2239 (1970).

\section{Mucopolysaccharidosis 患者の尿中 酸性ムコ多糖の性状}

\section{田中 幸男・高園 磯子}

(久留米大・医・進学課程・化学)

\section{岩谷 泳珀}

(九大・医・小児科)

既報 ${ }^{1)}$ で mucopolysaccharidosis 患者の尿中に排泄さ れる酸性ムコ多糖 (AMPS) の分画法について検討した. 今回は既報 ${ }^{1)}$ の方法で, mucopolysaccharidosis の 2,3 の型について，尿中 AMPS 特に dermatan sulfate (DS) 分画の分析を行なったので報告する．

\section{検体}

実験に使用した尿は，I.D. (mucopolysaccharidosis I 型または Hurler 型)，M.D.（同型または Hunter 型), H.I., A.K.（同 V 型または Scheie 型）から採取し た. 尿は採取後チモールを加え, 直ちに $-20^{\circ} \mathrm{C}$ に凍結 して保存した。患者尿はその AMPS 含量によって 2 な いし $4 l$ を使用した。また対照として患者とほぼ同年龄 の正常児尿 $16 l$ を使用した.

\section{実 験 方 法}

尿中 AMPS の分画法は Table 1.の方法によった．前 報1) と操作の上で異なっているのは，活性炭による尿の 脱色を行なわなかった点である. 構成成分の分析 ${ }^{2)}$ はウ ロン酸はカルバゾール，オルシノールの両法で測定し，

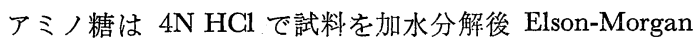
法就よびアミノ酸自動分析機で測定し，硫酸基は Dodgson 法 $^{3)}$ で定量した。 DS 中に含まれているぺプチドは $6 \mathrm{~N} \mathrm{HCl}$ で 20 時間加水分解後, 日立アミノ酸自動分析 機で定量し, 中性糖は $1 \mathrm{~N} \mathrm{H}_{2} \mathrm{SO}_{4}$ で 8 時間加水分解後, TFA 化し，ガスクロマトグラフ法で定量した。 このほ か分子量を Spinco の分析用超遠心機を用いて測定し， また旋光度, 赤外吸収む併わせて測定した.これらの諸測
定值は Table 2. および 3. 亿示す.

多糖鎖の構造を知る目的で chondroitinase (CSase) $\mathrm{ABC}, \mathrm{AC}$ による分解とそのペーパークロマトグラフィ ーを行なった. クロマトグラムは Fig. 2. に示す.

Table 1. Fractionation method.

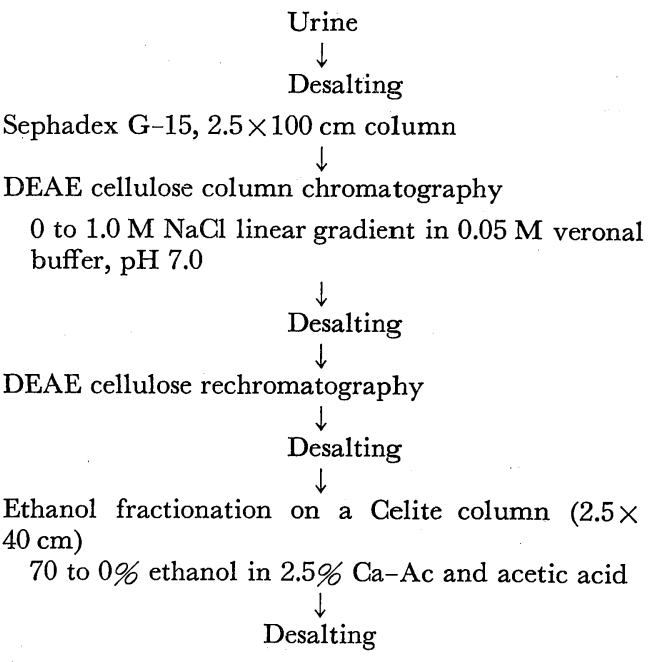

\section{結 果 と考 察}

本実験に用いた患者尿は，DS，heparan sulfate (HS) を含む例であるが，I.D. ( I 型)，M.D. (II 型)では DS が主成分で，HS は極めて少量である.A.K., H.I.（V 型）ではI，II型に比べて HS が多い (Fig. 1.) しかし 同じ V型相互間であ，H.I. では分画 2,3 に多くの小ピ 一クが存在し，A.K. こはやや異なっている. H.I. の分 画 2,3 中にはHS のほかに hyaluronic acid ゃ DS, CS の分解物が混在するととが雪気泳動的分析結果から認め られた。

分析に使用した分画は何れも $\mathrm{G} / \mathrm{O}$ 值, 電気泳動の移 動距離，赤外吸収，旋光度， CS-ase に対する性質等が ブタ皮膚から抽出した DS とほぼ一致する分画である. しかし G/O 值は MD-43 を除いてブタ皮膚 DS よりや や高く， CS-ase ABG による分解でアミノ糖の 6 位に硫

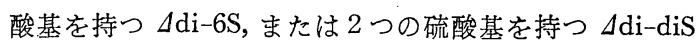
と思われるものが多く, 組織中の DSよりさらに複雑な hybrid 構造を持つむのと思われる (Fig. 2.).

AMPS と蛋白の接合部は下式，すなわち，

$$
(\mathrm{Hex}-\mathrm{N})-(\mathrm{Hex}-\mathrm{UA})-(\mathrm{Gal})-(\mathrm{Gal})-(\mathrm{Xyl})-(\mathrm{S} \text { ' }
$$

のような結合を持つととが明らかにされている，中性糖 分析の結果からは，Xyl 1 モルに対し，Gal 2 モルに近 


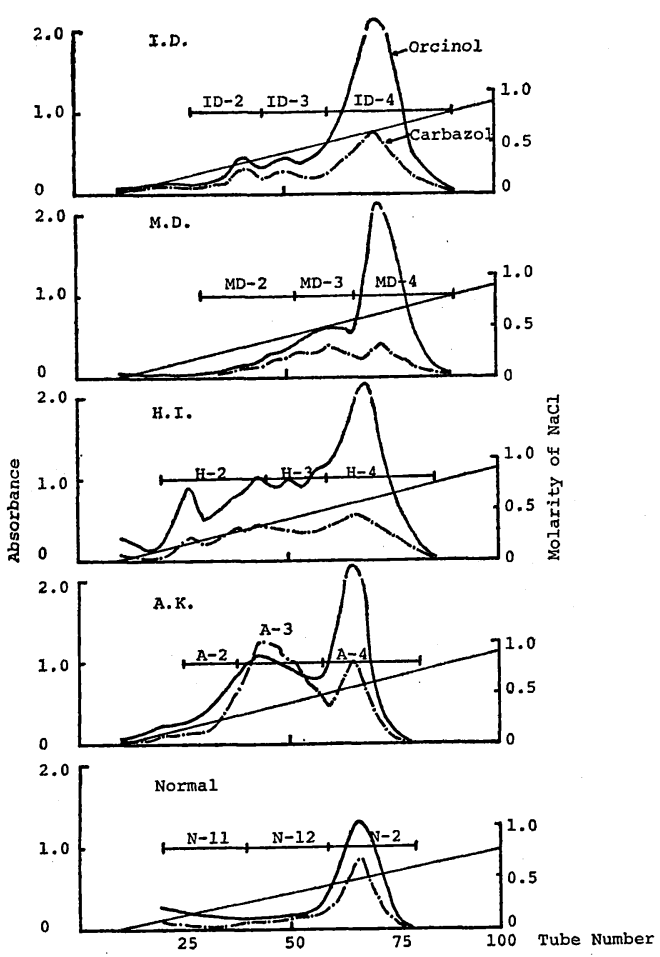

Fig. 1. DEAE cellulose column chromatography of urine.

い值を示し，Gal-Gal 閒あるいは Gal-Xyl 閒で切断さ れたものは少ないと思われるが，ID-44 では Gal/Xyl 比が 1.7 と低く，また A-42 では 2.5 と高く，無視で きない異常を示した．さらに Xyl はエーテル結合で蛋 白部の Ser と結合している. この Ser は, Xyl の 1 モ ルに対し，A-42 では 1.10 とほぼ 1 ： 1 の比を示し， ブタ皮膚のそれに近い值を得たが，他は何れす $0.22 \sim$ 0.68 と低值を示した. とのととから患者尿中の DS に は多糖部の Xyl と蛋白部の Ser の閒から切断され, 末
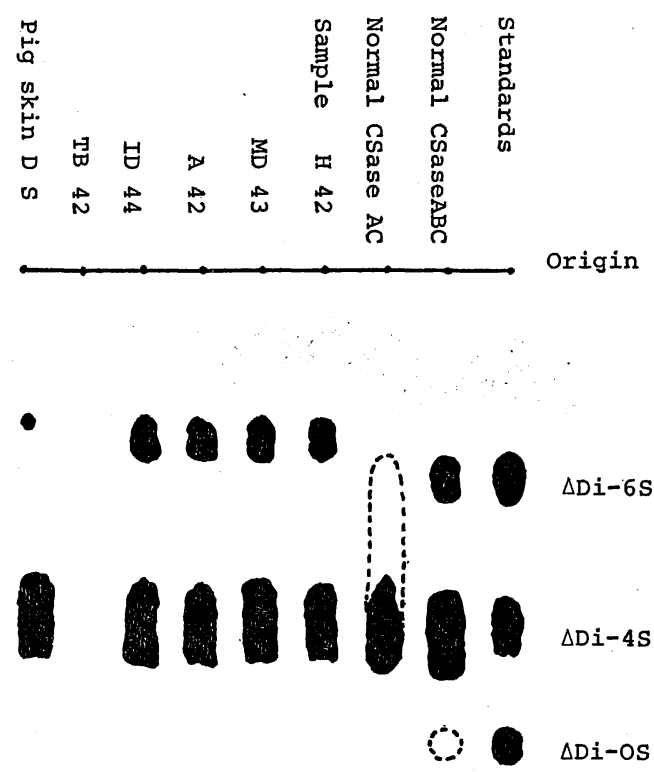

Fig. 2. Paper chromatography of disaccharides obtained by digestion of urinary $\mathrm{DS}$ with chondroitinase ABC.

端に全くアミノ酸を含まないものがかなり存在するすの と考えられる。

次に多糖鎖と結合した Ser 周辺のペプチドについて考 察すると，DS 中に含まれるアミノ酸では各例とも Ser が他のアミノ酸に比べて高く， Gly がこれに次いでい る. Ser と Gly の比は症例によってまちまちで，ID-44 で 2.2:1, MD-43 で $10.7: 1, \mathrm{~A}-42$ で $6.5: 1$ であるが H-42 では 1 ： 1 であった. Ser に隣接するアミノ酸は 恐らくGlyであり，H-42 のように Ser-Gly 結合がほ ぼ完全に残っているもの，MD-43 のように多糖末端は Ser だけを残し他のほとんどすべてのアミノ酸が切断さ れているもの，括よびその中閒的な型を取るものなどさ まざまであった．患者尿中のアミノ酸と正常尿のそれと

Table 2. Analyses of DS isolated from urine and pig skin (CS-A/C fraction was used for analysis in normal urine.)

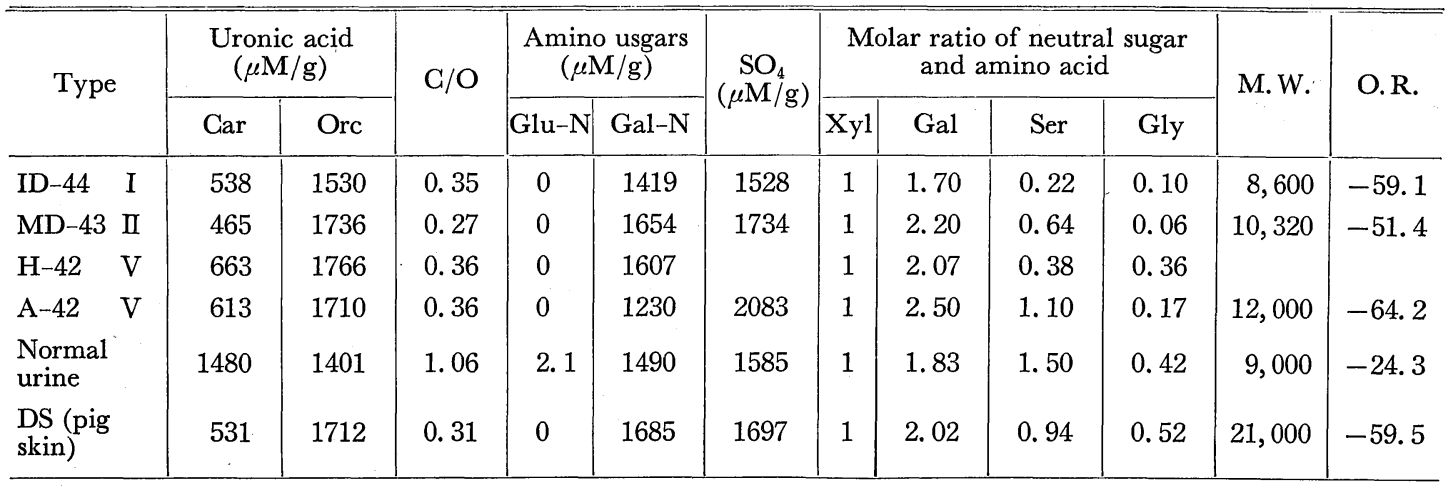


（128）生物物理化学

Table 3. Amino acid analyses of DS isolated from patients and CS-A/C from normal child. All results are expressed as $\mu$ Moles of amino acid per $100 \mu$ Moles of Gal-N.

\begin{tabular}{l|l|l|l|l|l}
\hline \hline Amino Acid & ID-44 & MD-43 & H-42 & A-42 & Normal \\
\hline Asp & trace & 0.04 & 0 & 0 & 0.15 \\
Thr & 0 & trace & 0 & 0 & 0.06 \\
Ser & 0.21 & 0.82 & 0.88 & 1.12 & 0.47 \\
Glu & trace & 0.02 & 0.11 & trace & 0.08 \\
Gly & 0.10 & 0.07 & 0.83 & 0.17 & 0.17 \\
Ala & 0 & trace & 0.14 & trace & 0.07 \\
Val & 0 & 0 & 0 & 0 & 0.04 \\
Ile & 0 & 0 & 0 & 0 & 0.07 \\
Leu & 0 & 0 & 0 & 0 & 0.09 \\
Lys & 0 & trace & 0 & 0 & 0 \\
Arg & 0 & 0 & 0 & 0 & 0 \\
Glu-N & 0 & 0 & 0 & 0 & 0.17 \\
\hline
\end{tabular}

を比較すると,患者尿中アミノ酸が Ser, Gly のほか Glu， Ala のほほ 4 種以内に限られているのに対し，正常尿で は Ser, Gly が高值を示すととは患者の場合に類似して いるものの，その他 7 ～ 8 種のアミノ酸が認められた. とのととから，正常尿では，糖鎖と結合しているぺプチ ドが，患者のそれと比較して大きいと結論できよう．と の尿中 AMPS 中に含まれているアミノ酸 pattern の差 違が患者と正常児の閒に見られる最も著明な特色であっ た.

尿中 AMPS の平均分子量は, 患者の DS で 8,600 12,000 であり，正常児で 9,000 であって，両者間に有 意の差があるとは考えられず，またとの值は，ブタ皮膚 加抽出した DS の分子量 21,000 の約 $1 / 2$ 亿当ってい る.

\section{参 考 文 献}

1）田中幸男, 小倉藤代, 岩谷泳珀：生物物理化学, 15, 219 (1971).

2) Tanaka, Y. and Gore, I.: J. Chromatog., 23, 254 (1966).

3) Dodgson, K.S.: Biochem. J., 78, 312 (1961).

\section{9. 肝疾患時における血清糖蛋白の变動に دいて}

\author{
金田 春雄・高橋 勇夫 \\ 藤田 実彦・後藤 利昭 \\ (日大・医・第 3 内科)
}

\section{河合 忠・松田 重三 \\ （日大・医・臨床病理学）}

血液及び体液中におけるアミノ糖やへキンースを含有 する高分子の物質に関する生物物理化学的研究に関して は，従来多くの報告がなされている，特に臨床に抽い ては炎症性疾患及び悪性腫瘍をめぐって酸性ムコ多糖体 及び蛋白結合糖質（糖蛋白）に関する知見が急速に解明 されつつある。我々も従来悪性腫瘍疾患江関連する糖蛋 白をその含有する各糖質成分とあわせ測定し，本症の補 助診断と治療経過の観察の上に有益な検査法の 1 つであ る事を本学会に执いて報告して来た. 一方, 従来より生 体内に拈ける糖蛋白の変動に関し，その起源をめぐって 種々論議されているが，Welner, Spiro, Shetlar，等より 血清糖蛋白の生合成に関し, 肝が大きな代謝活動を有し ている事実は否定し得ない，一方，従来より急性肝炎の 大多数は予後良好にて比較的速やかに治癒改善を示すが, 時に急性或いは亜急性の経過にて組織学的飞激しい実質 障害を伴い急速に死に至る予後不良の 1 群がある事は周 知の如くである．との両型の予後判定として従来の諸検 查法においては尚多くの問題を残している.とれらの点 から肝機能と密な関連を有す糖蛋白を実質障害の最む著 しい急性重症肝炎例につき測定し，対照とせる慢性肝炎 20 例, 肝硬変症 30 例と比較検討し, 2,3 の結果を得た ので報告した。

\section{0. 蛋白分画，免疫グロブリンと膠質反応}

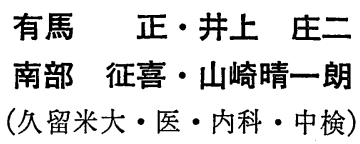

肝疾患における $r$-glob と膠質反応の相関については 古くから云われてきているが, 血清蛋白成分の変化にも とづく諸因子と関連があり，種々の膠質反応と蛋白分画 との間には多少の相違が認められている．私共は本大学 附属病院中検に提出された 140 例の患者血清について膠 質反応として CCLF, TTT, $\mathrm{CoCl}_{2}, \mathrm{ZTT}$, 高田反応と蛋 白分画との相関を検討し，血清膠質反応の本態を更に研 究するため, Hyland 社の Immunoplate を用いて定量 
した免疫 glob, IgG, IgA, IgM との関倸について追求し た. 又とのうち臨床的あるいは生榆的に誩断の確定した 急性肝炎 5 例, 慢性肝炎 7 例, 肝硬変症 8 例, 原発性肝 癌 5 例, 転移性肝癌 2 例をえらび免疫 glob 己膠質反応 との関倸についてへパトグラムを作製し検討した。まず 血清翏質反応之血清 glob 分画との関倸については, 各 膠質反応のうち $\gamma$-glob と良い相関を示すすのは ZTT, TTT で相関係数は各々 $0.89,0.77$ といずれあ良好な相 関を認めたが CCLF, $\mathrm{CoCl}_{2}$, 高田反応は各陽性度の平均 值とは良好な相関関係を示すが，全例についてはばらつ きが多く, ZTT, TTT に比べ低い相関関倸を示した. 一方 $\gamma$ 以外の glob 分画之膠質反応の関係については $\mathrm{CoCl}_{2}$ 反応が $\alpha_{2}$-glob と相関係数 -0.50 で比較的良好 な逆相関を示し $\mathrm{CoCl}_{2}$ 反応が左方に移動した場合, $\alpha_{2}$-glob が増加する例が多いが，他の膠質反応と $\alpha_{1^{-}}$, $\alpha_{2^{-}}, \beta-$ glob との相関性については殆んど認められなか った.

血清膠質反応と免疫 glob との関係については Table 1. に示すごとく， CCLF は， IgG, IgM と軽度相関を

Table 1. Relationship between serum colloid reactions and immunoglobulins.

\begin{tabular}{l|l|l|l}
\hline \hline & IgG & IgA & IgM \\
\hline CCLF & 0.50 & 0.25 & 0.55 \\
TTT & 0.60 & 0.24 & 0.41 \\
$\mathrm{CoCi}_{2}$ & 0.53 & 0.14 & 0.42 \\
Takata & 0.61 & 0.44 & 0.37 \\
ZTT & 0.76 & 0.41 & 0.48
\end{tabular}

Figures are correlation coefficients.

示すが IgM との相関がつよく，TTT, $\mathrm{CoCl}_{2}, \mathrm{ZTT}$, 高田反応は IgG との相関がつよかった. とくに ZTT と IgG との相関は著明で相関係数 0.76 を示した. IgA との関係はZTT, 高田反応で軽度の相関が認められたが, その他の膠質反応との相関性は低かった，IgM とは CCLF 以外飞 TTT, $\mathrm{CoCl}_{2}, \mathrm{ZTT}$ で柽度であるが有意の 相関傾向を認めた.

各種肝疾患における血清膠質反応と免疫 glob との関 係を平均値で Fig. 1. 亿示したが，急性肝炎では各膠質 反応はわずかに陽性化するが，正常範囲にあり，免疫 glob IgM で軽度の増加が認められた他は IgG, IgA は正常であつた。慢性肝炎では免疫 glob は IgG 亿軽度 の増加を認めた例ああったが，急性肝炎の場合之同様の 傾向を示し有意差は認められなかった. しかし膠質反応 では軽度の異常を示すむのが多くみられた，肝硬変では

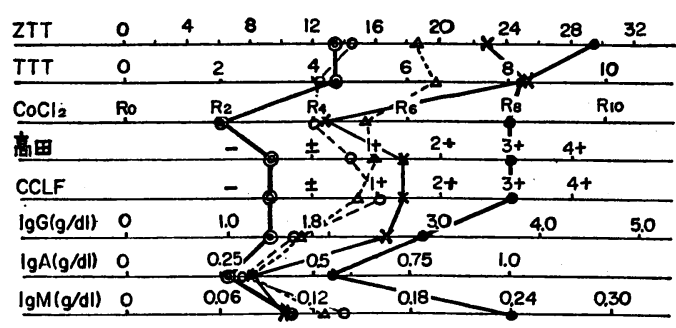

Fig. 1. Relationship between serum colloid reaction and immunoglobulins in various kinds of liver diseases.

Acute hepatitis (5) $\times$ Hepatoma (5)

$\triangle$ Chronic hepatitis (7) (O) Metastatic liver cancer (2)

- Cirrhosis of liver (8)

ZTT, TTT，高田，CCLF は著明な異常を示し， $\mathrm{CoCl}_{2}$ 反応は $\mathrm{R}_{8}$ と右方に移動し，免疫 glob では IgG, IgA, IgM いずれの分画でも増加を認めたが，肝硬変を基礎 として発生した肝癌では $\mathrm{CoCl}_{2}$ 反応は左方に移動し $\mathrm{R}_{4}$ と正常範囲にあり, 免疫 glob みで IgA, IgM 分画は正常であった. 転移性肝癌では $\mathrm{CoCl}_{2}$ 反応は更に左方に移動し, ZTT, TTT が軽度増 加する他は免疫 glob 分画についてもすべて正常であっ た.本へパトグラムにトランスアミナーゼ， BSP, Al-P な ぞを組合わせれば更に各肝疾患の鑑別に有用になるかも しれない.

\section{1. 薄層ゲル沪過法による血清蛋白分画法 の臨床的応用，第 9 報. 悪性腫瘍}

\section{青木 紀生・古田 格・松田 重三 山田 秀雄・河合 忠}

（日大・医・臨床病理学）

\section{山岸 安子・大島壽美子 \\ （日大病院・中検）}

Sephadex G-200 Superfine を用いた薄層ゲル汇過法 による血清蛋白分画法にて, 悪性腫瘍の患者の血清につ いて検討したので報告する.

\section{検査材料および測定方法}

検体は悪性腫湯患者 89 例の血清で，その内訳は白血 病 19 例, 悪性リンパ腫 14 例, 癌腫 56 例である. 血清 は原則として治療前のものを使用したが, 加療後の血清 あ 1 部含まれている.

薄層ゲル沪過分画法ならびに定量法については, 以前 にくわしく報告した ${ }^{1)}$. 
成

績

覀性腫湯患者血清についての薄層ゲル沪過分画像の典 型は, $\mathrm{A}$ 分画の減少, $\mathrm{G}$ 分画就よびM分画の増加で, 時 に $\mathrm{G}^{\prime}$ 分画の出現がみられる。とれを免疫学的にしらべ ると，A分画の減少は主に alb と Tf の減少によるが, $\mathrm{A}$ 分画位にみられる $\alpha_{1}$ - 抗トリプシンはむしろ増加して いる. G 分画の増加は IgG の増加により, またM分画 の増加は $\alpha_{2}$-マクログロブリンおよび IgM の増加によ る. な扮明膫な $\mathrm{G}^{\prime}$ 分画の出現は, IgA の増加による ためで, 白血病では 1 例もみられないが, 悪性リンパ腫 では 2 例, 癌腫では 23 例にみられた。

悪性腫瘍を大きく, 白血病, 悪性リンパ腫, 癌腫に分 けて各分画值をみると (Fig. 1.), 全体に総蛋白量は減少

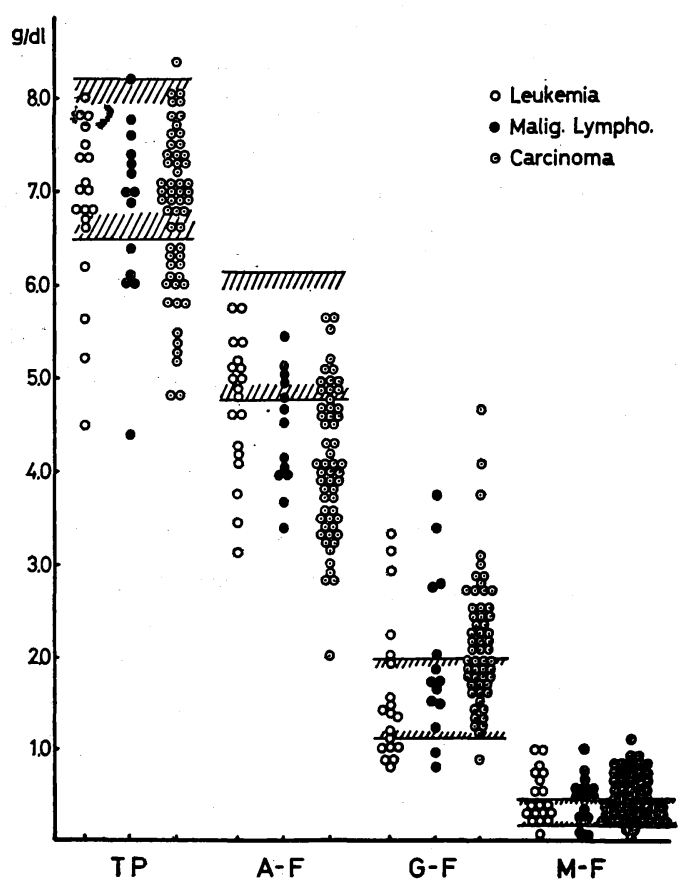

Fig. 1. Serum protein fractionation in various malignancies by using the thin-layer gel filtration technique.

傾向を示し, A 分画值は減少, G分画值およびM分画值は 増加を示す症例が目立つ. 特に総蛋白量およびA分画の 減少は悪性リンパ腫および癌腫で目立ち, G分画の増加 は癌腫および悪性リンパ腫に多いが, 白血病では反対に 減少傾向を示す症例む可成りみられる，またM分画值は 白血病と癌腫の約半数例および悪性リンパ腫の 3 分の 2 の症例に増加がみられる。
各悪性腫湯を更に分類して検討してみると, 白血病で は Fig. 2. に示す如く，急性骨髄性白血病 (AML) では

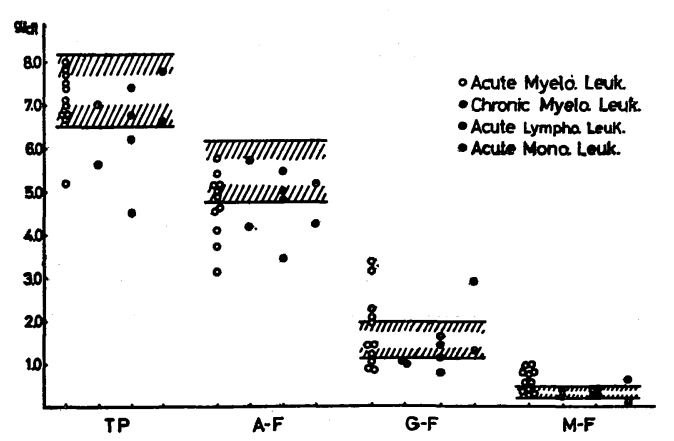

Fig. 2. Serum protein fractionation in leukemia by using the thin-layer gel filtration technique.

総蛋白量がほとんど正常值内であるが，A分画值の減少 が可成り目立ち，G分画值む 1 部減少を示すが,むしろ増 加を示す症例が目立ち, 可成り著明な高值を示すすのす ある.またM分画値も明らかに増加を示す症例が多い. 慢性骨髄性白血病 (CML) 扤よび急性リンパ性白血病 (ALL) は症例数が少ないが総蛋白量とA分画值, G分 画值はいずれも減少傾向を示し，またM分画值はいずれ あ正常值内である.急性単球性白血病 (AMoL) では総 蛋白量には著変がないが, A分画值は減少し, G分画值は 可成り高值となる症例がある。 またM分画值には一定の 傾向はない。

Fig. 3. は悪性リンパ腫について示したもので，ホジキ

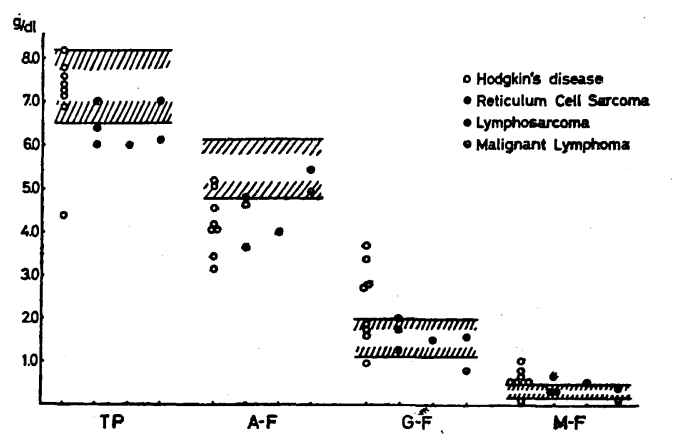

Fig. 3. Serum protein fractionation in malignant lymphoma by using. the thin-layer gel filtration technique.

ン病では末期例の 1 例が総蛋白量の著減を示す以外は全 例が総蛋白量は正常值内である. しかし A 分画值はほと んぞが減少を示し, $\mathrm{G}$ 分画值は半数例は増加傾向を, 半 数例は減少傾向を示し, 一定の傾向はみられない. しか しM分画值はほとんどが高值となる，細網肉腫およびリ 
ンパ肉腫では総蛋白量およびA分画值の減少がほとんど の症例でみられるが，G分画值は全例が正常值内を示し， M分画值は半数例が増加傾向を示す.

癌腫を発生部位別にみると Fig. 4.で，どの部位原発の

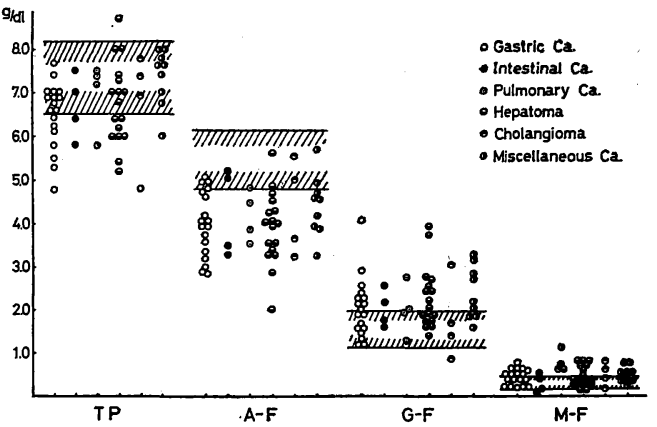

Fig. 4. Serum protein fractionation in various carcinomas by using the thin-layer gel filtration technique.

癌腫においても総蛋白量および $\mathrm{A}$ 分画値の減少, $\mathrm{G}$ 分画 值およびM分画值の増加がみられる，その傾向はなかで あへパトーマで強く, 特に $\mathrm{A}$ 分画值の減少および $\mathrm{G}$ 分画 值の増加が目立つ．ついで胃癌および結腸癌でその傾向 が強い。また肺癌においてはM分画值の増加が強い.

\section{考察ならびに結語}

悪性腫瘍に括ける各血清蛋白成分の変動は当然, 抗腫 瘍剂, 輸血および外科的切除などの治療による影響, ま た合併症の有無および腫瘍の拡がりの程度により变化を 受けるが，同じ覀性腫演であってもその原因により，治 療の有無にかかわらず，薄層ゲル沪過分画像には一定の 傾向がみられる.すなわち，白血病では AML と ALL と では明らかに G分画值とM分画值に差がみられ， $\mathrm{AML}$ では両分画の増加がみられる．また悪性リンパ腫におい てあ，ホジキン病では $\mathrm{G}$ 分画值およびM分画值の増加が みられるが, 細網肉腫やリンパ肉腫ではての両分画はま ず増加がみられない，また総蛋白量もホジキン病では正 常値内であるが，その他の疾患では低值となる傾向が強 い. 癌腫に扰いてはへパトーマ, 胃癌, 結腸癌など消化 器系原発癌に扝いて総蛋白量や $\mathrm{A}$ 分画值の減少および $\mathrm{G}$ 分画值の増加が目立ち，また肺癌においては特にM分画 值の増加が著明である，癌の肝転移の有無との関係では (Fig. 5.), 転移例で $\mathrm{A}$ 分画值の減少と $\mathrm{G}$ 分画值の増加が軽 度であることは，赤井ら ${ }^{2)}$ のいう $\alpha$ 分画の増加は予後不 良を, $\gamma$ 分画の増加は長期生存の証拠であるという所見 をうらづけているようである.しかしての変動について は経時的に症例を追求して検討しなければならない。

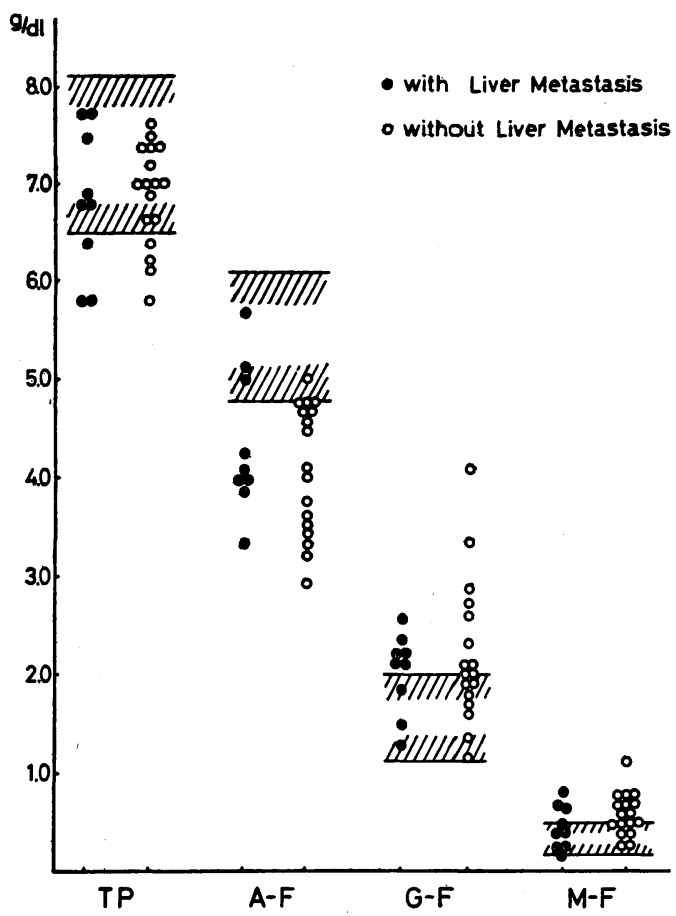

Fig. 5. Serum protein fractionation in carcinomas with and without liver metastasis, by using the thinlayer gel filtration technique.

文献

1) 河合 忠, 他: 生物物理化学, 13, 213 (1968).

2）赤井貞彦，吉田奎介：最新医学，23，1709 (1969).

32. 肺結核患者における喀痰及び血清の蛋 白分画について

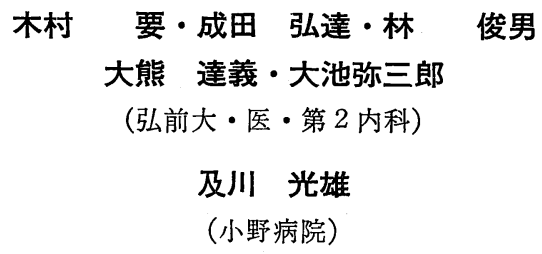

近年各種呼吸器疾患におりる喀痰の蛋白分画について 追求され，その臨床的応用が行なわれつつあるが，肺結 核患者についての研究は少なく, その臨床的関連につい ての追求は，きわめて少ない。

今回我々は, 肺結核患者について, その喀痰の蛋白分 画を電気泳動法によって追求しさらにてれと血清蛋白分 画との関係を検討した.

方法としては, NTA 分類による中等度進展及び高度 
進展の肺結核患者 62 名を対象に行なわれたが，そのう ち排菌者は 20 名, 非排菌者は 42 名であった。

早期起床時に，数回のうがいをさせた後に得られた喀 痰の約 $0.5 \mathrm{cc}$ を取り，乙れ等量の buffer $(0.1 \mathrm{M}$ クエ ン酸 $+0.2 \mathrm{M}$ 燐酸 1 水素ナトリウム, $\mathrm{pH} 7.0)$ を加えて 擋拌溶解させ，その $0.01 \mathrm{cc}$ を Separax に型の様に塗布 した.

常光産業 K.K., Type PAN-50 泳動装置を用い,

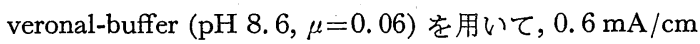
で 90 分間泳動を行なった.

泳動終了後は，ポンソー $3 \mathrm{R}$ にて蛋白染色を行ない， デンシトメーターによって吸光度を測定し，てれによっ て各分画の比率を求めた．血清蛋白についての泳動も同 様にして行なわれた。

喀痰の電気泳動においては, 泳動する 4 つの分画, つ まり alb, $\alpha-, \beta-, \gamma$-glob 之原点に残る分画が認められた。 これらのうち,移動する常在分画は, alb および $\gamma$-glob であった。

一般に培養 $(+)$ の喀痰に拈いては, alb 分画が高く なる傾向にあり,一方培養(一)の喀痰においては, $\gamma$-glob 分画が高くなる傾向にあった。との事より alb $/ \gamma$-glob 比を見ると, 培養 $(-)$ の group の平均值は 0.45 , 培 楸（十）の group は 0.78 とあきらかに有意の差を示し た.

血清に求ける alb $/ \gamma$-glob 比は, 非排菌者では 2.20 , 排菌者では 2.04 であった.

次ぎに，喀痰の $\mathrm{alb} / \gamma$-glob 比と血清のそれとは，排 菌者では逆相関 $(\mathrm{r}=-0.65)$ を示し, 非排菌者において は何らの相関 $(r=0.18)$ をも示さなかった．との事は活 動性肺結核に扰いては, 肺胞壁を通して血清の alb が漏 出され喀痰として排出される可能性を示す.

血清における alb $/ \gamma$-glob 比と血沈との関係を見ると， 排菌者及び非排菌者において負の相関，つまり $\mathrm{alb} / \mathrm{r}$ glob 比が低くなればなる程血沈值が高くなる傾向にあ

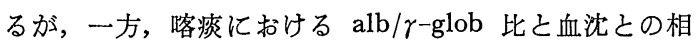
関を見ると，非排菌者においては負の傾向を示すが，排 菌者においては正の傾向を示した。

以上, 肺結核患者における喀疢の電気泳動による蛋白 分画には，排菌者及び非排菌者でかなり異なった泳動 pattern を示す傾向がある. Alb $/ \gamma$-glob 比は肺結核の 活動性のときに大きく, 又活動性肺結核では, 血清の alb $/ \gamma$-glob 比住対して負の相関関係を示す事が認めら れた.

\section{3. 血清蛋白分画による病勢判定の試み 一肺結核患者を中心にして——}

今井 昌雄

（国療・東名古屋病院）

治療医学の発達と共に, 病名の診断だけでなく病勢 (即 ち condition of patient) 診断, 治療的診断の必要性が增 加している. これは特に慢性感染症, 悪性腫瑒, 老人病 の臨床において感じられるが，肺結核の場合も高令患者 の増加, 耐性菌の出現, 肝障害, 腎障害, 腫崵の合併な ぞによって，現在の病勢をどう解釈したらよいかの問題 亿遭遇するととが多い，血清蛋白は全身細胞を環流し乍 ら生体内環境を維持させる重要な体液因子であるが, 特 に血清蛋白分画は組になった 5 個の情報が 1 度に得られ る点からいっても, 生体内ホメオスタシスの状態を定量 的に表わすのに恰好なサンプルと考えられるので，肺結 核患者を母集団としてて病勢診断へのアブローチを行なっ た.

電気泳動は本学会の標準操作法によるセルロースアセ テート法(セパラックス)で行ない，デンシトメトリー法 (Lumicon P-2 A) によって蛋白分画測定を行なった. 肺 結核患者は NTA 分類に上る軽症 (185 例)，中等症 (304 例), 重症（182 例）及び正常（23 例）を対象にしたが， NTA 分類は余り細かい規定をしていない為, 却って色 々の要因や確率的変動を包括しており，臨床的にも他の 分類より使用し易く，化学療法の発達した現時点におい て1番良好な分類を示すからである. 勿論とのグループ 分けには蛋白に関する情報は全然使用されていない。

病気の状態を 5 個の数值の組で与えられる 5 次元空間 における 1 点と考え，その空間内での分布状態の特徽を 明らかにし，それらの分布状態を基にして病勢の目灾を あたえる特徵量を導入しようと試みた。統計学的に自然 な方法は共分散行列の固有ベクトルを座標軸にとる方法 と思われる. 5 次元の情報を 1 次元に落し最大の分散を 与える基ベクトルを計算したが，乙の方向に全サンプル 694 個が細長く分布している。 そてで蛋白分画の任意の 值 $\mathrm{x}=\left(\mathrm{x}_{1}, \mathrm{x}_{2}, \cdots, \mathrm{x}_{5}\right)$ 亿対して，その基ベクトル $\mathrm{e}_{1}$ 方向 成分を乗じたもの, 即ち

$$
\begin{aligned}
\mathrm{y} & =(0.813) \mathrm{alb} \%+(-0.065) \alpha_{1}-\mathrm{glob} \% \\
& +(-0.139) \alpha_{2}-\mathrm{glob} \%+(-0.0526) \beta \text {-glob } \% \\
& +(-0.560) \gamma \text {-glob } \%
\end{aligned}
$$

を進行度 $\mathrm{y}$ とよび肺結核の病勢の程度をあらわす測度と 規定した（との間の複雑な数学的演算は名大電子工学科 の協力によるあのであり, 京大大型電子計算機センター を利用したが，詳細は“医用電子と生体工学” に発表し た). 
この推定を裹づける為に，全 694 例を進行度の順に並 べて正常群， NTA 各群の度数分布をとってその分布状 態を検討すると共に，アトランダムに選んだ肺結核患者 20 例について進行度 y の持つ意義について検討した。 即ち順位尺度 Rd (軽症 (1) 加ら重症 (20) までの順位) と yの相関関係，間隔尺度 yd （単なる準位でなく之に 或る規準によって定量的な間隔をむたせたもの）とyの 相関関係を検討した. この場合 $\mathrm{Rd}, \mathrm{yd}$ は蛋白情報以外 の医学的情報によって定めたものである. 次に医師の求 めた病勢の程度の評価に基づいて蛋白分画から進行度を 求める回帰直線を求め, それによる進行度 $\hat{y}$ 之前述の yを比較すると極めて良好な相関を示しており，ふたつ の進行度 $\mathrm{y}, \hat{\mathrm{y}}$ の間には医師の評価との一致の程度にお いて殆んど差はなく，yの有用性が推定された，更に個々 の症例について $\mathrm{y}$ の時間的変化と医学的な綜合的病状の 時間的変化の間にもかなりの一致が認められ，y の妥当 性と共にその時系列的な解析の必要性を考えさせた．尚 その結果をみると alb と進行度（y）の動きはかなりよく 似て就り，肺結核の場合進行を表わす第 1 近似の目安か 進行度 (y) であり，その近似の目安が albであるととあ 首肯される。勿論 $\mathrm{y}$ は $\mathrm{alb}$ 以外の分画とも相関しており, 特に $\alpha_{2}$-glob, $\gamma$-glob は大きく作用しているが，乙の検 討は 5 分画の量的比率だけに着目した議論であって，免 疫電気泳動其の他によって質的な分析の進んだ重要な分 画 $\left(\alpha_{1}\right.$-glob, $\alpha_{2}$-glob など)の情報がマスクされている事 は否定できず，yの意義を進展させる為には免疫泳動法 其の他の情報をどのような重みづけで多変量解析に組み 入れるかが問題となろう。

本研究は名大電子工学科 島脇純一郎助教授, 桑原耕 治氏の御協力によるあのである.

\section{文献}

1）富永喜久男ほか：感染症と血清蛋白，最新医学， 23-8, 1701 (1968).

2) 古川俊之ほか：多変量解析法の応用，綜合臨床， 17-11，2407 (1968).

3) 今井昌雄, 島脇純一郎ほか：血清蛋白分画の分布と 病勢の進行度について, 医用電子と生体工学（投 稿中).

\section{4. 血清リポ蛋白 Disc 泳動法に関する研} 究

\author{
和田 光夫 ・ 三瀬 淳一 \\ （山口大・医・第 2 内科） \\ 中村正二郎 \\ (山口大・医・生化学)
}

ヒト血清リポ蛋白の簡易かつ正確な泳動分析法を求める ととは重要である．との目的のために，アクリルアミド ゲルを支持体とする Ornstein-Davis の Disc 泳動法を血 清リポ蛋白の分析に応用するととを意図した.

方法

検討の方法は泳動支持体を構成する分離用ゲル，中間 ゲル，試料ゲル各溶液の成分構成を変化させ，それらが 泳動像に及ぼす効果を観察するととを骨子とした．Disc 泳動用の試薬は Ornstein-Davis の preprint 法に従って 調製した.リポ蛋白染色には Sudan Black B (SBB) の $0.1 \%$ ethylene glycol (EG) 溶液を McDonald らの手法 に従って調製したものを用いた。

\section{結果 と考察}

\section{1. 実験法についての検討}

分離用ゲル： $\mathrm{S}_{\beta}$ 位のリポ蛋白（ $\beta$ リポ蛋白）の易動 度は分離用ゲルのゲル濃度に関係し，濃度の低い程大で あった．泳動像の判定に適当なゲル濃度は約 $4.0 \%$ 以下 であると判断された． $\alpha_{\mathrm{L}}$ 位のリポ蛋白（ $\alpha$ リポ蛋白）

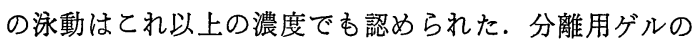
緩衝液濃度はリポ蛋白の易動度，とくに $\alpha$ リポ蛋白のそ れに影響し濃度の低い程易動度は大となった。リポ蛋白 を沪紙泳動によって分離し,泳動図から $\operatorname{pre} \beta$ 分画のみ を含むと確認し得た沪紙片の抽出液を用いて検討したと ころ, $\operatorname{pre} \beta$ リポ蛋白はゲル濃度 $3.4 \%$ 程度以上の分離 用ゲル層には殆んど進入せず同ゲル層の陰極端に止まる ことがわかった。しかし $3.0 \%$ の濃度では分離用ゲル層 に Disc を形成するととなく diffuse に進入した。

中間ゲル：上の結果にもとづき $3.75 \%$ の分離用ゲル を採用し,中間ゲル溶液について検討した. 中間ゲル溶液 として粗孔ゲル溶液をその儘用いても泳動像に変化を生 じないととを知り得た。検討の結果ではゲル濃度を $2.4 \sim 2.8 \%$ の範囲で変更してあ，また Stock E の割合 を粗孔ゲル溶液の $12.5 \%$ から $2.5 \%(1 / 5)$ に減じても泳 動像に変化を生じないととを確認した。ゲル濃度が低く なると（上記の範囲より）中間ゲル層の圧縮や変化がお とり，Stock E を更に減じるとゲル化が遅延した。 
試料量と染色法：前項に用いた分離用ゲルとゲル濃度 2.5\%，Stock E 2.5\%（v/v）とした中間ゲルを用い本 項の検討をした. Ressler らにならった $0.1 \% \mathrm{SBB}$ : 血 清=1：2(v/v) の使用量を変化させて観察した結果, 原血清 $4 \mu l$ であ泳動像の判読は不可能ではないが泳動 像の容易かつ正確な判読のためには $10 \mu l$ 以上 $20 \mu l$ 以 下が適当であろうと考えられた. Amidoblack による染 色を行なう場合には $5 \mu l$ が最大限であると考えられた. 染色法については SBB，血清混合後 24 時間〜数時間の あの, 直前混合のむの, 更にゲル管内混合などについて 検討したが，泳動像に差を認めなかった，ただし SBB 溶液の調製が完全であり試料量が過小でないととが前提 となると考えられた.

試料ゲル：上記の分離用ゲル，中間ゲルを用いゲル管 内混合染色を行なう方法によって本項の検討を行なった。 また SBB-EG 粗孔ゲル成分より成る系の性質を吟味す るために別の検討む行なった，粗孔ゲル溶液をその儘試 料ゲルとするととは不適当で, 組成を組み直す必要があ った. 主な理由は SBB とゲル溶液の混和にもとつく SBB の析出と SBB, 試料の添加によるゲル濃度の低下で ある. $0.1 \% \mathrm{SBB}$ - 余分の EG - 粗孔ゲル成分より成る 系について検討し, EG 総量対粗孔ゲル成分総和の比率 が大となる程 SBB の溶解のためには良くゲル化のため には良くないこと，比率が小となるとゲル化に良いが SBB の溶解には良くないという予想通りの結果を得た.

両面を兼備するものは比率 1.0 以下 0.6 以上であり，か つ $0.1 \% \mathrm{SBB}$ と添加する $\mathrm{EG}$ との割合が $5 \sim 8 \%(\mathrm{v} / \mathrm{v})$ とされたあのであると考えられた. 比率 $0.8 \sim 0.6$ の範 囲で検討した結果では試料ゲルのゲル濃度は $3.0 \%$ 以下 では不適当であると判断された（不可能という意味では ない).試料ゲル濃度 $2.6 \%$ 3.8\% の範囲では分離用ゲ ル層の蛋白泳動像に本質的な差は認められない. しかし 試料ゲル層は $3.0 \%$ 以下の濃度では well formed のもの とならず泳動中に膨化や断裂を生じるのが観察された. ゲル濃度 $2.4 \%$ のものではリポ蛋白, $\mathrm{AB}-10 \mathrm{~B}$ 像とも 他のむのと可なり異なった像を与えるととが観察された. 上記の結果を参考にしてゲル濃度 $3.3 \%$, 先述の比率 0.64 , Stock E の割合 $3.3 \%(\mathrm{v} / \mathrm{v}), 0.1 \% \mathrm{SBB}$ をG で 稀釈して $6.8 \%(\mathrm{v} / \mathrm{v})$ とした染色液使用液を用い, $\mathrm{SBB}$ 稀釈液とゲル溶液の混和は使用時に行なう.との方 法によって調製したものを採用して次の検討に進んだ.

2. 沪紙法との対比と汇紙泳動分画による Disc 泳

動分離縞の同定

上記各項で採用を決めたゲル溶液によって作成した泳 動ゲル系を用いて血清リポ蛋白の再現性のよい分析が容 易に可能であるととを確認し得た. 臨床例約 90 例, 健
常者約 140 例についてリポ蛋白沪紙泳動, 脂質化学分析, リポ蛋白 Disc 電気泳動を実施して確認したあのである. Disc 泳動分画の同定を兼ねた汇紙法との対比観察は

Paper electrophoresis

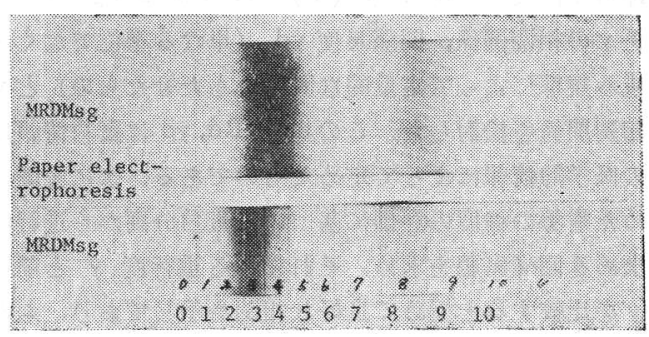

Disc electrophoresis

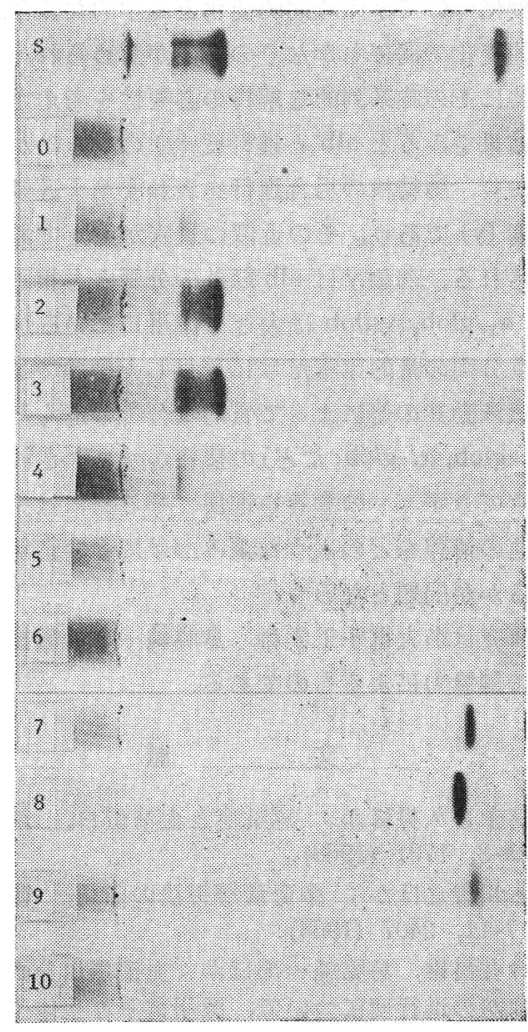

Fig. 1. Paper and disc electrophoresis of serum lipoprotein, a comparative study (case MRDsgr).

Protein fractions were extracted from the numbered pieces of paper ( 0 to $10,5 \times 40 \mathrm{~mm}$ or $10 \times 40 \mathrm{~mm})$. Twenty five $\mu l$ of extracts $(0.25$ $\mathrm{m} l$ of water was used) was submitted to lipoprotein disc electrophoresis. Numbers on disc electrophoretogram correspond to those on paper electrophoretogram. "S" designates combined extracts. 


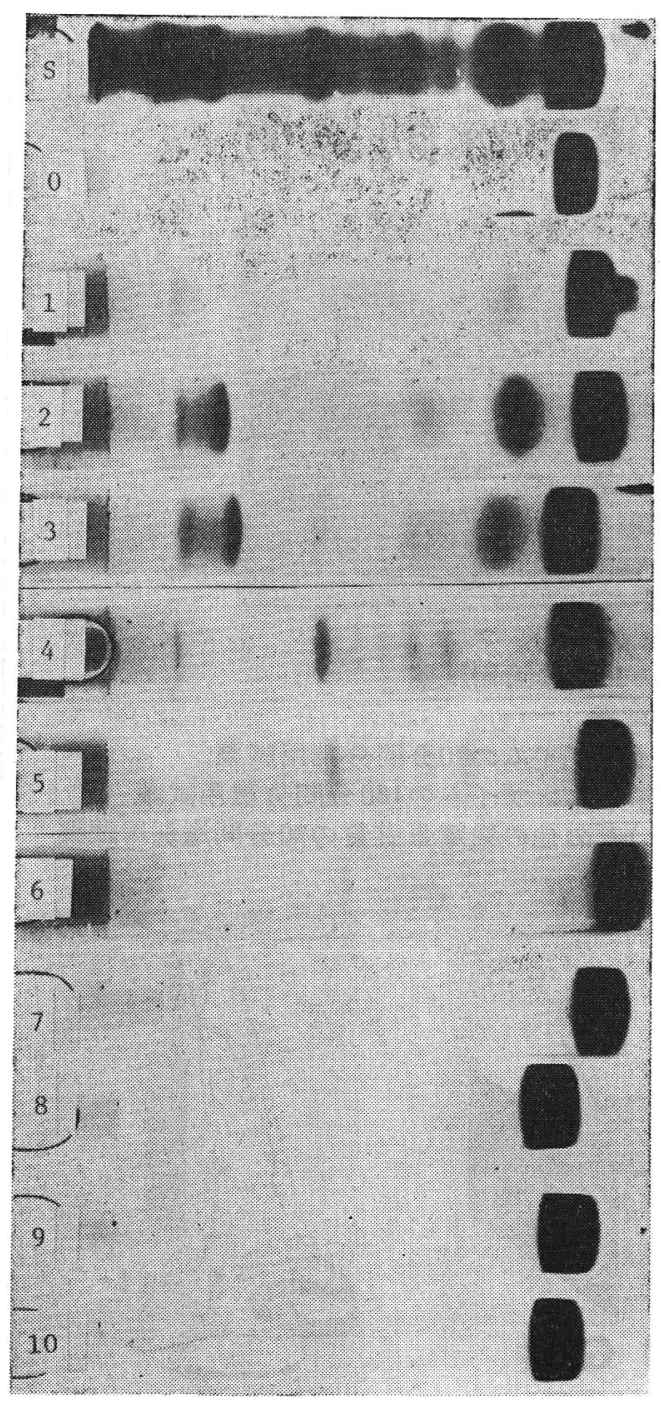

Fig. 2. Amidoblack 10B stained electrophoretogram of the extracted fractions (case MRDsgr).

Gels shown in Fig. 1. were stained by $\mathrm{AB} 10 \mathrm{~B}$ immediately after lipoprotein electrophoresis. Bovine serum albumin (Fraction V, Armour) was included in the extracts, because albuminated barbiturate buffer was used in paper electrophoresis.
概略次のようにして行なった. 幅 $6 \mathrm{~cm}$ の汇紙（Whatman $3 \mathrm{MM}$ ) 飞泳動方向飞直角飞 $5 \mathrm{~mm}$ 扣よび $10 \mathrm{~mm}$ の線を入れ，また長軸方向化線を引いて $4 \mathrm{~cm}$ 幅と $2 \mathrm{~cm}$ 幅の 2 枚に分割できるようにしておく、汇紙幅 $1 \mathrm{~cm}$ あ たり $20 \mu l$ の血清を原点飞塗布する. 泳動終了後速加に, 線に沿って切断し $2 \mathrm{~cm}$ 幅のものは Oil Red O による染 色に, 5 あるいは $10 \mathrm{~mm}$ の汇紙片は小試験管に入れて $0.25 \sim 0.50 \mathrm{ml}$ の蒸溜水での抽出に用いる. 24 時間以上 を経た $\left(4^{\circ} \mathrm{C}\right.$ 亿置く) 抽出液の $25 \mu l$ を用いて Disc 泳 動を行ないリポ蛋白像を観察したのち $\mathrm{AB}-10 \mathrm{~B}$ 染色を 行なう。

沪紙泳動上の $\alpha$ リポ蛋白は Disc 泳動では $\alpha_{\mathrm{L}}$ 位のリ ポ蛋白 (SBB 帯) と一致する. 汇紙泳動上の $\beta$ リポ蛋 白は Disc 泳動では $\mathrm{S}_{\beta}$ 位のリポ蛋白と一致するが殆ん どの場合 pre $\beta$ リポ蛋白の混入があるととが明らかに された. 沪紙泳動上の pre $\beta$ リポ蛋白は Disc 泳動では, 原理的当然のととであるが， $\beta$ 帯のうしろ（いわば post $\beta$ lipoprotein という関係をとる) 亿認められる. この分画は沪紙の上では pre $\beta$ の先進端から原点にか けて広く分布するととが, Disc 泳動によって明白に示 される。

$$
\text { ま と め }
$$

Ornstein-Davis の方法を基礎にして血清リポ蛋白の簡 易かつ正確な分析を可能にする Disc 泳動の 1 法を考案 した. 